\title{
Review \\ Magnetic Adsorbents for Wastewater Treatment: Advancements in Their Synthesis Methods
}

\author{
Vanpaseuth Phouthavong ${ }^{1}$, Ruixin Yan ${ }^{2}$, Supinya Nijpanich ${ }^{1}$, Takeshi Hagio ${ }^{1,3}$ (D) Ryoichi Ichino ${ }^{1,3, *}$, \\ Long Kong ${ }^{2, *}$ and Liang $\mathrm{Li}^{2}$
}

1 Department of Chemical Systems Engineering, Graduate School of Engineering, Nagoya University, Furo-cho, Chikusa-ku, Nagoya 464-8603, Japan; phouthavong.vanpaseuth@i.mbox.nagoya-u.ac.jp (V.P.); supinya@slri.or.th (S.N.); hagio@mirai.nagoya-u.ac.jp (T.H.)

2 School of Environmental Science and Engineering, Shanghai Jiao Tong University, Shanghai 200240, China; risonforever2018@gmail.com (R.Y.); liangli117@sjtu.edu.cn (L.L.)

3 Institute of Materials Innovation, Institutes for Innovation for Future Society, Nagoya University, Furo-cho, Chikusa-ku, Nagoya 464-8601, Japan

* Correspondence: ichino.ryoichi@material.nagoya-u.ac.jp (R.I.); longmao88@sjtu.edu.cn (L.K.)

\section{check for}

updates

Citation: Phouthavong, V.; Yan, R.;

Nijpanich, S.; Hagio, T.; Ichino, R.;

Kong, L.; Li, L. Magnetic Adsorbents for Wastewater Treatment:

Advancements in Their Synthesis

Methods. Materials 2022, 15, 1053.

https://doi.org/10.3390/

ma15031053

Academic Editors: Yoshikazu Todaka Hideyuki Kanematsu and

Takaya Sato

Received: 29 November 2021

Accepted: 25 January 2022

Published: 29 January 2022

Publisher's Note: MDPI stays neutral with regard to jurisdictional claims in published maps and institutional affiliations.

Copyright: (c) 2022 by the authors. Licensee MDPI, Basel, Switzerland. This article is an open access article distributed under the terms and conditions of the Creative Commons Attribution (CC BY) license (https:// creativecommons.org/licenses/by/ $4.0 /)$.

\begin{abstract}
The remediation of water streams, polluted by various substances, is important for realizing a sustainable future. Magnetic adsorbents are promising materials for wastewater treatment. Although numerous techniques have been developed for the preparation of magnetic adsorbents, with effective adsorption performance, reviews that focus on the synthesis methods of magnetic adsorbents for wastewater treatment and their material structures have not been reported. In this review, advancements in the synthesis methods of magnetic adsorbents for the removal of substances from water streams has been comprehensively summarized and discussed. Generally, the synthesis methods are categorized into five groups, as follows: direct use of magnetic particles as adsorbents, attachment of pre-prepared adsorbents and pre-prepared magnetic particles, synthesis of magnetic particles on pre-prepared adsorbents, synthesis of adsorbents on preprepared magnetic particles, and co-synthesis of adsorbents and magnetic particles. The main improvements in the advanced methods involved making the conventional synthesis a less energy intensive, more efficient, and simpler process, while maintaining or increasing the adsorption performance. The key challenges, such as the enhancement of the adsorption performance of materials and the design of sophisticated material structures, are discussed as well.
\end{abstract}

Keywords: magnetic adsorbent; synthesis methods; material structure; water treatment

\section{Introduction}

\subsection{Importance and Advantage of Magnetic Adsorbent Technologies for Wastewater Treatment}

Natural water sources, apart from soil and air, are the primary medium for pollutant mobility. Over the decades, the release of untreated wastewater into natural water sources, coupled with an ever-increasing population, has resulted in severe environmental problems. Enormous quantities of chemicals, such as pesticides, antibiotics, heavy metals, and dyes are used each year, to drive the global economy. As clean water sources are limited, wastewater should be recycled, by utilizing effective chemical, physical, and biological treatment technologies. Among these techniques, adsorption is a widely exploited physical method because it is simple, environmentally friendly, cost-effective, and reusable [1]. Adsorbents used for the removal of pollutants can be developed to selectively adsorb target adsorbates, with high adsorption performance. The collection of adsorbents after adsorption should be quick and easy. The magnetic separation technique is a good option because magnetic materials can be separated easily from mixtures by applying a magnetic field. The first application of magnetic separation [2] was reported by Robinson et al. [3], in 1973 , for the separation of enzymes immobilized on the surface of iron oxide particles. Since 
then, the application of magnetic separation in adsorption has been extended in different ways, described below:

(i) Addition of magnetic particles (iron ( $\mathrm{Fe})$ or iron oxides $\left(\mathrm{Fe}_{\mathrm{x}} \mathrm{O}_{\mathrm{y}}\right)$ ) to assist in the separation of precipitates; that is, coagulation-flocculation during the water treatment process [4,5];

(ii) Direct use of magnetic materials as adsorbents [6];

(iii) Combining magnetic particles with adsorbents to yield magnetic adsorbents [7].

The latter two alternatives have received more interest. Keyword searches in Scopus for "magnetic + adsorbent + separation" and "magnetic + adsorbent + water treatment", reveal a growing trend in the number of research articles (Figure 1).

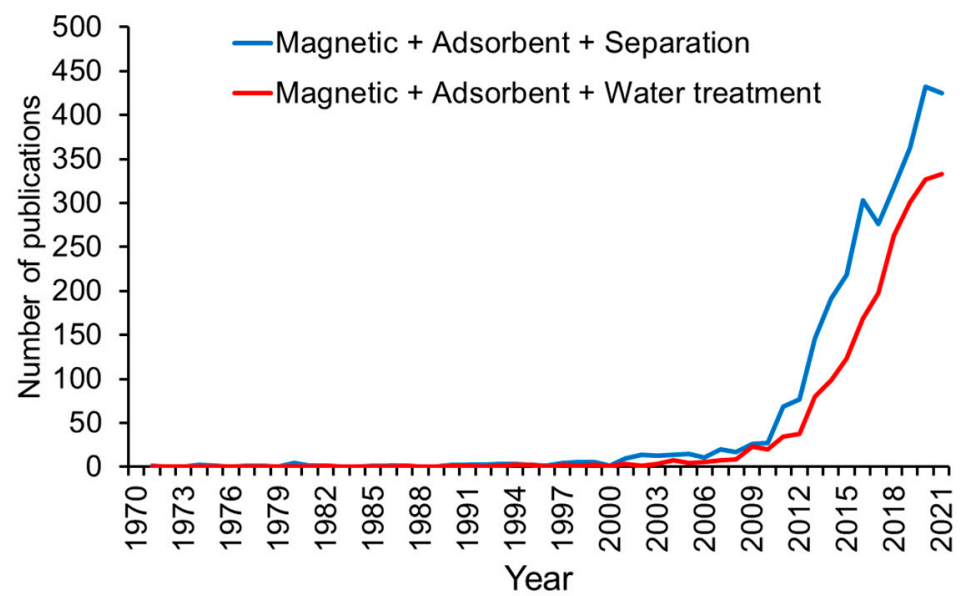

Figure 1. Number of publications that contain the keywords "magnetic + adsorbent + separation" and "magnetic + adsorbent + water treatment" in Scopus. (Accessed on 2 January 2022).

\subsection{History and Advancements of Magnetic Adsorbents}

Iron-based materials are typically used as magnetic particles because of the strong magnetic moment of unpaired electrons in the 3D orbitals of Fe atoms. The most commonly used materials in the adsorption process are magnetic materials, such as Fe, magnetite $\left(\mathrm{Fe}_{3} \mathrm{O}_{4}\right)$, and maghemite $\left(\gamma-\mathrm{Fe}_{2} \mathrm{O}_{3}\right)$. Though $\mathrm{Fe}$ and $\mathrm{Fe}_{3} \mathrm{O}_{4}$ exhibit strong responses to magnetic fields, $\mathrm{Fe}_{3} \mathrm{O}_{4}$ is used most widely in the literature, owing to its higher stability. $\mathrm{Fe}_{3} \mathrm{O}_{4}$ particles are superparamagnetic at a size of several nanometers [8]. In aqueous solutions, the abundant hydroxyl groups on the surface of $\mathrm{Fe}_{3} \mathrm{O}_{4}$ can be protonated or deprotonated by varying the $\mathrm{pH}$, to generate positive or negative charges. Therefore, $\mathrm{Fe}_{3} \mathrm{O}_{4}$ can be used as an adsorbent to remove ionic species from water via electrostatic interactions [9]. The Fe atom in $\mathrm{Fe}_{3} \mathrm{O}_{4}$ also acts as an adsorption site for complexation with negatively charged species or the electron-rich functional groups of some organic pollutants. Further, the surface of $\mathrm{Fe}_{3} \mathrm{O}_{4}$ can be modified to improve functionalization and protect the magnetic core from magnetism degradation [10]. Magnetic adsorbents offer the following advantages:

(i) They can be easily separated from bulk solutions by applying an external magnetic field;

(ii) They are environmentally friendly owing to their biocompatibility [11];

(iii) They are reusable;

(iv) Various organic and inorganic functional groups, to remove diverse target pollutants, can be prepared and modified at the laboratory scale.

In addition to environmental remediation applications, magnetic adsorbents have been used in analytical chemistry in the so-called magnetic solid-phase extraction sample preparation technique. This technique is used to clean up and pre-concentrate the samples, before core analysis improves the detection of anions [12] and organic pollutants [13]. 
Although magnetic iron oxides are naturally occurring, we can control particle size and achieve better purity by synthesizing them in the laboratory via various routes, such as co-precipitation [14], hydrothermal [15], solvothermal [16], thermal decomposition [17], microemulsion [18], electrochemical [19], and microwave-assisted [20] methods, and greener synthesis methods using biogenic materials [21,22]. Functionalized magnetic particles, or magnetic composites, have been developed or modified using these methods. Among these methods, co-precipitation is the most widely used, due to its simple operation at low temperatures. However, the affinity of hydroxy groups on conventional magnetic iron oxides limits the adsorption performance of some target cationic species. Consequently, they have been coupled with functional adsorbents, such as polymeric ion-exchange resins, used in water treatment processes $[23,24]$. The magnetic polymer, prepared by the polymerization of $\gamma-\mathrm{Fe}_{2} \mathrm{O}_{3}$, is useful for water softening, desalinization, and oil removal from water. In 1996, Chen et al. [25] prepared magnetic composites by simply precipitating ferrihydrite $\left(\mathrm{Fe}(\mathrm{OH})_{3}\right)$ from $\mathrm{Fe}_{3} \mathrm{O}_{4}$ and used it to remove heavy metals from water. Since then, the synthesis of magnetic adsorbents has drawn considerable attention, as indicated by the growing number of publications. Diverse effective adsorbents have been reported to incorporate magnetic particles, such as metal oxides [26,27], silica-based materials [28-32], carbon-based materials [33-35], graphene oxide [36], biopolymers, such as lignin [37], cellulose [38], chitosan [39], synthetic polymers [40-42], molecularly imprinted polymers [43], metal organic frameworks [44], and biowaste [45,46]. Magnetic adsorbents can be prepared using physical methods, such as mechanical agitation (stirring, vibration, milling, and ultrasonication) at room or elevated temperatures in some cases, along with the addition of adhesives. Examples of these physical attachments are discussed concretely in this review. Although magnetic adsorbents prepared by physical methods show reasonable adsorption performance, the loose attachment results in a deterioration of their morphology. A low adsorption performance could be due to hidden adsorption sites attaching to the magnetic particles. In contrast, chemically bonded magnetic adsorbents can overcome these drawbacks. Conventional chemical methods utilize specific chemical reactions to form magnetic particles, on pre-synthesized adsorbents or adsorbents on magnetic particles under certain treatment conditions, such as hydrothermal, solvothermal, or reflux.

The adsorption performance of $\mathrm{Fe}_{3} \mathrm{O}_{4}$ can be improved by doping with sulfur $[47,48]$. This technology has also been applied to composite adsorbents; namely, converting the $\mathrm{Fe}_{3} \mathrm{O}_{4}$ priorly embedded onto adsorbents to $\mathrm{Fe}_{3} \mathrm{~S}_{4}$ [49]. The challenge in magnetic adsorbent synthesis is not only to improve the adsorption performance, but also to accomplish good distribution or incorporation of magnetic particles in the adsorbent morphology. Advanced synthesis routes, such as the seed-assisted method [29], pre-milling of magnetic particles with adsorbent seed crystals [30], embedding magnetic particles with a carbon source before carbonization [34], or pre-attaching magnetic particles with precursors as a dry gel before heat treatment [31], help to improve the morphology of magnetic adsorbents. Furthermore, challenges to co-synthesizing magnetic particles and adsorbents in a one-pot synthesis have recently been explored [26].

\subsection{Previous Reviews}

Many review papers have been published about magnetic particles (not magnetic adsorbents), based on different perspectives, such as the type of surface coating materials, phase of synthesis media, type of reactor, and potential applications. In the area of catalysts and medicine, Lu et al. [10] and Wu et al. [8] classified the synthesis methods of magnetic materials into four popular methods; namely, co-precipitation, thermal decomposition, microemulsion, and hydrothermal synthesis, and also reviewed the surface modification of magnetic particles, based on the type of coating materials. In addition, Teja et al. [50] summarized the synthesis methods of iron oxides and categorized them, according to phase of synthesis media, such as gas phase, liquid phase, and two-phase methods, for the same scientific area. Synthesis methods of magnetic particles, sub-divided using more specific terminology, were found in some review articles [51,52]. Akbarzadeh et al. [53] 
focused on magnetic particles for biomedicines. Ali et al. [52] comprehensively summarized and discussed various applications for magnetic materials, for industrial, biomedical, environmental, agricultural, and analytical purposes. Ali's group introduced applications for wastewater treatment briefly, in the section for environmental application. Recently, García-Merino et al. [54] reviewed the synthesis of magnetic particles based on types of reactors. They summarized and compared features of conventional batch synthesis with continuous microfluidic synthesis methods. It was found that most of the above reviews focus on the classification of treatment processes, such as physical, chemical, or biological methods. The relationship between synthesis methods and performance in wastewater treatment has seldom been studied.

As for magnetic adsorbents, Reshadi et al. [55] reviewed magnetic adsorbents used for landfill leachate treatment. Furthermore, magnetic adsorbents for wastewater treatment have been reported by Shukla et al. [56], from the viewpoint of the synthesis methods of magnetic nanoparticles. Abdullah et al. [57] summarized research articles, regarding the synthesis of magnetic adsorbents that used conventional methods, but mainly focused on various types of solid substrates, which were common adsorbents, such as silica-based materials, carbon materials, and graphene, to embed the magnetic particles. Apart from synthesis methods, magnetic adsorbents have been reviewed from another point of view. Abdel Maksoud et al. [58] presented the advantages of using magnetic adsorbents, by classifying them based on types of applied magnetic materials. They additionally discussed their properties and removal efficiency towards organic and inorganic pollutants.

\subsection{Objective of This Review}

As summarized above, numerous techniques have been developed for the preparation of magnetic adsorbents with effective adsorption performance. To date, magnetic adsorbents have been reviewed from different perspectives; however, reviews that focus on the synthesis methods and the obtained material structures have not been reported. In this review, magnetic adsorbents, mostly used for water pollutant removal, are reviewed and classified by focusing on the synthesis method and the attaching force between magnetic materials and adsorbents, within the obtained material structure. The advantages and drawbacks of these methods, together with the magnetic properties and adsorption performance of the materials, are discussed. Additionally, research papers that illustrate the advancement of each category are summarized.

\section{Conventional Synthesis Methods of Magnetic Adsorbents}

Conventional synthesis methods can be categorized into four primary groups. Conventional magnetic adsorbents used for the removal of various organic and inorganic pollutants from water, according to their groups with their synthesis methods, adsorption performances, and magnetic performances, are summarized in Table 1.

Table 1. Magnetic adsorbents, their conventional synthesis routes, and performance on adsorption of organic and inorganic pollutants in water.

\begin{tabular}{|c|c|c|c|c|c|}
\hline Adsorbents & Synthesis Method & Magnetic Properties & Pollutant(s) & $\begin{array}{l}\text { Adsorption or } \\
\text { Removal Performance }\end{array}$ & Reference \\
\hline \multicolumn{6}{|c|}{ Magnetic materials as adsorbents } \\
\hline Microsized Fe & Commercial & $\mathrm{M}_{\mathrm{s}}=1725 \mathrm{kA} / \mathrm{m}$ & Phosphate & $\mathrm{q}_{\mathrm{m}}=18.83 \mathrm{mg} / \mathrm{g}$ & [59] \\
\hline Nanosized $\mathrm{Fe}_{3} \mathrm{O}_{4}$ & $\begin{array}{l}\text { Sol-gel precipitation and } \\
\text { re-crystallization }\end{array}$ & $\mathrm{M}_{\mathrm{s}}=477 \mathrm{kA} / \mathrm{m}$ & Phosphate & $\mathrm{q}_{\mathrm{m}}=27.15 \mathrm{mg} / \mathrm{g}$ & [59] \\
\hline $\mathrm{Fe}_{3} \mathrm{O}_{4}$ & Ferrite process & Not reported & Phosphate & \multirow{3}{*}{$\begin{array}{l}\mathrm{q}_{\mathrm{m}}=1.9-3.7 \mathrm{mg} / \mathrm{g} \\
\mathrm{q}_{\mathrm{m}}=15.2 \mathrm{mg} / \mathrm{g} \\
\text { Removal efficiency } \\
>95 \%\end{array}$} & [15] \\
\hline $\mathrm{Fe}_{3} \mathrm{O}_{4}$ & Co-precipitation & Not reported & Phosphate & & [60] \\
\hline $\begin{array}{l}\text { Mixed } \mathrm{Fe}_{3} \mathrm{O}_{4} \text { and } \\
\gamma-\mathrm{Fe}_{2} \mathrm{O}_{3}\end{array}$ & Microemulsion & Not reported & Phosphate & & [18] \\
\hline
\end{tabular}


Table 1. Cont.

\begin{tabular}{|c|c|c|c|c|c|}
\hline Adsorbents & Synthesis Method & Magnetic Properties & Pollutant(s) & $\begin{array}{l}\text { Adsorption or } \\
\text { Removal Performance }\end{array}$ & Reference \\
\hline $\begin{array}{l}\text { Mixed } \alpha-\mathrm{Fe}_{2} \mathrm{O}_{3} \text { and } \\
\gamma-\mathrm{Fe}_{2} \mathrm{O}_{3}\end{array}$ & Dispersion-precipitation & $\mathrm{M}_{\mathrm{s}}=20 \mathrm{emu} / \mathrm{g}$ & Arsenite & $\mathrm{q}_{\mathrm{m}}=46.5 \mathrm{mg} / \mathrm{g}$ & {$[61]$} \\
\hline $\mathrm{Fe}_{3} \mathrm{O}_{4}$ & $\begin{array}{l}\text { Simple mixing and } \\
\text { sintering }\end{array}$ & $\mathrm{M}_{\mathrm{S}}=57.4 \mathrm{emu} / \mathrm{g}$ & $\mathrm{As}(\mathrm{V})$ & $\mathrm{q}_{\mathrm{m}}=20.24 \mathrm{mg} / \mathrm{g}$ & {$[48]$} \\
\hline $\mathrm{Fe}_{3} \mathrm{O}_{4}$ & Co-precipitation & $\mathrm{M}_{\mathrm{s}}=56.86 \mathrm{emu} / \mathrm{g}$ & $\mathrm{As}(\mathrm{V})$ & $\mathrm{q}_{\mathrm{m}}=44.99 \mathrm{mg} / \mathrm{g}$ & {$[62]$} \\
\hline $\begin{array}{l}\text { Mixed } \mathrm{Fe}_{3} \mathrm{O}_{4} \text { and } \\
\gamma-\mathrm{Fe}_{2} \mathrm{O}_{3}\end{array}$ & Co-precipitation & $\mathrm{M}_{\mathrm{s}}=67 \mathrm{emu} / \mathrm{g}$ & $\begin{array}{l}\mathrm{Pb}(\mathrm{II}) \\
\mathrm{Cr}(\mathrm{III}) \\
\mathrm{Cd}(\mathrm{II}) \\
\mathrm{Co}(\mathrm{II})\end{array}$ & $\begin{array}{l}\mathrm{q}_{\mathrm{m}}=617.3 \mathrm{mg} / \mathrm{g} \\
\mathrm{q}_{\mathrm{m}}=277.0 \mathrm{mg} / \mathrm{g} \\
\mathrm{q}_{\mathrm{m}}=223.7 \mathrm{mg} / \mathrm{g} \\
\mathrm{q}_{\mathrm{m}}=27.44 \mathrm{mg} / \mathrm{g}\end{array}$ & {$[63]$} \\
\hline Biogenic $\mathrm{Fe}_{3} \mathrm{O}_{4}$ & $\begin{array}{l}\text { Fe3+-reducing bacterial } \\
\text { enrichment culture }\end{array}$ & Not reported & $\begin{array}{l}\mathrm{Ni}(\mathrm{II}) \\
\mathrm{Mn}(\mathrm{II}) \\
\mathrm{Zn}(\mathrm{II})\end{array}$ & $\begin{array}{l}\mathrm{q}_{\mathrm{m}}=25.22 \mathrm{mg} / \mathrm{g} \\
\mathrm{q}_{\mathrm{m}}=26.55 \mathrm{mg} / \mathrm{g} \\
\mathrm{q}_{\mathrm{m}}=77.27 \mathrm{mg} / \mathrm{g}\end{array}$ & {$[64]$} \\
\hline $\mathrm{Fe}_{3} \mathrm{O}_{4}$ & Co-precipitation & $\mathrm{M}_{\mathrm{s}}=65.33 \mathrm{emu} / \mathrm{g}$ & $\begin{array}{l}\mathrm{Pb}(\mathrm{II}) \\
\mathrm{Cr}(\mathrm{VI})\end{array}$ & $\begin{array}{l}\mathrm{q}_{\mathrm{m}}=53.11 \mathrm{mg} / \mathrm{g} \\
\mathrm{q}_{\mathrm{m}}=34.87 \mathrm{mg} / \mathrm{g}\end{array}$ & {$[65]$} \\
\hline \multicolumn{6}{|c|}{ Attaching of pre-synthesized magnetic particles with adsorbents } \\
\hline Clinoptilolite- $-\mathrm{Fe}_{3} \mathrm{O}_{4}$ & Mechanical method & Not reported & $\begin{array}{l}\mathrm{Cd}(\mathrm{II}) \\
\mathrm{Cu}(\mathrm{II}) \\
\mathrm{Pb}(\mathrm{II})\end{array}$ & $\begin{array}{l}\text { Removal efficiency } \\
=50 \% \\
\text { Removal efficiency } \\
=70 \% \\
\text { Removal efficiency } \\
=90 \%\end{array}$ & [66] \\
\hline Zeolite- $\mathrm{Fe}_{3} \mathrm{O}_{4}$ & Using organic adhesive & Not reported & $\mathrm{Pb}(\mathrm{II})$ & $\mathrm{q}_{\mathrm{m}}=133 \mathrm{mg} / \mathrm{g}$ & [67] \\
\hline Faujasite zeolite-CoFe ${ }_{2} \mathrm{O}_{4}$ & Ultrasonication & $\mathrm{M}_{\mathrm{s}}=18.93 \mathrm{emu} / \mathrm{g}$ & $\mathrm{Pb}(\mathrm{II})$ & $\begin{array}{l}\text { Removal efficiency = } \\
99 \%\end{array}$ & {$[68]$} \\
\hline Wheat stalk-derived chars- $\mathrm{Fe}_{3} \mathrm{O}_{4}$ & Simple mixing & $\mathrm{M}_{\mathrm{s}}=28.6 \mathrm{emu} / \mathrm{g}$ & $\mathrm{Pb}(\mathrm{II})$ & $\mathrm{q}_{\mathrm{m}}=179.85 \mathrm{mg} / \mathrm{g}$ & [35] \\
\hline Rice husk-derived chars- $\mathrm{Fe}_{3} \mathrm{O}_{4}$ & Simple mixing & $\mathrm{M}_{\mathrm{s}}=26.1 \mathrm{emu} / \mathrm{g}$ & $\mathrm{Pb}(\mathrm{II})$ & $\mathrm{q}_{\mathrm{m}}=95.44 \mathrm{mg} / \mathrm{g}$ & {$[35]$} \\
\hline Activated carbon- $\mathrm{Fe}_{3} \mathrm{O}_{4}$ & Simple mixing & $\mathrm{M}_{\mathrm{s}}=27.2 \mathrm{emu} / \mathrm{g}$ & $\mathrm{Pb}(\mathrm{II})$ & $\mathrm{q}_{\mathrm{m}}=43.38 \mathrm{mg} / \mathrm{g}$ & {$[35]$} \\
\hline Zeolite- $\mathrm{Fe}_{3} \mathrm{O}_{4}$ & Simple dispersion & Not reported & $\mathrm{Zn}(\mathrm{II})$ & $\mathrm{q}_{\mathrm{m}}=30 \mathrm{mg} / \mathrm{g}$ & {$[69]$} \\
\hline $\begin{array}{l}\mathrm{Na}-\mathrm{P} 1 \text { and } \\
\text { hydroxysodalite- }-\mathrm{Fe}_{3} \mathrm{O}_{4}\end{array}$ & Mechanical method & Not reported & $\mathrm{U}(\mathrm{VI})$ & $\mathrm{q}_{\mathrm{m}}=22.4 \mathrm{mg} / \mathrm{g}$ & {$[70]$} \\
\hline Kaolin-based zeolite $\mathrm{A}-\mathrm{Fe}_{3} \mathrm{O}_{4}$ & $\begin{array}{l}\text { Maceration and } \\
\text { dispersion }\end{array}$ & Ms»37.1 emu/g & $\mathrm{Ca}(\mathrm{II})$ & $\mathrm{q}_{\mathrm{m}}=54 \mathrm{mg} / \mathrm{g}$ & [71] \\
\hline Kaolin-based zeolite $\mathrm{P}-\mathrm{Fe}_{3} \mathrm{O}_{4}$ & $\begin{array}{l}\text { Maceration and } \\
\text { dispersion }\end{array}$ & Ms»37.1 emu/g & $\mathrm{Ca}(\mathrm{II})$ & $\mathrm{q}_{\mathrm{m}}=51 \mathrm{mg} / \mathrm{g}$ & [71] \\
\hline Zeolite-chitosan- $\mathrm{Fe}_{3} \mathrm{O}_{4}$ & Simple mixing & Not reported & $\mathrm{Cr}(\mathrm{VI})$ & $\begin{array}{l}\text { Removal efficiency } \\
=98 \%\end{array}$ & [72] \\
\hline $\begin{array}{l}\text { Thiol and amine functionalized } \\
\text { cellulose- }-\mathrm{Fe}_{3} \mathrm{O}_{4}\end{array}$ & Stirring & Not reported & $\mathrm{Pt}(\mathrm{IV})$ & $\mathrm{q}_{\mathrm{m}}=40.48 \mathrm{mg} / \mathrm{g}$ & [73] \\
\hline $\begin{array}{l}\text { Hydroxyapatite/chitosan } \\
\text { cross-linked with green tea } \\
\text { derived polyphenol- } \mathrm{Fe}_{3} \mathrm{O}_{4}\end{array}$ & Stirring & $\mathrm{M}_{\mathrm{s}}=53.6 \mathrm{emu} / \mathrm{g}$ & $\mathrm{Ni}(\mathrm{II})$ & $\mathrm{q}_{\mathrm{m}}=112.36 \mathrm{mg} / \mathrm{g}$ & [74] \\
\hline $\begin{array}{l}\text { Iminodiacetate functionalized } \\
\mathrm{PGMA}_{-} \mathrm{Fe}_{3} \mathrm{O}_{4}\end{array}$ & High-energy ball milling & $\mathrm{M}_{\mathrm{s}}=22.56 \mathrm{emu} / \mathrm{g}$ & Uranyl & $\mathrm{q}_{\mathrm{m}}=122.9 \mathrm{mg} / \mathrm{g}$ & {$[75]$} \\
\hline $\begin{array}{l}\text { Iminodiphosphonate } \\
\text { functionalized PGMA-Fe }{ }_{3} \mathrm{O}_{4} \\
\text { Phenol modified ZIF-8 }\end{array}$ & High-energy ball milling & $\mathrm{M}_{\mathrm{s}}=21.14 \mathrm{emu} / \mathrm{g}$ & Uranyl & $\mathrm{q}_{\mathrm{m}}=147.0 \mathrm{mg} / \mathrm{g}$ & [75] \\
\hline $\begin{array}{l}\text { functionalized carboxymethyl } \\
\text { cellulose- }-\mathrm{Fe}_{3} \mathrm{O}_{4}\end{array}$ & Ultrasonication & Not reported & $\mathrm{Rb}(\mathrm{I})$ & $\mathrm{q}_{\mathrm{m}}=109 \mathrm{mg} / \mathrm{g}$ & [76] \\
\hline [Epichlorohydrin-co- & & & $\mathrm{Pb}(\mathrm{II})$ & $\mathrm{q}_{\mathrm{m}}=293.38 \mathrm{mg} / \mathrm{g}$ & \\
\hline $\begin{array}{l}\text { triethylenetetramine }]_{n} \text {-graft- } \\
\mathrm{CSSNa}-\mathrm{Fe}_{3} \mathrm{O}_{4} \\
\text { microspheres }\end{array}$ & Ultrasonication & $\mathrm{M}_{\mathrm{s}}=50.51 \mathrm{emu} / \mathrm{g}$ & $\begin{array}{l}\mathrm{Cd}(\mathrm{II}) \\
\mathrm{Cu}(\mathrm{II}) \\
\mathrm{Zn}(\mathrm{II})\end{array}$ & $\begin{array}{l}\mathrm{q}_{\mathrm{m}}=256.69 \mathrm{mg} / \mathrm{g} \\
\mathrm{q}_{\mathrm{m}}=277.93 \mathrm{mg} / \mathrm{g} \\
\mathrm{q}_{\mathrm{m}}=225.07 \mathrm{mg} / \mathrm{g}\end{array}$ & {$[41]$} \\
\hline $\begin{array}{l}\text { NiAl LDH-guar gum } \\
\text { polymer-Fe }{ }_{3} \mathrm{O}_{4}\end{array}$ & Ultrasonication & Not reported & $\mathrm{Cr}(\mathrm{VI})$ & $\mathrm{q}_{\mathrm{m}}=101 \mathrm{mg} / \mathrm{g}$ & [77] \\
\hline $\mathrm{MgAl} \mathrm{LDH}-\mathrm{Fe}_{3} \mathrm{O}_{4}$ & Ultrasonication & Not reported & Congo red & $\mathrm{qm}_{\mathrm{m}}=505 \mathrm{mg} / \mathrm{g}$ & {$[78]$} \\
\hline Graphene oxide- $-\mathrm{Fe}_{3} \mathrm{O}_{4}$ & Liquid-self assembly & $\mathrm{M}_{\mathrm{s}}=18.2 \mathrm{emu} / \mathrm{g}$ & $\begin{array}{l}\text { Methylene } \\
\text { blue }\end{array}$ & $\mathrm{q}_{\mathrm{m}}=172.6 \mathrm{mg} / \mathrm{g}$ & [36] \\
\hline Activated carbon- $\mathrm{Fe}_{3} \mathrm{O}_{4}$ & Ball milling & $\mathrm{M}_{\mathrm{s}}=33.8 \mathrm{emu} / \mathrm{g}$ & $\begin{array}{l}\text { Methylene } \\
\text { blue }\end{array}$ & $\mathrm{q}_{\mathrm{m}}=500.5 \mathrm{mg} / \mathrm{g}$ & {$[36]$} \\
\hline
\end{tabular}


Table 1. Cont.

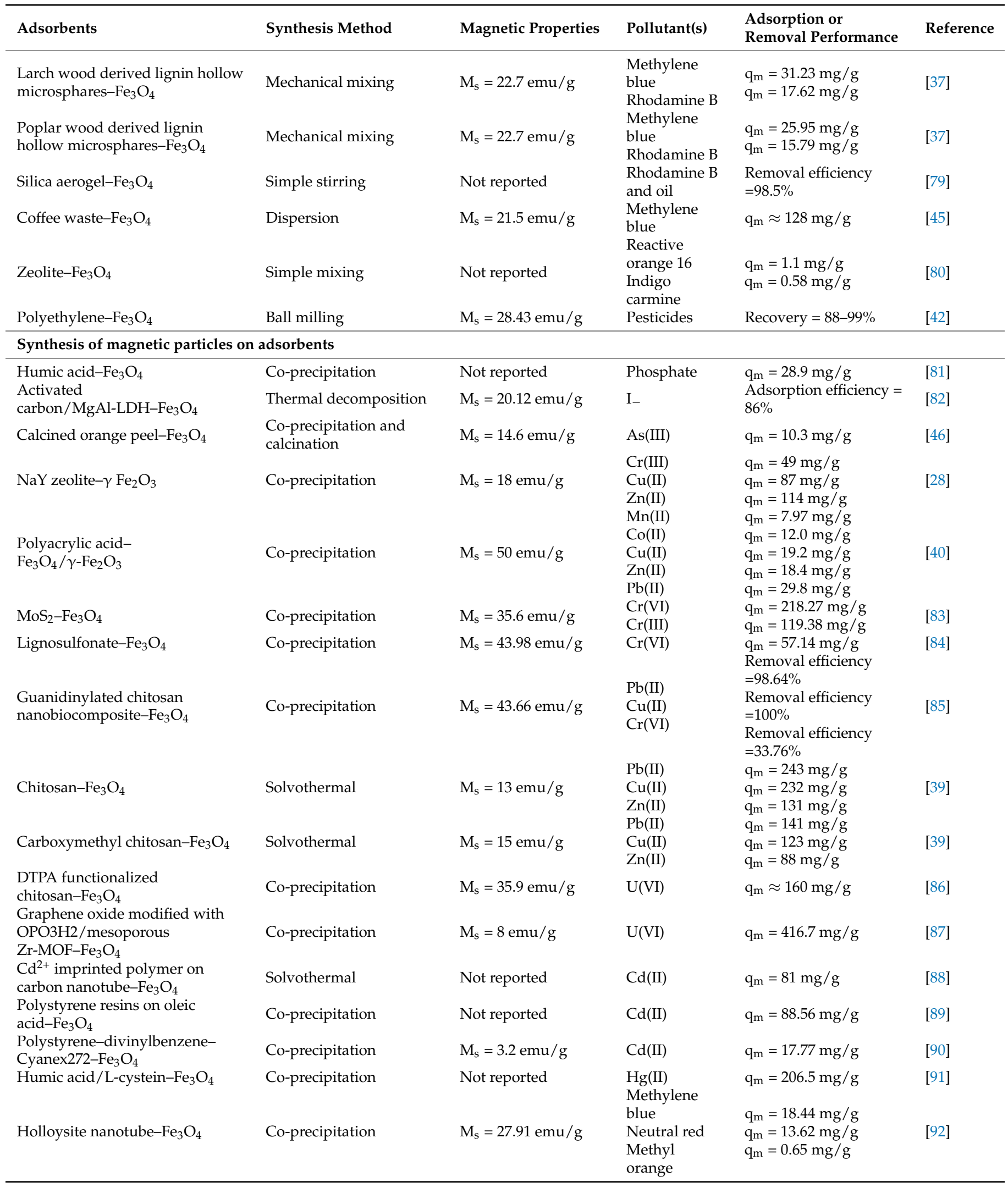


Table 1. Cont.

\begin{tabular}{|c|c|c|c|c|c|}
\hline Adsorbents & Synthesis Method & Magnetic Properties & Pollutant(s) & $\begin{array}{l}\text { Adsorption or } \\
\text { Removal Performance }\end{array}$ & Reference \\
\hline $\begin{array}{l}\text { Ce-MOF modified activated } \\
\text { carbon- } \mathrm{Fe}_{3} \mathrm{O}_{4}\end{array}$ & Co-precipitation & $\mathrm{M}_{\mathrm{s}}=21.39 \mathrm{emu} / \mathrm{g}$ & $\begin{array}{l}\text { Methylene } \\
\text { blue } \\
\text { Indigo } \\
\text { carmine }\end{array}$ & $\begin{array}{l}\text { Removal efficiency } \\
=98-99 \% \\
\text { Removal efficiency } \\
=98-99 \%\end{array}$ & [93] \\
\hline $\begin{array}{l}\mathrm{N} \text {-vinylpyrrolidon/chitosan } \\
\text { nanocomposite hydrogel- } \mathrm{Fe}_{3} \mathrm{O}_{4}\end{array}$ & Co-precipitation & $\mathrm{M}_{\mathrm{s}}=12 \mathrm{emu} / \mathrm{g}$ & $\begin{array}{l}\text { Methyl } \\
\text { orange }\end{array}$ & $\mathrm{q}_{\mathrm{m}} \approx 750 \mathrm{mg} / \mathrm{g}$ & [94] \\
\hline $\begin{array}{l}\beta \text {-cyclodextrin grafted carbon } \\
\text { nanotube- }-\mathrm{Fe}_{3} \mathrm{O}_{4}\end{array}$ & Co-precipitation & $\mathrm{M}_{\mathrm{s}}=7.15 \mathrm{emu} / \mathrm{g}$ & $\begin{array}{l}\text { Methylene } \\
\text { blue }\end{array}$ & $\mathrm{q}_{\mathrm{m}}=196.5 \mathrm{mg} / \mathrm{g}$ & [95] \\
\hline $\begin{array}{l}\text { Activated carbon- } \\
\mathrm{Fe}_{3} \mathrm{O}_{4} / \gamma-\mathrm{Fe}_{2} \mathrm{O}_{3}\end{array}$ & Solvothermal & $\mathrm{M}_{\mathrm{s}}>30 \mathrm{emu} / \mathrm{g}$ & $\begin{array}{l}\text { Methylene } \\
\text { blue }\end{array}$ & $\mathrm{q}_{\mathrm{m}}=196.5 \mathrm{mg} / \mathrm{g}$ & [96] \\
\hline $\begin{array}{l}\text { Mineral derived silica- } \mathrm{Fe}_{2} \mathrm{O}_{3} \text { and } \\
\text { plant derived silica- } \mathrm{Fe}_{2} \mathrm{O}_{3}\end{array}$ & $\begin{array}{l}\text { Precipitation, } \\
\text { impregnation, and } \\
\text { calcination }\end{array}$ & $\mathrm{M}_{\mathrm{s}} \approx 0.5-1.3 \mathrm{emu} / \mathrm{g}$ & $\begin{array}{l}\text { Methylene } \\
\text { blue }\end{array}$ & $\mathrm{q}_{\mathrm{m}}=7.0-27.3 \mathrm{mg} / \mathrm{g}$ & [97] \\
\hline Activated sericite clay- $-\mathrm{Fe}_{3} \mathrm{O}_{4}$ & Co-precipitation & $\begin{array}{l}\mathrm{M}_{\mathrm{s}}=2.17-8.12 \\
\mathrm{emu} / \mathrm{g}\end{array}$ & $\begin{array}{l}\text { Methylene } \\
\text { blue } \\
\text { Crystal violet }\end{array}$ & $\begin{array}{l}\text { Removal efficiency } \\
=99 \% \\
\text { Removal efficiency } \\
=99 \%\end{array}$ & [98] \\
\hline $\begin{array}{l}\text { Poly(itaconic } \\
\text { acid) } / \mathrm{Fe}_{3} \mathrm{O}_{4} \text {-sepiolite }\end{array}$ & Co-precipitation & $\mathrm{M}_{\mathrm{s}}=21.78 \mathrm{emu} / \mathrm{g}$ & $\begin{array}{l}\text { Methylene } \\
\text { blue } \\
\text { Methyl violet }\end{array}$ & $\begin{array}{l}\mathrm{q}_{\mathrm{m}}=196.08 \mathrm{mg} / \mathrm{g} \\
\mathrm{q}_{\mathrm{m}}=175.44 \mathrm{mg} / \mathrm{g}\end{array}$ & [99] \\
\hline Bentonite/APTMA- $\mathrm{Fe}_{3} \mathrm{O}_{4}$ & Co-precipitation & $\mathrm{M}_{\mathrm{s}}=0.7 \mathrm{emu} / \mathrm{g}$ & $\begin{array}{l}\text { Crystal violet } \\
\text { Congo red }\end{array}$ & $\begin{array}{l}\mathrm{q}_{\mathrm{m}}=2286 \mathrm{mg} / \mathrm{g} \\
\mathrm{q}_{\mathrm{m}}=1210 \mathrm{mg} / \mathrm{g}\end{array}$ & {$[100]$} \\
\hline $\mathrm{MoS}_{2} @$ bentonite-- $\mathrm{Fe}_{3} \mathrm{O}_{4}$ & Co-precipitation & $\mathrm{M}_{\mathrm{s}}=11.448 \mathrm{emu} / \mathrm{g}$ & Crystal violet & $\mathrm{q}_{\mathrm{m}}=384.61 \mathrm{mg} / \mathrm{g}$ & {$[101]$} \\
\hline $\begin{array}{l}\text { Activated carbon- } \\
\gamma \mathrm{Fe}_{2} \mathrm{O}_{3} / \mathrm{Fe}_{3} \mathrm{O}_{4} / \alpha-\mathrm{FeOOH}\end{array}$ & Co-precipitation & $\mathrm{M}_{\mathrm{s}}=38.5 \mathrm{emu} / \mathrm{g}$ & $\begin{array}{l}\text { Malachite } \\
\text { green }\end{array}$ & $\mathrm{q}_{\mathrm{m}}=486 \mathrm{mg} / \mathrm{g}$ & [102] \\
\hline Lignosulfonate- $-\mathrm{Fe}_{3} \mathrm{O}_{4}$ & Co-precipitation & $\mathrm{M}_{\mathrm{s}}=43.98 \mathrm{emu} / \mathrm{g}$ & Rhodamine B & $\mathrm{q}_{\mathrm{m}}=22.47 \mathrm{mg} / \mathrm{g}$ & [84] \\
\hline Reduced graphene oxide- $\mathrm{Fe}_{3} \mathrm{O}_{4}$ & Co-precipitation & $\mathrm{M}_{\mathrm{s}}=51.76 \mathrm{emu} / \mathrm{g}$ & Rhodamine B & $\mathrm{q}_{\mathrm{m}}=432.91 \mathrm{mg} / \mathrm{g}$ & [103] \\
\hline Mesoporous carbon- $\mathrm{Fe}_{3} \mathrm{O}_{4}$ & Solvothermal & $\mathrm{M}_{\mathrm{s}}=28.89 \mathrm{emu} / \mathrm{g}$ & Ciprofloxacin & $\mathrm{q}_{\mathrm{m}}=98.28 \mathrm{mg} / \mathrm{g}$ & {$[104]$} \\
\hline Polyacrylonitrile- $\mathrm{Fe}_{3} \mathrm{O}_{4}$ & Solvothermal & Not reported & Tetracycline & $\mathrm{q}_{\mathrm{m}}=257.07 \mathrm{mg} / \mathrm{g}$ & {$[105]$} \\
\hline Polypyrrole-chitosan- $\mathrm{Fe}_{3} \mathrm{O}_{4}$ & Co-precipitation & $\mathrm{M}_{\mathrm{s}}=22.30 \mathrm{emu} / \mathrm{g}$ & Carbamazepine & $\mathrm{q}_{\mathrm{m}}=121.95 \mathrm{mg} / \mathrm{g}$ & {$[106]$} \\
\hline $\begin{array}{l}\text { Graphene oxide/cyclodextrin } \\
\text { composite- }-\mathrm{Fe}_{3} \mathrm{O}_{4}\end{array}$ & Solvothermal & $\mathrm{M}_{\mathrm{s}}=43.96 \mathrm{emu} / \mathrm{g}$ & $\begin{array}{l}\text { Brivaracetam } \\
\text { Eslicarbazepine } \\
\text { acetate } \\
\text { Carbamazepine }\end{array}$ & $\begin{array}{l}\mathrm{q}_{\mathrm{m}}=36.38 \mathrm{mg} / \mathrm{g} \\
\mathrm{q}_{\mathrm{m}}=106.86 \mathrm{mg} / \mathrm{g} \\
\mathrm{q}_{\mathrm{m}}=54.49 \mathrm{mg} / \mathrm{g}\end{array}$ & [107] \\
\hline $\begin{array}{l}\text { Carbon nanofiber } \\
\text { aerogels-Fe } / \mathrm{Fe}_{3} \mathrm{O}_{4} \text { core-shell }\end{array}$ & Co-precipitation & $\mathrm{M}_{\mathrm{s}}=102 \mathrm{emu} / \mathrm{g}$ & $\begin{array}{l}\text { Oil and } \\
\text { organic } \\
\text { solvents }\end{array}$ & $\begin{array}{l}\mathrm{q}_{\mathrm{m}}=37,000-87,000 \\
\mathrm{mg} / \mathrm{g}\end{array}$ & [108] \\
\hline \multicolumn{6}{|c|}{ Synthesis of adsorbents on magnetic particles } \\
\hline $\mathrm{La}(\mathrm{OH})_{3}-\mathrm{Fe}_{3} \mathrm{O}_{4}$ & Precipitation & $\mathrm{M}_{\mathrm{S}}=15-20 \mathrm{emu} / \mathrm{g}$ & Phosphate & $\mathrm{q}_{\mathrm{m}}=11.77 \mathrm{mg} / \mathrm{g}$ & [109] \\
\hline C18-functionalized silica- $\mathrm{Fe}_{3} \mathrm{O}_{4}$ & Sol-gel & $\mathrm{M}_{\mathrm{s}}=39.19 \mathrm{emu} / \mathrm{g}$ & Phosphate & $\mathrm{q}_{\mathrm{m}}=0.3143 \mathrm{mg} / \mathrm{g}$ & {$[12]$} \\
\hline P zeolite- $-\mathrm{Fe}_{3} \mathrm{O}_{4}$ & Hydrothermal & $\mathrm{M}_{\mathrm{s}}=2.8855 \mathrm{emu} / \mathrm{g}$ & $\mathrm{K}(\mathrm{I})$ & $\mathrm{q}_{\mathrm{m}}=215.1 \mathrm{mg} / \mathrm{g}$ & [110] \\
\hline Mordenite zeolite- $\mathrm{Fe}_{3} \mathrm{O}_{4}$ & Hydrothermal & $\begin{array}{l}\text { Magnetic collection } \\
\text { rate }=95 \%\end{array}$ & $\mathrm{Cs}(\mathrm{I})$ & $\begin{array}{l}\text { Removal efficiency } \\
>95 \%\end{array}$ & [111] \\
\hline $\begin{array}{l}\text { Amino functionalized } \\
\text { silica- }-\mathrm{Fe}_{3} \mathrm{O}_{4}\end{array}$ & Sol-gel & $\mathrm{M}_{\mathrm{s}}=60.6 \mathrm{emu} / \mathrm{g}$ & $\begin{array}{l}\mathrm{Cr}(\mathrm{III}) \\
\mathrm{Cr}(\mathrm{VI})\end{array}$ & $\begin{array}{l}\mathrm{q}_{\mathrm{m}}=8.22 \mathrm{mg} / \mathrm{g} \\
\mathrm{q}_{\mathrm{m}}=11.4 \mathrm{mg} / \mathrm{g}\end{array}$ & [112] \\
\hline $\begin{array}{l}\text { Poly(m-phenylenediamine)- } \\
\mathrm{Fe}_{3} \mathrm{O}_{4}\end{array}$ & $\begin{array}{l}\text { Oxidation- } \\
\text { polymerization }\end{array}$ & $\begin{array}{l}\mathrm{M}_{\mathrm{s}}=73.78-127.33 \\
\mathrm{emu} / \mathrm{g}\end{array}$ & $\mathrm{Cr}(\mathrm{VI})$ & $\begin{array}{l}\mathrm{q}_{\mathrm{m}}=125.62-246.09 \\
\mathrm{mg} / \mathrm{g}\end{array}$ & [113] \\
\hline $\begin{array}{l}\text { SDS-PAN functionalized } \\
\text { alumina- } \mathrm{Fe}_{3} \mathrm{O}_{4}\end{array}$ & Direct precipitation & Not reported & $\mathrm{Co}(\mathrm{II})$ & $\begin{array}{l}\text { Recovery } \\
=95.6-98.8 \%\end{array}$ & [114] \\
\hline ZSM-5 zeolite- $\mathrm{Fe}_{3} \mathrm{O}_{4}$ & Hydrothermal & $\mathrm{M}_{\mathrm{s}}=0.8743 \mathrm{emu} / \mathrm{g}$ & $\mathrm{Pb}(\mathrm{II})$ & $\mathrm{q}_{\mathrm{m}}=176.76 \mathrm{mg} / \mathrm{g}$ & {$[115]$} \\
\hline Graphene oxide-LDH- $\mathrm{Fe}_{3} \mathrm{O}_{4}$ & $\begin{array}{l}\text { Milling and } \\
\text { hydrothermal }\end{array}$ & $\mathrm{M}_{\mathrm{s}}=3.5 \mathrm{emu} / \mathrm{g}$ & $\mathrm{Pb}(\mathrm{II})$ & $\mathrm{q}_{\mathrm{m}}=39.7 \mathrm{mg} / \mathrm{g}$ & [116] \\
\hline $\begin{array}{l}\text { Amino functionalized } \\
\text { silica- }-\mathrm{Fe}_{3} \mathrm{O}_{4}\end{array}$ & Sol-gel & $\mathrm{M}_{\mathrm{s}}=29.3 \mathrm{emu} / \mathrm{g}$ & $\mathrm{Pb}(\mathrm{II})$ & $\mathrm{q}_{\mathrm{m}}=238 \mathrm{mg} / \mathrm{g}$ & [117] \\
\hline $\mathrm{NaA}$ zeolite- $-\mathrm{Fe}_{3} \mathrm{O}_{4}$ & Hydrothermal & $\chi_{\rho}=225-515 \mathrm{~m}^{3} / \mathrm{kg}$ & $\begin{array}{l}\mathrm{Cu}(\mathrm{II}) \\
\mathrm{Pb}(\mathrm{II})\end{array}$ & $\begin{array}{l}\mathrm{q}_{\mathrm{m}}=146 \mathrm{mg} / \mathrm{g} \\
\mathrm{q}_{\mathrm{m}}=477 \mathrm{mg} / \mathrm{g}\end{array}$ & [118] \\
\hline $\mathrm{ZIF}-8-\mathrm{Fe}_{3} \mathrm{O}_{4}$ & Stirring & $\mathrm{M}_{\mathrm{s}}=37.26 \mathrm{emu} / \mathrm{g}$ & $\begin{array}{l}\mathrm{Pb}(\mathrm{II}) \\
\mathrm{Cu}(\mathrm{II})\end{array}$ & $\begin{array}{l}\mathrm{q}_{\mathrm{m}}=719.42 \mathrm{mg} / \mathrm{g} \\
\mathrm{q}_{\mathrm{m}}=301.33 \mathrm{mg} / \mathrm{g}\end{array}$ & [119] \\
\hline $\begin{array}{l}\text { Carboxymethylated lignin } \\
\text { functionalized silica- } \mathrm{Fe}_{3} \mathrm{O}_{4}\end{array}$ & Sol-gel & Not reported & $\begin{array}{l}\mathrm{Pb}(\mathrm{II}) \\
\mathrm{Cu}(\mathrm{II})\end{array}$ & $\begin{array}{l}\mathrm{q}_{\mathrm{m}}=150.33 \mathrm{mg} / \mathrm{g} \\
\mathrm{q}_{\mathrm{m}}=70.69 \mathrm{mg} / \mathrm{g}\end{array}$ & [120] \\
\hline
\end{tabular}


Table 1. Cont.

\begin{tabular}{|c|c|c|c|c|c|}
\hline Adsorbents & Synthesis Method & Magnetic Properties & Pollutant(s) & $\begin{array}{l}\text { Adsorption or } \\
\text { Removal Performance }\end{array}$ & Reference \\
\hline $\mathrm{MnO}_{2}-\mathrm{Fe}_{3} \mathrm{O}_{4}$ & Hydrothermal & $\mathrm{M}_{\mathrm{s}}=14.19 \mathrm{emu} / \mathrm{g}$ & $\begin{array}{l}\mathrm{Cu}(\mathrm{II}) \\
\mathrm{Cd}(\mathrm{II}) \\
\mathrm{Zn}(\mathrm{II}) \\
\mathrm{Pb}(\mathrm{II})\end{array}$ & $\begin{array}{l}\mathrm{q}_{\mathrm{m}}=498.575 \mathrm{mg} / \mathrm{g} \\
\mathrm{q}_{\mathrm{m}}=439 \mathrm{mg} / \mathrm{g} \\
\mathrm{q}_{\mathrm{m}}=416.5 \mathrm{mg} / \mathrm{g} \\
\mathrm{q}_{\mathrm{m}}=490.5 \mathrm{mg} / \mathrm{g}\end{array}$ & [27] \\
\hline $\begin{array}{l}\text { Siloxydithiocarbamate } \\
\text { functionalized silica- } \mathrm{Fe}_{3} \mathrm{O}_{4}\end{array}$ & Sol-gel & $\mathrm{M}_{\mathrm{s}} \approx 70 \mathrm{emu} / \mathrm{g}$ & $\mathrm{Hg}(\mathrm{II})$ & $\begin{array}{l}\text { Removal efficiency > } \\
99.8 \%\end{array}$ & [121] \\
\hline $\begin{array}{l}\text { DPTH-functionalized } \\
\text { silica- } \mathrm{Fe}_{3} \mathrm{O}_{4} \\
\text { Sulfur functionalized amide }\end{array}$ & Sol-gel & Not reported & $\mathrm{Hg}(\mathrm{II})$ & $\mathrm{q}_{\mathrm{m}}=8.39 \mathrm{mg} / \mathrm{g}$ & [122] \\
\hline $\begin{array}{l}\text { Sulfur functionalized amide } \\
\text { linked organic } \\
\text { polymer-MNP-NH} 2\end{array}$ & Sol-gel & $\mathrm{M}_{\mathrm{s}}=15 \mathrm{emu} / \mathrm{g}$ & $\operatorname{Hg}(\mathrm{II})$ & $\mathrm{q}_{\mathrm{m}}=512 \mathrm{mg} / \mathrm{g}$ & [123] \\
\hline $\begin{array}{l}\text { Microbial extracellular polymeric } \\
\text { substances coated } \mathrm{Fe}_{3} \mathrm{O}_{4}\end{array}$ & $\begin{array}{l}\text { Oxidative } \\
\text { copolymerization }\end{array}$ & $\mathrm{M}_{\mathrm{s}}=79.01 \mathrm{emu} / \mathrm{g}$ & $\operatorname{Ag}(\mathrm{I})$ & $\mathrm{q}_{\mathrm{m}}=48 \mathrm{mg} / \mathrm{g}$ & [124] \\
\hline $\begin{array}{l}\text { Hydrothermal carbon modified } \\
\text { with } \mathrm{NaOH}-\mathrm{Fe}_{3} \mathrm{O}_{4}\end{array}$ & Hydrothermal & Not reported & $\mathrm{U}(\mathrm{VI})$ & $\mathrm{q}_{\mathrm{m}}=761.20 \mathrm{mg} / \mathrm{g}$ & [125] \\
\hline $\begin{array}{l}\text { Amidoxime functionalized } \\
\text { flower-like } \mathrm{TiO}_{2} \\
\text { microspheres- } \mathrm{Fe}_{3} \mathrm{O}_{4}\end{array}$ & Sol-gel & $\mathrm{M}_{\mathrm{s}}=15.19 \mathrm{emu} / \mathrm{g}$ & $\mathrm{U}(\mathrm{VI})$ & $\mathrm{q}_{\mathrm{m}}=313.6 \mathrm{mg} / \mathrm{g}$ & [126] \\
\hline $\begin{array}{l}\text { Amino-methylene-phosphonic- } \\
\text { functionalized } \\
\text { silica- } \mathrm{Fe}_{3} \mathrm{O}_{4}\end{array}$ & Sol-gel & Not reported & $\mathrm{Sb}(\mathrm{III})$ & $\mathrm{q}_{\mathrm{m}} \approx 130 \mathrm{mg} / \mathrm{g}$ & [127] \\
\hline $\begin{array}{l}\text { Thiol functionalized silica- } \mathrm{Fe}_{3} \mathrm{O}_{4} \\
\mathrm{C} 18-\mathrm{Silica}-\mathrm{Fe}_{3} \mathrm{O}_{4}\end{array}$ & $\begin{array}{l}\text { Sol-gel } \\
\text { Sol-gel }\end{array}$ & $\begin{array}{l}\text { Not reported } \\
\mathrm{M}_{\mathrm{s}}=41.31 \mathrm{emu} / \mathrm{g}\end{array}$ & $\begin{array}{l}{[\mathrm{AuCl} 4]_{-}} \\
\text {Sudan dyes }\end{array}$ & $\begin{array}{l}\mathrm{q}_{\mathrm{m}}=115 \mathrm{mg} / \mathrm{g} \\
\text { Recovery }=91-104 \%\end{array}$ & $\begin{array}{l}{[128]} \\
{[129]}\end{array}$ \\
\hline $\mathrm{TiO}_{2} / \mathrm{HKUST}-1-\mathrm{Fe}_{3} \mathrm{O}_{4}$ & Spray-assisted synthesis & $\mathrm{M}_{\mathrm{s}}=1.62 \mathrm{emu} / \mathrm{g}$ & $\begin{array}{l}\text { Methylene } \\
\text { blue }\end{array}$ & $\mathrm{q}_{\mathrm{m}}>700 \mathrm{mg} / \mathrm{g}$ & {$[130]$} \\
\hline $\mathrm{ZIF}-8-\mathrm{Fe}_{3} \mathrm{O}_{4}$ & Mixing and heating & $\mathrm{M}_{\mathrm{s}}=14.38 \mathrm{emu} / \mathrm{g}$ & $\begin{array}{l}\text { Methylene } \\
\text { blue }\end{array}$ & $\mathrm{q}_{\mathrm{m}}=20.2 \mathrm{mg} / \mathrm{g}$ & [131] \\
\hline $\begin{array}{l}\text { Poly(propylene } \\
\text { imine)-functionalized } \\
\mathrm{UiO}-66-\mathrm{Fe}_{3} \mathrm{O}_{4}\end{array}$ & Solvothermal & $\mathrm{M}_{\mathrm{s}}=10.5 \mathrm{emu} / \mathrm{g}$ & $\begin{array}{l}\text { Acid blue } 92 \\
\text { Direct red } 31\end{array}$ & $\begin{array}{l}\mathrm{q}_{\mathrm{m}}=122.5 \mathrm{mg} / \mathrm{g} \\
\mathrm{q}_{\mathrm{m}}=173.7 \mathrm{mg} / \mathrm{g}\end{array}$ & [132] \\
\hline $\begin{array}{l}\text { Chitosan-based adsorbent } \\
\text { modified with } \mathrm{AO}-\mathrm{Fe}_{3} \mathrm{O}_{4}\end{array}$ & Sol-gel & $\mathrm{M}_{\mathrm{s}}=12.03 \mathrm{emu} / \mathrm{g}$ & $\begin{array}{l}\text { Orange II } \\
\text { Acid red } 88 \\
\text { Red amaranth }\end{array}$ & $\begin{array}{l}\mathrm{q}_{\mathrm{m}}=955.0 \mathrm{mg} / \mathrm{g} \\
\mathrm{q}_{\mathrm{m}}=1075.8 \mathrm{mg} / \mathrm{g} \\
\mathrm{q}_{\mathrm{m}}=567.5 \mathrm{mg} / \mathrm{g}\end{array}$ & [133] \\
\hline $\begin{array}{l}\text { Polydopamine-coated } \mathrm{Fe}_{3} \mathrm{O}_{4} \\
\text { modified with deep eutectic } \\
\text { solvents }\end{array}$ & Self-polymerization & $\mathrm{M}_{\mathrm{s}}=65.71 \mathrm{emu} / \mathrm{g}$ & $\begin{array}{l}\text { Malachite } \\
\text { green } \\
\text { Sunset yellow } \\
\text { FCF }\end{array}$ & $\begin{array}{l}\mathrm{q}_{\mathrm{m}}=277.78 \mathrm{mg} / \mathrm{g} \\
\mathrm{q}_{\mathrm{m}}=129.27 \mathrm{mg} / \mathrm{g}\end{array}$ & [134] \\
\hline $\begin{array}{l}\text { Sulfamic acid-functionalized } \\
\text { polyamidoamine- } \mathrm{Fe}_{3} \mathrm{O}_{4}\end{array}$ & Ultrasonication & $\mathrm{M}_{\mathrm{s}}=25 \mathrm{emu} / \mathrm{g}$ & $\begin{array}{l}\text { Malachite } \\
\text { green }\end{array}$ & $\mathrm{q}_{\mathrm{m}}=1250 \mathrm{mg} / \mathrm{g}$ & [135] \\
\hline $\begin{array}{l}\text { Sulfonic acid functionalized } \\
\text { covalent organic polymer- } \mathrm{Fe}_{3} \mathrm{O}_{4}\end{array}$ & Sol-gel & $\mathrm{M}_{\mathrm{s}}=20.2 \mathrm{emu} / \mathrm{g}$ & $\begin{array}{l}\text { Malachite } \\
\text { green }\end{array}$ & $\mathrm{q}_{\mathrm{m}}=333.4 \mathrm{mg} / \mathrm{g}$ & [136] \\
\hline $\begin{array}{l}\text { Cationic surfactant functionalized } \\
\text { silica- } \mathrm{Fe}_{3} \mathrm{O}_{4}\end{array}$ & Sol-gel & Not reported & $\begin{array}{l}\text { Metal ion-8- } \\
\text { hydroxyqui- } \\
\text { noline } \\
\text { complexes }\end{array}$ & Recovery $=93-113 \%$ & [137] \\
\hline $\begin{array}{l}\mathrm{C} 18 \text {-functionalized } \mathrm{Fe}_{3} \mathrm{O}_{4} \text { caged } \\
\text { in } \mathrm{Ba}^{2+} \text {-alginate }\end{array}$ & Solvothermal & $\mathrm{M}_{\mathrm{s}}=49.31 \mathrm{emu} / \mathrm{g}$ & $\begin{array}{l}\text { PAHs } \\
\text { Phthalate } \\
\text { esters }\end{array}$ & Recovery $=72-108 \%$ & [138] \\
\hline $\begin{array}{l}\mathrm{C} 18 \text {-modified interior pore wall } \\
\text { mesoporous silica- } \mathrm{Fe}_{3} \mathrm{O}_{4}\end{array}$ & Sol-gel & $\mathrm{M}_{\mathrm{s}}=40.8 \mathrm{emu} / \mathrm{g}$ & Phthalates & Not reported & [139] \\
\hline Graphene oxide- $\mathrm{LDH}-\mathrm{Fe}_{3} \mathrm{O}_{4}$ & $\begin{array}{l}\text { Milling and } \\
\text { hydrothermal }\end{array}$ & $\mathrm{M}_{\mathrm{s}}=3.5 \mathrm{emu} / \mathrm{g}$ & $\begin{array}{l}\text { 2,4-dichloro- } \\
\text { phenoxyacetic } \\
\text { acid }\end{array}$ & $\mathrm{q}_{\mathrm{m}}=173 \mathrm{mg} / \mathrm{g}$ & [116] \\
\hline $\begin{array}{l}\text { Agarose coated silica modified } \\
\text { with SDS- } \mathrm{Fe}_{3} \mathrm{O}_{4}\end{array}$ & Sol-gel & $\mathrm{M}_{\mathrm{s}}=21.57 \mathrm{emu} / \mathrm{g}$ & $\begin{array}{l}\text { Phenazopyri- } \\
\text { dine monohy- } \\
\text { drochloride }\end{array}$ & $\mathrm{q}_{\mathrm{m}}=41 \mathrm{mg} / \mathrm{g}$ & [140] \\
\hline $\begin{array}{l}\text { Covalent organic } \\
\text { framework- }-\mathrm{Fe}_{3} \mathrm{O}_{4}\end{array}$ & Sol-gel & $\mathrm{M}_{\mathrm{s}}=15.8 \mathrm{emu} / \mathrm{g}$ & $\begin{array}{l}\text { Diclofenac } \\
\text { sodium }\end{array}$ & $\mathrm{q}_{\mathrm{m}}=565 \mathrm{mg} / \mathrm{g}$ & [141] \\
\hline
\end{tabular}

$\mathrm{M}_{\mathrm{s}}$ : saturation magnetization; $\chi_{\rho}=$ magnetic susceptibility; $\mathrm{q}_{\mathrm{m}}$ : maximum adsorption capacity; AO: acryloyloxyethyl dimethylbenzyl ammonium chloride; APTMA: 3-acrylamidopropyltrimethylammonium chloride; CSSNa: sodium dithiocarbamate; DTPA: diethylenetriamine pentaacetic acid; HKUST-1: Cu $\mathrm{Cu}_{3}(1,3,5-$ benzenetricarboxylate) ${ }_{2}$; LDH: layered double hydroxide; $\mathrm{MNP}-\mathrm{NH}_{2}: \mathrm{Fe}_{3} \mathrm{O}_{4} @ \mathrm{SiO}_{2}-\mathrm{NH}_{2} ; \mathrm{MOF}$ : metal organic framework; PAHs: polyaromatic hydrocarbons; PAN: 1-(2-pyridylazo)-2-naphthol; PGMA: polyglycidyl methacrylate; SDS: sodium dodecylsulfate; ZIF-8: Zn(2-methylimidazole) $)_{2}$. 


\subsection{Adsorption Using Magnetic Material Adsorbents}

Various magnetic materials, especially iron-based materials, such as nano zerovalent iron (nZVI), maghemite $\left(\gamma-\mathrm{Fe}_{2} \mathrm{O}_{3}\right)$, and magnetite $\left(\mathrm{Fe}_{3} \mathrm{O}_{4}\right)$, have received extensive attention for use as magnetic adsorbents. The effective control of particle sizes, crystal structures, and shapes are key issues in the synthesis of magnetic material adsorbents.

\subsection{1. nZVI}

A wide range of experimental studies have been conducted on magnetic nZVI, owing to its strong reducing properties. Through surface corrosion and precipitation, nZVI can efficiently reduce heavy metal ions, such as hexavalent chromium $(\mathrm{Cr}(\mathrm{VI}))$ and some pollutants with low degradability. Compared to other conventional decontamination methods, such as precipitation, ion exchange, and metal complexes, adsorption by nZVI has many advantages. For example, ZVI-based composites could be more cost-effective for in situ environmental applications, and the oxides or hydroxides of iron are natural minerals, which makes the composites eco-friendly.

Chemical reaction, due to its simplicity, is the most frequently used method to synthesize nZVI. Among chemical reactions, the use of sodium borohydride $\left(\mathrm{NaBH}_{4}\right)$ to reduce the Fe-containing precursor at elevated temperatures has been very popular. Another chemical method to obtain $\mathrm{nZVI}$ is the reduction of ferrous oxides in an $\mathrm{H}_{2}$ atmosphere, at around $500{ }^{\circ} \mathrm{C}$. In addition, some physical methods, such as ball milling and ultrasound assistance, wherein the particle size can be decreased from micrometer to nanometer without using any toxic reagents, can be used to obtain nZVI in a much easier and safer way.

Bare nZVI particles have a large surface area, which is beneficial for increasing the removal capacity. The capacity reached $40 \mathrm{mg} / \mathrm{g}$ in a Cd(II) solution, though the capacity varied with different initial concentrations or different initial $\mathrm{pH}$ values [142]. However, surface oxidation is a serious problem that limits the further applications of nZVI; the powerful reducing property can act on non-target pollutants, decreasing the selectivity. In air, the formation of a passivation layer inhibits the reactivity of nZVI. Moreover, nZVI particles aggregate much more easily than other non-magnetic, iron-based materials, owing to the surface tension. Surface coating engineering and template confinement can help address these problems (Figure 2).

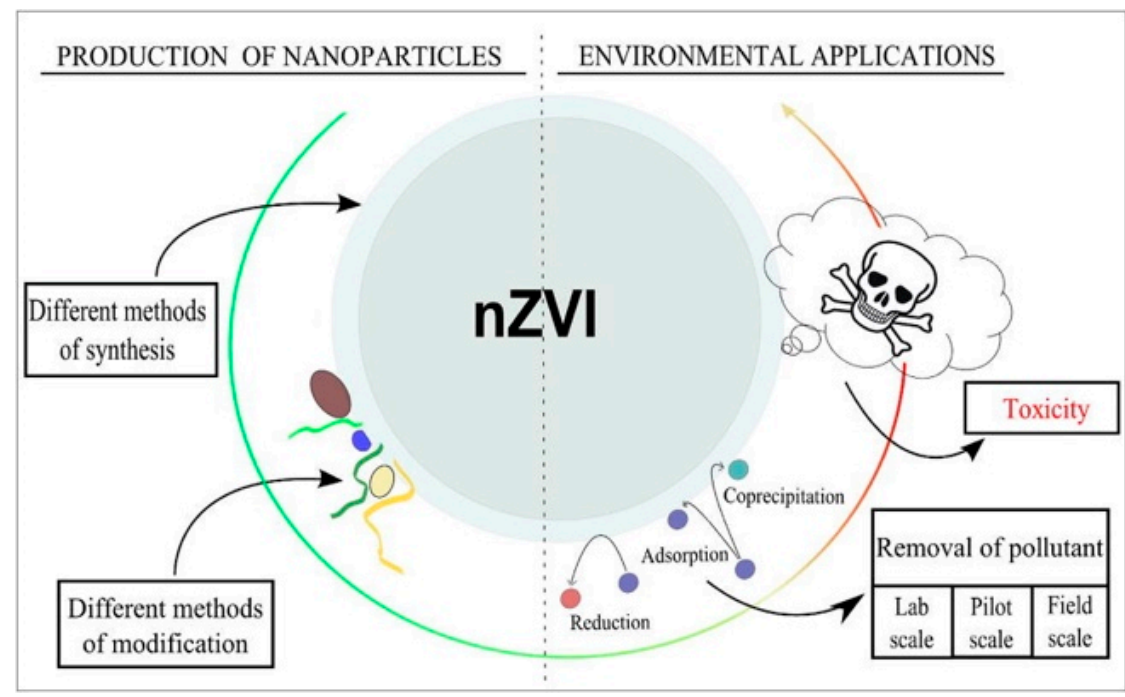

Figure 2. Brief depiction of the synthesis and environmental applications of nZVI (Reprinted from Chem. Eng. J., 287, Stefaniuk, M.; Oleszczuk, P.; Ok, Y.S. Review on nano zerovalent iron (nZVI): From synthesis to environmental applications, 618-632. Ref. [143], Copyright ( 2022 with permission from Elsevier). 


\subsection{2. $\gamma-\mathrm{Fe}_{2} \mathrm{O}_{3}$}

$\gamma-\mathrm{Fe}_{2} \mathrm{O}_{3}$ is mainly obtained by the oxidation of iron, magnetite, or organometallic iron, or the calcination of iron hydroxide. As $\gamma-\mathrm{Fe}_{2} \mathrm{O}_{3}$ is a stable iron oxide, its adsorption to heavy metals can often be attributed to physical interactions, such as electrostatic attraction or van der Waals forces. Physical bonding has poor stability in preventing the adsorbents from leaching nanoparticle cores or metal pollutants. Therefore, the construction and design of adsorbents that form more chemical bonds have been investigated. Ahmed et al. [63] studied a mixture of $\mathrm{Fe}_{3} \mathrm{O}_{4}$ and $\gamma-\mathrm{Fe}_{2} \mathrm{O}_{3}$ particles, to remove $\mathrm{Pb}$ (II), $\mathrm{Cr}(\mathrm{III})$, and $\mathrm{Cd}$ (II); the removal capacity reached $617.3,277.0$, and $223.7 \mathrm{mg} / \mathrm{g}$, respectively. For phosphate, this type of mixed adsorbent can also achieve a 95\% removal efficiency [18]. Another mixed iron oxide, $\alpha-\mathrm{Fe}_{2} \mathrm{O}_{3}$ and $\gamma-\mathrm{Fe}_{2} \mathrm{O}_{3}$, could uptake $46.5 \mathrm{mg} / \mathrm{g} \mathrm{As}(\mathrm{III})$, by forming inner-sphere surface complexes [61].

The magnetism and particle sizes of iron oxide nanoparticles are affected by the preparation methods. Hydrothermal methods can achieve smaller nanoparticles and other methods may have aggregation problems. Hence, the stabilizer and surfactant materials should be added in the synthesis process to ensure an even dispersion of the particles. Moreover, the nature of chemical or physical bonding should be further understood, by investigating the mechanisms between the adsorbents and pollutants.

\subsection{3. $\mathrm{Fe}_{3} \mathrm{O}_{4}$}

Magnetic $\mathrm{Fe}_{3} \mathrm{O}_{4}$ has been extensively studied because of its stability, natural abundance, low cost, and environmental friendliness.

Co-precipitation is the conventional method of synthesizing $\mathrm{Fe}_{3} \mathrm{O}_{4}$. First, $\mathrm{Fe}(\mathrm{II})$ and $\mathrm{Fe}(\mathrm{III})$ are mixed at a ratio of 1:2, and the resulting black powders are achieved once the solution $\mathrm{pH}$ becomes neutral [60]. Although this method is cheap and convenient, the final particle possesses sharp diffraction peaks in the X-ray diffraction (XRD) patterns, revealing that $\mathrm{Fe}_{3} \mathrm{O}_{4}$ is a type of bulk material. For $\mathrm{Fe}_{3} \mathrm{O}_{4}$ adsorbents, both physical adsorption and chemical reduction properties have been reported as removal mechanisms. Advanced $\mathrm{X}$-ray photoelectron spectroscopy (XPS) and XRD were used to analyze the lattice structure and elemental valence state, before and after adsorption. For $\mathrm{Cr}(\mathrm{VI})$ anions, a $\mathrm{Cr}(\mathrm{III})$ oxyhydroxide or hydroxide-phase passive layer was formed on the surface of magnetite, which preferentially reacted with magnetite (111) [144]. In addition, the large surface area and abundant functional groups provided many active sorption sites. Thus, highly dispersed nanoparticles play a key role in the exposure of these sorption sites. To obtain smaller-sized particles, Rajput et al. added tetraethyl ammonium hydroxide (TEAOH) to the $\mathrm{Fe}_{3} \mathrm{O}_{4}$ product, to prevent agglomeration (Figure 3) [65]. Yusoff et al. [145] found that smaller magnetite particles were easier to obtain when the $\mathrm{pH}$ of the co-precipitation solution was greater than 12 . After treatment with amino silane groups, the kinetic stability of this magnetic particle can be further developed [59]. Other approaches have also been reported for the preparation of magnetite, including the oxidation of Fe(II) by oxygen, or the reduction of $\mathrm{Fe}(\mathrm{III})$ by reducing bacteria $[15,64]$.

The influence of the solution $\mathrm{pH}$ on the production of magnetic material adsorbent has been further studied. Gnanaprakash et al. [146] investigated how the initial $\mathrm{pH}$ of the salt solution influences the synthesis of magnetite. Additionally, the results showed that $100 \%$ spinel iron oxide was formed when the salt solution was below 5 ; as the $\mathrm{pH}$ was increased from 5.7 to 6.7 , the percentage of goethite rose from $35 \%$ to $78 \%$. The final $\mathrm{pH}$ is known to control the nucleation and growth of magnetite nanoparticles and can affect the size and saturation magnetization. In a certain $\mathrm{pH}$ range, the protonation/deprotonation of $\mathrm{Fe}-\mathrm{OH}$ takes place, which can hinder the aggregation of magnetite particles, due to the combined steric and electrostatic stabilization [147,148]. Besides, the solution $\mathrm{pH}$ after adsorption treatment also plays a critical role in recycling performance. By adjusting the proton concentration, the surface charge of magnetite changes; thus, the pollutant can be desorbed by electrostatic forces [149]. 
Magnetite nanoparticles can also be directly synthesized by the thermal decomposition of $\mathrm{Fe}(\mathrm{III})$ acetylacetonate $\left(\mathrm{Fe}(\mathrm{acac})_{3}\right)$ in tris(ethylene glycol), wherein the resultant average crystallite size is approximately $10.7 \mathrm{~nm}$ [150]. However, the final magnetite product from ferrous oxalate dihydrate, after heat treatment, is still a bulk material, even at temperatures below $90{ }^{\circ} \mathrm{C}$ [151]. Thus, the size distribution and crystallinity are mostly dependent on the Fe-containing precursors. For example, organometallic iron compounds, such as $\mathrm{Fe}(\mathrm{III})$-acetylacetonate and Fe(III)-N-nitroso phenylhydroxylamine, are mixed in organic solvents, such as oleic acid and oleylamine. The stabilizer may inhibit the nucleation and growth process of iron oxide, so that it is well controlled in size and shape.

During the thermal decomposition, the radius of the nanoparticles can be controlled by tuning the reaction temperature and the mass ratios of the solvent reagents. Lassenberger et al. [152] further optimized monodisperse iron oxides using oleic acid as a surfactant, and the results showed that a fast heating rate accelerates the nucleation and growth of iron oxide particles. In contrast, a wide size distribution and larger particle size can also occur when the annealing duration is prolonged.

(a)

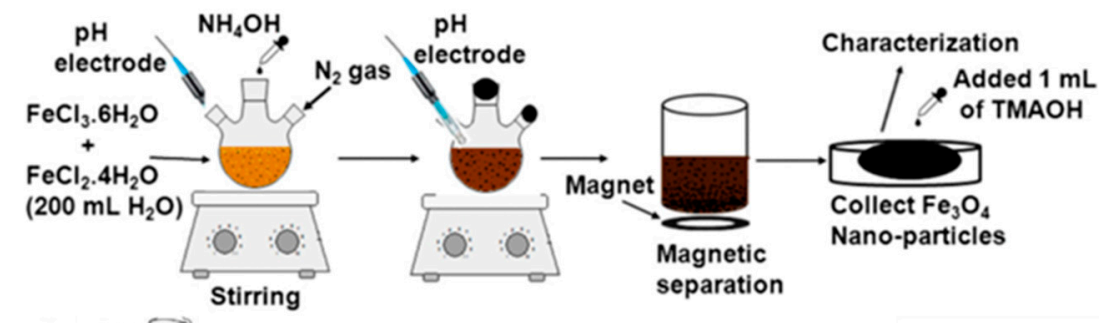

(b)

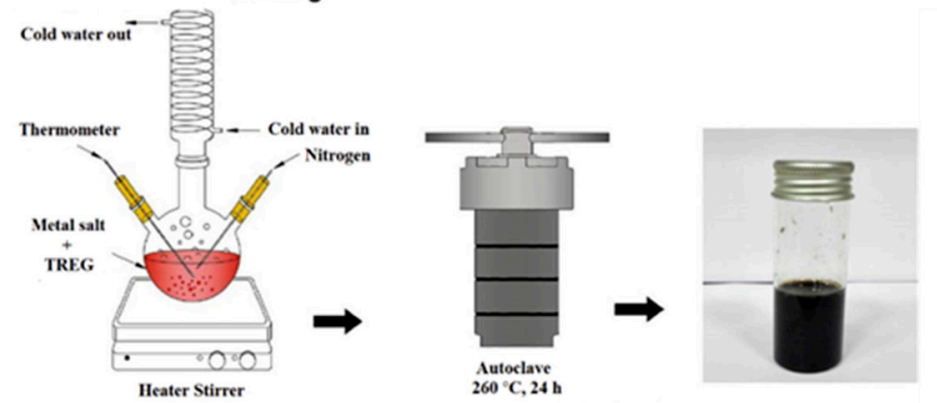

Figure 3. Preparation procedures of $\mathrm{Fe}_{3} \mathrm{O}_{4}$ by (a) coprecipitation and (b) solvothermal synthesis. (Reprinted from J. Colloid. Interface Sci. 468, Rajput, S.; Pittman Jr., C.U.; Mohan, D. Magnetic magnetite $\left(\mathrm{Fe}_{3} \mathrm{O}_{4}\right)$ nanoparticle synthesis and applications for lead $\left(\mathrm{Pb}^{2+}\right)$ and chromium $\left(\mathrm{Cr}^{6+}\right)$ removal from water, 334-346. Ref. [65], Copyright (C) 2022 and J. Alloys Compd. 816, Fotukian, S.M.; Barati, A.; Soleymani, M.; Alizadeh, A.M. Solvothermal synthesis of $\mathrm{CuFe}_{2} \mathrm{O}_{4}$ and $\mathrm{Fe}_{3} \mathrm{O}_{4}$ nanoparticles with high heating efficiency for magnetic hyperthermia application, 152548 Ref. [153], Copyright () 2022 with permission from Elsevier).

\subsection{Attaching Pre-Synthesized Magnetic Particles and Adsorbents}

Because the adsorption performance of magnetic materials is rather low, many researchers have sought to embed magnetic properties into well-known adsorbents. The attachment of pre-synthesized adsorbents and pre-synthesized magnetic materials is one such approach. Several methods, including attachment by organic adhesives, electrostatic interactions, self-assembly, crosslinking reactions, and mechanical bonding, can be used in this approach. Pre-synthesized materials include commercial products, apart from the ones developed in laboratories. The attachment methods are summarized in Figure 4. 


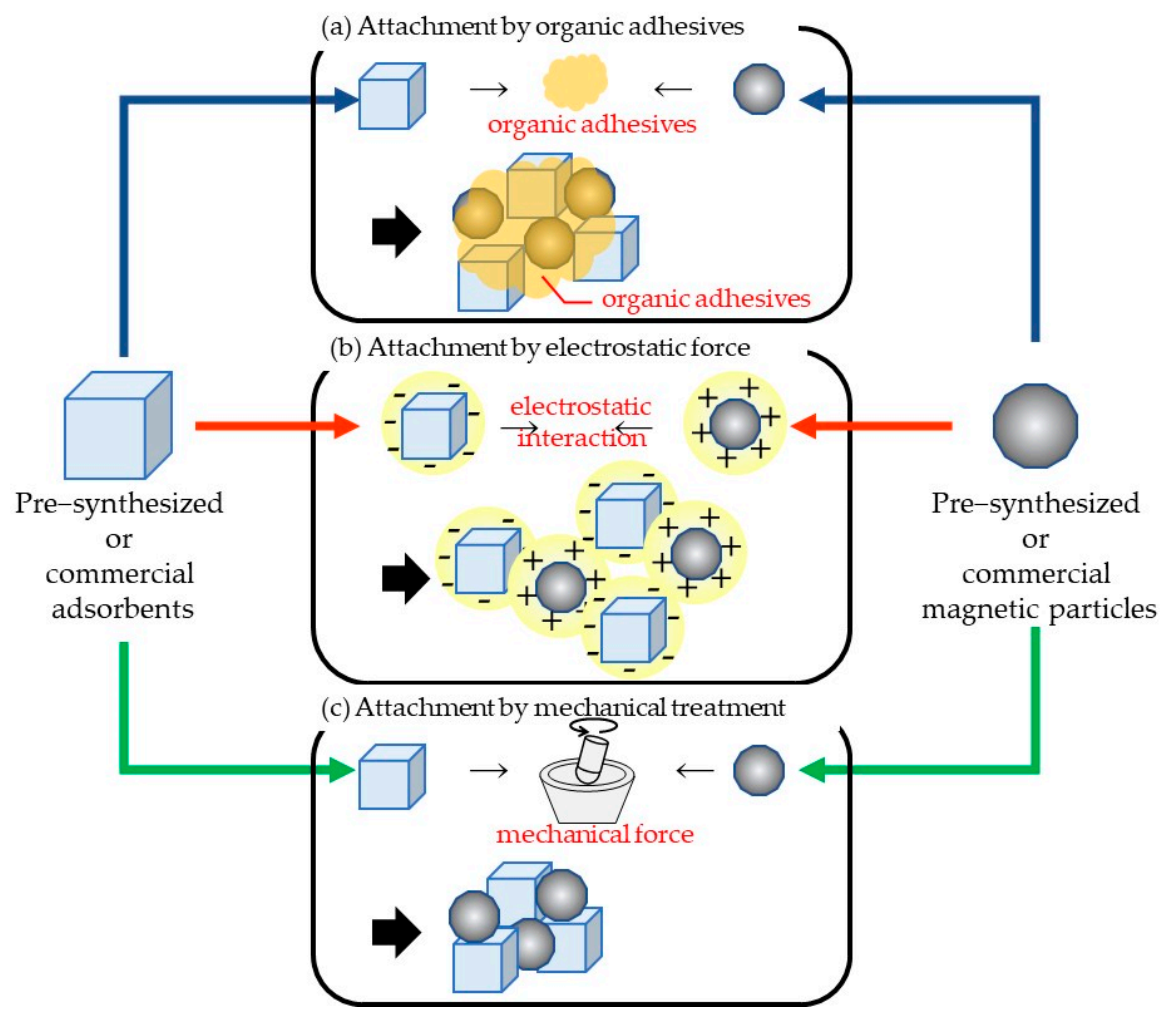

Figure 4. Illustration of attachment methods between adsorbents and magnetic particles.

\subsubsection{Attachment Using Organic Adhesives}

One of the proposed methods is to simply attach pre-synthesized magnetic particles to pre-synthesized adsorbents. In 2006, Nah et al. [67] bonded commercial zeolites (adsorbents) with commercial $\mathrm{Fe}_{3} \mathrm{O}_{4}$ (magnetic particles), by adding them into a mixture of urethane and thinner, followed by vacuum drying and ball milling. The urethane functioned as an adhesive and bonded the zeolite and magnetite. The adsorption performance of $\mathrm{Pb}(\mathrm{II})$ in magnetic zeolite, tested at $\mathrm{pH} 5.0$, was found to be $133 \mathrm{mg} / \mathrm{g}$. Unfortunately, the adsorption performance was approximately half that of the original zeolite. Polymeric materials have been widely used as adhesives. Minh and Lebedeva [45] reported the attachment of alkalitreated coffee waste to $\mathrm{Fe}_{3} \mathrm{O}_{4}$, using polyvinyl alcohol (PVA), in 2018. $\mathrm{Fe}_{3} \mathrm{O}_{4}$ was dispersed in a $2 \%$ PVA solution, heated to $80^{\circ} \mathrm{C}$, and coffee waste, pretreated with sodium hydroxide $(\mathrm{NaOH})$, was added, followed by filtering and drying. The obtained coffee waste $/ \mathrm{Fe}_{3} \mathrm{O}_{4}$ composite adsorbent showed a magnetization of $21.5 \mathrm{emu} / \mathrm{g}$ and a maximum adsorption of $227 \mathrm{mg} / \mathrm{g}$ against methylene blue, at $45^{\circ} \mathrm{C}$. Although this method is very simple and easy, the adverse effect of adhesives attached onto the adsorbent surface must be considered.

\subsubsection{Electrostatic Interaction}

Another method of attaching adsorbents to magnetic materials is electrostatic interaction. Using this method, Li et al. [37] synthesized magnetic lignin-based hollow microspheres (LHMs). The attached LHMs were prepared by self-assembly, with co-precipitated $\mathrm{Fe}_{3} \mathrm{O}_{4}$ through electrostatic interactions. Additionally, they stated that some of the $\mathrm{Fe}_{3} \mathrm{O}_{4}$ nanoparticles could also be immobilized by entering the holes of the LHMs. The adsorption capacity results showed that the magnetic LHM from larch lignin exhibited better adsorption properties for methylene blue and Rhodamine B, which were 31.23 and $17.62 \mathrm{mg} / \mathrm{g}$, than that for poplar lignin, which were 25.95 and $15.79 \mathrm{mg} / \mathrm{g}$, respectively. The saturation magnetization of magnetic LHM was about $22.7 \mathrm{emu} / \mathrm{g}$, which could be easily collected by a magnet. In an experiment on the attachment between cellulose and $\gamma-\mathrm{Fe}_{2} \mathrm{O}_{3}$ nanoparticles, Luo et al. [154] reported that iron oxide nanoparticles can be strongly attached through interaction with the electron-rich oxygen atoms of hydroxyl groups. The dependence of the 
ionic state on $\mathrm{pH}$ values implies that the adhesion strength of materials that use electrostatic interactions alone may be questionable.

\subsubsection{Liquid Self-Assembly Method}

Metin et al. $[36,155]$ prepared graphene oxide $(\mathrm{GO}) / \mathrm{Fe}_{3} \mathrm{O}_{4}$ composites using a liquid self-assembly method. The modified Hummers method and thermal decomposition of iron salt were used to prepare $\mathrm{GO}$ and $\mathrm{Fe}_{3} \mathrm{O}_{4}$, respectively. The composite, developed for Schottky diode applications, has found applications in water treatment. The composite showed a saturation magnetization of $16 \mathrm{emu} / \mathrm{g}$. The adsorption performance was measured using methylene blue (MB) as the adsorbate and showed a maximum capacity of $172.6 \mathrm{mg} / \mathrm{g}$. The adsorbent maintained an adsorption performance of $\sim 80 \%$ after five cycles. Guo and Sun [156] reported that the self-assembly method applied to graphene and FePt nanoparticles seemed to stem from the graphene's p-electron polarization, from graphene to FePt, via a possible coordination bonding, due to the close contact between the two materials. Because Metin et al. referred to their report for the self-assembly method, such polarization shall affect the attachment of the magnetic particle and adsorbent; however, further investigation is still needed to understand this mechanism.

\subsubsection{Crosslinking Reactions}

Another method used for attaching materials is the crosslinking reaction. Hosseini et al. [157] synthesized amine-functionalized magnetic core-coated carboxylated nanochitosan shells, by coupling an amine with carboxylic groups. Chitosan nanoparticles were carboxylated with citric acid (NCS- $\mathrm{COOH}), \mathrm{Fe}_{3} \mathrm{O}_{4}$ nanoparticles were functionalized with amines, using $\mathrm{N}^{1}$-(3-trimethoxysilylpropyl) diethylenetriamine $\left(\mathrm{NH}_{2}-\mathrm{Fe}_{3} \mathrm{O}_{4}\right)$. Fourier transform infrared spectroscopy (FT-IR) results indicated the successful linkage of NCS$\mathrm{COOH}$ on the $\mathrm{NH}_{2}-\mathrm{Fe}_{3} \mathrm{O}_{4}$ surface, and transmission electron microscope (TEM) images showed that a core shell structure, with $\mathrm{NH}_{2}-\mathrm{Fe}_{3} \mathrm{O}_{4}$ particles, encapsulated in the NCS$\mathrm{COOH}$ shell was formed. The authors state that high stability over a wide range of $\mathrm{pH}$ and dispersity in hydrophilic solvents enables the amphoteric $\mathrm{NH}_{2}-\mathrm{Fe}_{3} \mathrm{O}_{4} @ \mathrm{NCS}-\mathrm{COOH}$ to be a practical candidate for various purposes, including wastewater treatment. The coupling of an amine with a carboxylic acid to form an amide bond is the most popular chemical reaction, which is also used for drug discovery [158]. This technique is effective for the attachment of adsorbent and magnetic particles.

\subsubsection{Mechanical Attachment}

Others sought the possibility of attaching or embedding magnetic particles to adsorbents by mechanical treatments, such as ball milling. Galhoum [75] prepared magnetic nanocomposites of poly (glycidyl methacrylate) (PGMA) derivatives and nano-sized $\mathrm{Fe}_{3} \mathrm{O}_{4}$. $\mathrm{Fe}_{3} \mathrm{O}_{4}$ was prepared by co-precipitation, followed by heating at $80{ }^{\circ} \mathrm{C}$. High-energy ball milling of the two materials was performed at $700 \mathrm{rpm}$ for $60 \mathrm{~min}$ (including $1 \mathrm{~min}$ stop every $20 \mathrm{~min}$ ). This treatment was reported to form a core-shell magnetic nanocomposite. The grafting of aminoalkylcarboxylate and aminoalkylphosphonic ligands led to an increase in sorption capacities, due to the specific reactivity of carboxylate and phosphonate. The adsorption against U(VI) for aminoalkylcarboxylate and aminoalkylphosphonic ligandgrafted magnetic PGMA, at the optimum $\mathrm{pH}$ of $\sim 4.0$, were $122.9 \mathrm{mg} / \mathrm{g}$ and $147.0 \mathrm{mg} / \mathrm{g}$, respectively. A similar technique was adopted for magnetized polyethylene composites, by Mohebbi and Farajzadeh, using planetary ball milling [42]. They milled magnetic particles obtained from sand, with polyethylene powder at a ratio of 50:50 (\%,w/w), and then subjected them to ball milling for $1.5 \mathrm{~h}$, at a rotational speed of $900 \mathrm{rpm}$. They insisted that the heat generated by the mechanical collision melted the polyethylene, realizing a strong attachment between the two materials. The prepared composite showed a saturation magnetization of $28.43 \mathrm{emu} / \mathrm{g}$ and enabled the extraction and pre-concentration of some pesticides from fruit juices. 


\subsubsection{Unclear Attachment Methods}

Chen et al. [78] combined pre-synthesized nano $\mathrm{Fe}_{3} \mathrm{O}_{4}$ with pre-synthesized layered double hydroxide (LDH) nanocrystals, by simply mixing suspensions of the two materials, followed by sonication and collection by a magnet. The LDH was prepared by hydrothermal treatment, and $\mathrm{Fe}_{3} \mathrm{O}_{4}$ was prepared by co-precipitation. This nanohybrid magnetic adsorbent showed a high performance of $505 \mathrm{mg} / \mathrm{g}$ against Congo Red (based on LDH). The magnetic adsorbent showed a quick uptake of $96 \%$ of the capacity within 5 min and maintained a capacity of over $80 \%$ of the initial performance after four cycles. Similarly, Fungaro et al. $[69,70,80]$ prepared a composite of zeolite, synthesized from fly ash and $\mathrm{Fe}_{3} \mathrm{O}_{4}$, obtained from co-precipitation. The zeolite was slowly added to a suspension of $\mathrm{Fe}_{3} \mathrm{O}_{4}$ particles and subsequently washed, milled, and dried. The resulting product was found to be easily attracted by a magnet; however, the adhesion force between the two materials was not clarified. Adsorption of $\mathrm{Zn}$ (II) [69], U(IV) [70], and two types of dyes, reactive orange 16 and indigo carmine [80], were tested. All adsorbates showed Langmuirtype adsorption, with maximum capacities of 30,22.4, 1.06, and $0.583 \mathrm{mg} / \mathrm{g}$, respectively. Bessa et al. [71] also synthesized magnetic zeolite by simply mixing $\mathrm{Fe}_{3} \mathrm{O}_{4}$, prepared by precipitation/partial oxidation, and hydrothermally synthesized zeolites $\mathrm{A}$ and $\mathrm{P}$ at a 1:3 mass ratio, macerated, and dispersed in distilled water, at $80{ }^{\circ} \mathrm{C}$ for $1 \mathrm{~h}$. The saturated magnetization was 25.5 and $\sim 17.5 \mathrm{emu} / \mathrm{g}$ and adsorption performance against $\mathrm{Ca}$ (II) was 54 and $51 \mathrm{mg} / \mathrm{g}$ for zeolite A and P, respectively. Gaffer et al. [159] further extended this technique and attached chitosan as a secondary adsorbent on a magnetic adsorbent, to form magnetic zeolite-natural polymer composites. The $\mathrm{Cr}(\mathrm{VI})$ removal efficiency was $98 \%$ at $\mathrm{pH}$ 2, when the initial $\mathrm{Cr}(\mathrm{VI})$ concentration was $200 \mathrm{mg} / \mathrm{L}$. Many researchers [68-75,80] utilize this technique, but the detailed adhesion mechanism needs further clarification.

\subsection{Synthesis of Magnetic Particles on Adsorbents}

Many different materials, including active carbon [102], carbon nanofiber aerogels [108], nanotubes [92,95], reduced graphene oxide [103], LDH [159], bentonite [100], and MoS 2 [101], have been studied as potential adsorbents. However, these adsorbents cannot be easily separated after utilization, which restricts their application and development. The introduction of magnetic particles onto adsorbents could be an effective method to facilitate facile separation. Therefore, researchers have attempted to develop a series of methods to synthesize magnetic particles on pre-synthesized adsorbents. A summary of typical magnetic adsorbents with synthesis techniques and properties has been presented in Table 1.

\subsubsection{Co-Precipitation}

This common method can be used to synthesize magnetic particles on adsorbents. During the co-precipitation process, the magnetic nanoparticles are incorporated with extensively investigated materials, such as active carbon, nanotubes, reduced graphene oxide, zeolite, $\mathrm{LDH}$, and $\mathrm{MoS}_{2}$. Oliveira et al. [28] reported the introduction of maghemite into commercial $\mathrm{NaY}$ zeolite, to produce a novel adsorbent. The bulk magnetization was converted from the original value of 18 to $33 \mathrm{~J} / \mathrm{T} \cdot \mathrm{kg}$. Uniformly distributed small nanoparticles $(3-6 \mathrm{~nm})$ can also be obtained in a cubic zeolite matrix $[160,161]$. Despite the direct mixing of the precursors with zeolite, 1-butyl-3-methylimidazolium tetrachloroferrate ([bmim $\left.] \mathrm{Cl} / \mathrm{FeCl}_{3}\right)$ ionic liquid has been used to immobilize magnetic $\mathrm{NaY}$ zeolite. However, the magnetic particles, by occupying the entrance of the zeolite porous structure, prevent the diffusion of pollutants, especially macromolecules or organic dyes [162].

Humic acid, coated on the surface of magnetite as a sorbent, is an environmentally friendly material, and the structure of the magnetite core, with a humic acid shell, has better adsorption performance in an acid condition [81]. Other surface modifiers, such as oleic acid [89], functionalized chitosan [85,86], polyacrylic acid [40], lignosulfonate [84], and activated sericite clay [98], to some extent, could enhance the dispersion of magnetic nanocomposites, because they are widely spaced. In this way, the size of the nanocomposites can be controlled on a small scale, lower than $10 \mathrm{~nm}$. 
Recently, more complex hybrid adsorbents have been synthesized using the coprecipitation method. Wan et al. [91] reported the results of a humic acid/L-cysteinecodecorated magnetite that has complex properties, resulting from functional groups, ion exchange, and negatively charged surfaces. In another study, Amini et al. [87] reported a novel composite, $\mathrm{GO} / \mathrm{Fe}_{3} \mathrm{O}_{4} / \mathrm{OPO}_{3} \mathrm{H}_{2} / \mathrm{PCN}-222$, that can extract $\mathrm{U}(\mathrm{VI})$ in $3 \mathrm{~min}$, with a capacity of $416.7 \mathrm{mg} / \mathrm{g}$. It took three steps to prepare the adsorbents; therefore, large-scale production was unfeasible and not cost-effective. It is worth noting that during this process, some particles were first nucleated into clusters and then aggregated together. The support materials can provide a large surface area for adhesion; however, the adhesion largely involves physical bonding, which can trigger problems, such as leaching and desorption.

\subsubsection{Solvothermal}

The solvothermal/hydrothermal method provides a simple, direct, and low-temperature method of obtaining nanoparticles with a narrow dispersion and includes an alternative method of calcination at mild temperatures, to promote crystallization. After heating in a Teflon-lined stainless steel autoclave at $200{ }^{\circ} \mathrm{C}$, a crystalline cubic spinel structure of $\mathrm{Fe}_{3} \mathrm{O}_{4}$ was successfully obtained on the surface of the mesoporous carbon in the composite [104]. In another similar study, $\mathrm{Fe}_{3} \mathrm{O}_{4} / \gamma-\mathrm{Fe}_{2} \mathrm{O}_{3}$ was loaded with active carbon, smaller in size [96]. A titanium dioxide-coated magnetic hollow mesoporous silica sphere, with a high surface area, produced by Wu et al. [163], could be used to efficiently and quickly capture phosphopeptides from peptide mixtures.

One-dimensional electrospun nanofibers, with large specific surface areas and high porosities, are connected to each other, making it easy to extract them from water. Liu et al. [105] loaded cubic phase magnetite particles on polyacrylonitrile fibers, through a "two-step" process-electrospinning first and solvothermal next-without changing the morphology and structure of the spinning (Figure 5). Charpentier et al. [39] improved the chitosan-doped $\mathrm{Fe}_{3} \mathrm{O}_{4}$ adsorbent, using carboxymethyl chitosan. The colloidal magnetic nanoparticles were synthesized via a "one-step" versatile solvothermal method and a simultaneous removal of $\mathrm{Pb}(\mathrm{II}), \mathrm{Cu}(\mathrm{II})$, and $\mathrm{Zn}$ (II) was achieved, owing to the chain flexibility and high concentration of chelating groups from carboxymethyl chitosan. Size-controlled magnetic nanoparticles can be synthesized by a solvothermal method, using surfactants. These protective agents can prevent particles from aggregating. However, the size can range from 10 to $200 \mathrm{~nm}$, and the interaction between surfactants and magnetic particles needs further research. 


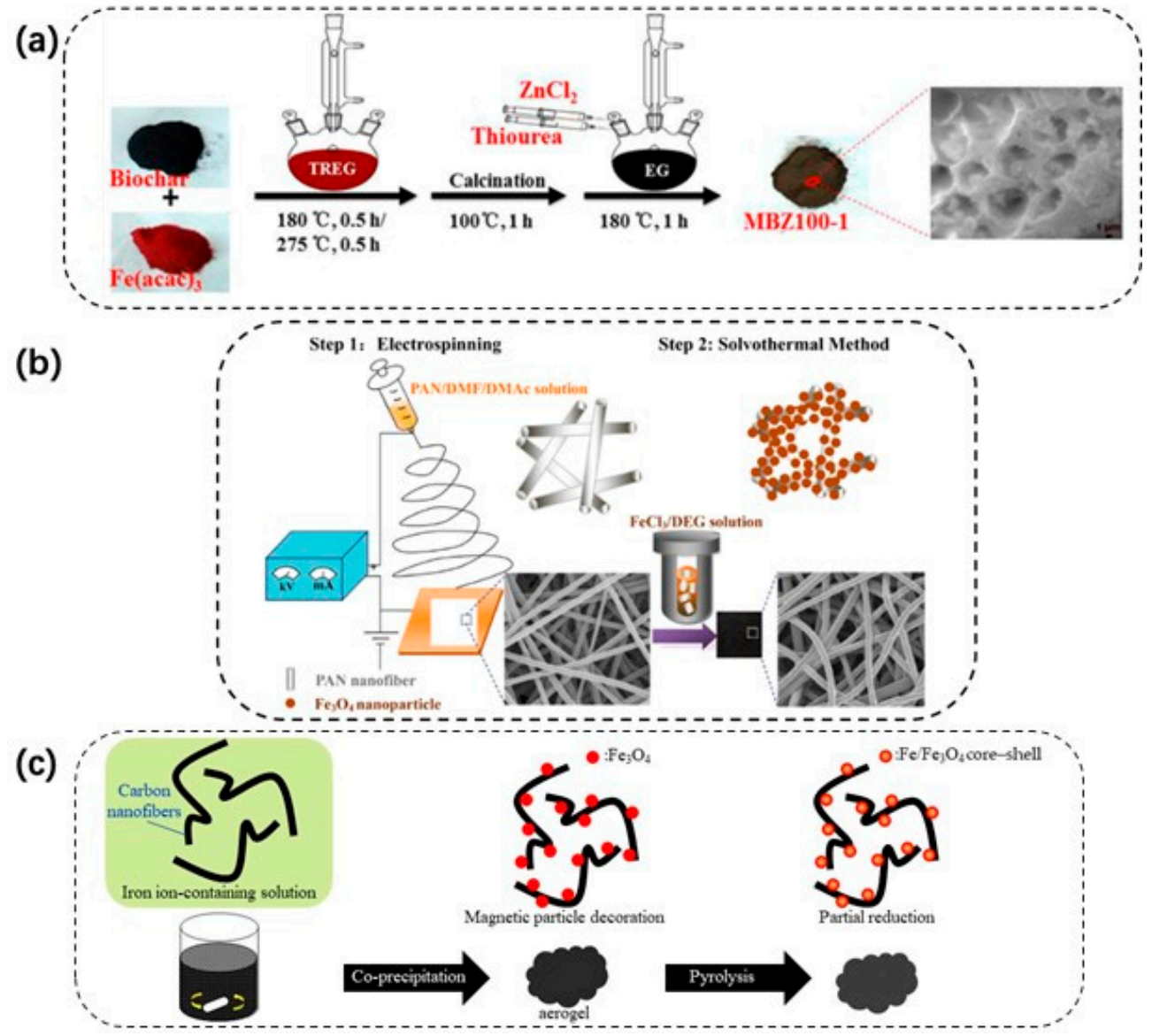

Figure 5. Representative preparation procedures of (a) magnetic biochar/ZnS, (b) $\mathrm{Fe}_{3} \mathrm{O}_{4} / \mathrm{PAN}$ composite nanofibers (NFs), and (c) magnetic carbon fiber aerogels. (Reprinted with permission from (a) ACS Sustainable Chem. Eng. 2015, 3, 1, 125-132 Ref. [164] Copyright (C 2022 American Chemical Society and (b) ACS Appl. Mater. Interfaces 2015, 7, 14573-14583 Ref. [105] Copyright (C) 2022 American Chemical Society.).

\subsubsection{Thermal Decomposition}

Thermal decomposition is another facile approach for obtaining efficient adsorbents. Nanoparticles are formed in situ during the heating process and used to absorb directly, without any post-treatment. Recently, a new type of calcined magnetite-activated carbon/MgAl-LDH was prepared and characterized. It effectively removed low-concentration iodide ions $\left(\mathrm{I}^{-}\right)$, through the "memory effect" [82]. The magnetic adsorbent and layered double oxide were prepared in the same step, making it an efficient and convenient synthesis method. Although thermal decomposition can result in a uniform size distribution and highly crystallized magnetite, it is highly energy intensive. Other essential one-pot methods should be investigated in future studies. The introduction of magnetic particles on adsorbents may occupy the active sites of adsorbents, leading to a decrease in the adsorption properties. These issues should be well addressed for practical applications.

\subsection{Synthesis of Adsorbents on Magnetic Particles}

Magnetic adsorbents can be prepared in a route opposite to the one described in Section 2.3 , by synthesizing the adsorbent onto magnetic materials. In most cases, these are prepared by synthesizing adsorbents in the presence of pre-synthesized magnetic particles. The combination of magnetic particles with inorganic or organic adsorbents/ion exchangers was carried out in different ways, depending on the target adsorbent (Figure 6). Although $\mathrm{Fe}_{3} \mathrm{O}_{4}$, pre-synthesized by conventional co-precipitation or solvothermal methods, is the 
most commonly used magnetic particle, some researchers have used commercialized magnetite for convenience, with an optimal particle size.

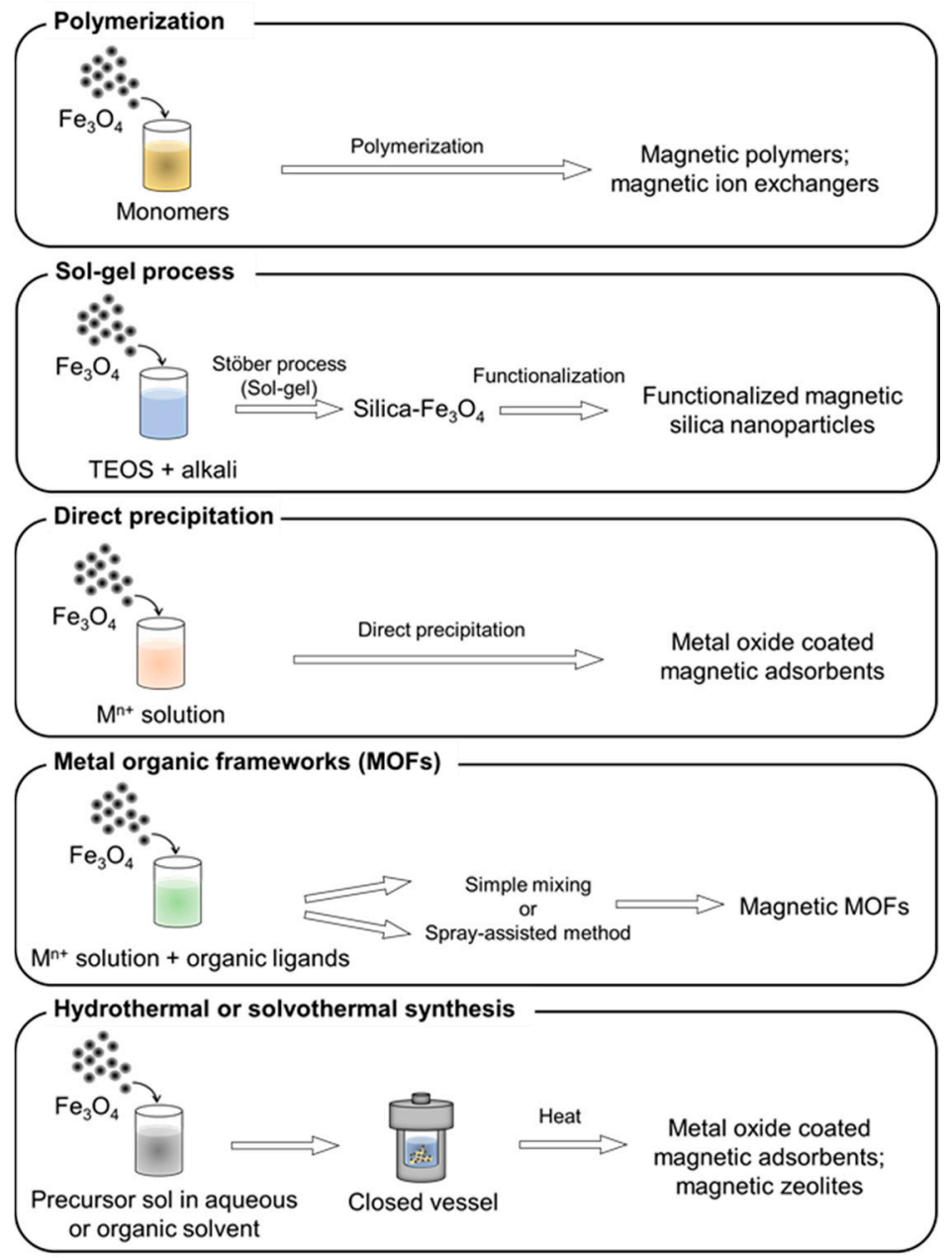

Figure 6. Brief procedures of conventional synthesis methods for adsorbents on magnetic particles.

\subsubsection{Polymerization}

Polymeric substances, applied as adsorbents or ion exchangers, can be directly grafted onto magnetic iron oxide surfaces. Polymer-coated $\mathrm{Fe}_{3} \mathrm{O}_{4}$ is prepared by polymerization, depending on the target polymer. A simple protocol, such as suspension of a mixture of $\mathrm{Fe}_{3} \mathrm{O}_{4}$ and monomers by continuous stirring, was used for grafting at room temperature, under cooling, or at an elevated temperature. For example, Bolto et al. [24] synthesized polyacrylic acid-grafted $\mathrm{Fe}_{3} \mathrm{O}_{4}$ as an ion exchanger in wastewater treatment; Wei et al. [134] presented a polymer-coated $\mathrm{Fe}_{3} \mathrm{O}_{4}$ by the self-polymerization of dopamine on $\mathrm{Fe}_{3} \mathrm{O}_{4}$ $\mathrm{COOH}$ at room temperature, for organic dye adsorption. The poly(m-phenylenediamine) layer provided predominant amino groups as adsorption sites for $\mathrm{Cr}(\mathrm{VI})$, resulting in a fivefold increase in the maximum $\mathrm{Cr}(\mathrm{VI})$ adsorption capacity, compared to that of bare $\mathrm{Fe}_{3} \mathrm{O}_{4}$ [113]. Another example of grafting polymers at a low temperature is the oxidative copolymerization of microbial extracellular polymeric substances (EPS) on $\mathrm{Fe}_{3} \mathrm{O}_{4}$, via interaction between $\mathrm{Fe}$ and $\mathrm{O}$ and $\mathrm{C}=\mathrm{N}$ on EPS, by continuous stirring at $0{ }^{\circ} \mathrm{C}$ [124]. The magnetic polymer was used for the adsorption of $\mathrm{Ag}(\mathrm{I})$ and showed a slightly improved maximum adsorption capacity compared to EPS, owing to a higher surface area. Another polymer, sulfonated polystyrene, required an elevated temperature to polymerize on $\mathrm{Fe}_{3} \mathrm{O}_{4}$, which was then tested for Se adsorption in water samples. Sulfonated polystyrene- $-\mathrm{Fe}_{3} \mathrm{O}_{4}$ was used as a detection tool by magnetic immobilization in a microchannel, to perform on-chip magnetic solid-phase microextraction, with subsequent instrumental analysis [165]. 


\subsubsection{Sol-Gel}

The sol-gel process is widely used for coating silica shells on $\mathrm{Fe}_{3} \mathrm{O}_{4}$ cores, to obtain magnetic core-shell structures. The silica shell can prevent the possible loss of magnetism, due to oxidation of the magnetic oxide core, and can be modified with various functional groups. The Stöber method, a modified sol-gel process for preparing silica, is commonly used [166]. The process is initiated by the hydrolysis of tetraethyl orthosilicate (TEOS) in the presence of ethanol, water, and ammonia, with subsequent co-condensation of silicic acid, to form silica. Sodium silicate can be used for the precipitation of silica in acidic media. In the presence of the hydroxy groups on $\mathrm{Fe}_{3} \mathrm{O}_{4}$, a silica layer can be formed on the surface of $\mathrm{Fe}_{3} \mathrm{O}_{4}$ by continuous stirring, under an $\mathrm{N}_{2}$ atmosphere. Some additives, such as glycerol, were used as porogens, in order to increase the pore size of silica [167], contributing to the occlusion of $\mathrm{Fe}_{3} \mathrm{O}_{4}$ [122]. Further functionalization of silica with various silane coupling agents has been reported. Octadecyl or $\mathrm{C} 18$, a long-chain hydrocarbon group, was grafted onto silica- $\mathrm{Fe}_{3} \mathrm{O}_{4}$ through alkylation. Jiang et al. [129] used dimethyl octadecyl chlorosilane as a silane coupling agent, to functionalize an ultrafine silica- $\mathrm{Fe}_{3} \mathrm{O}_{4}$ simple core-shell with C18, for the adsorption of Sudan dyes in water. In another study, Li et al. [139] synthesized C18-functionalized interior pore-wall mesoporous silica, for the adsorption of phthalates in water, by mixing $\mathrm{Fe}_{3} \mathrm{O}_{4}$ with TEOS and n-octadecyltriethoxysilane. Here, the cationic surfactant cetyl trimethylammonium bromide (CTAB) was employed as the interior wall template. Partial silanol groups of silica were shielded from the C18functionalized interior by ion pairing with CTAB. Finally, CTAB was removed, and the interior wall structure of $\mathrm{C} 18$-functionalized silica was obtained. In this manner, the adsorbents had greater dispersibility in water than the simple core-shell structure. These two types of $\mathrm{C} 18$-functionalized silica- $\mathrm{Fe}_{3} \mathrm{O}_{4}$ showed good magnetic separability, with high adsorption performance, and were utilized as adsorbents in the magnetic solid-phase extraction of organic pollutants. Amino is another widely employed functional group that provides electrostatic interactions with ionic adsorbate species. Huang et al. [112] functionalized silica- $\mathrm{Fe}_{3} \mathrm{O}_{4}$ with an amino group, by simply refluxing pre-synthesized silica- $\mathrm{Fe}_{3} \mathrm{O}_{4}$ with 3 -aminopropyl trimethoxysilane (APTMS) for $8 \mathrm{~h}$. The obtained product had a microspherical shape and high saturation magnetization $\left(\mathrm{M}_{\mathrm{S}}=60.6 \mathrm{emu} / \mathrm{g}\right)$, which was easily trapped inside a knotted tube, for the online speciation of $\mathrm{Cr}(\mathrm{VI}, \mathrm{III})$ in water samples. Zhang et al. [117] prepared the same type of magnetic amino adsorbent and found that the amount of APTMS used affected the morphology of the product. An excess amount of APTMS was found to accelerate the hydrolysis rate of TEOS, due to its basicity, resulting in faster precipitation of silica. The faster precipitation led to an incomplete coating of silica on $\mathrm{Fe}_{3} \mathrm{O}_{4}$. However, well-coated spherical core-shell particles have been used for $\mathrm{Pb}$ (II) removal from water. Wang et al. [127] synthesized acid-resistant magnetic adsorbents for the removal of $\mathrm{Sb}$ (III) from strong acid solutions. The adsorbent contains an $\mathrm{Fe}_{3} \mathrm{O}_{4}$ core, protected by a multilayer shell, including silica, and a hydrophobic methyl group, terminated with amino methylene phosphonic acid as the adsorption site. The adsorbents showed high $\mathrm{Sb}$ (III) adsorption performance in strong acid media, in the presence of foreign ions. The amino groups can be further modified with various active sites for the removal of different adsorbates. For example, Huang et al. prepared amino-silica$\mathrm{Fe}_{3} \mathrm{O}_{4}$ and modified it with various functional groups, such as sulfur-doped amide-linked organic polymers for $\mathrm{Hg}$ (II) adsorption [123], covalent organic frameworks (COFs) for diclofenac sodium adsorption [141], and recently sulfonic acid-functionalized covalent organic polymers for the removal of malachite green [136]. These functional adsorbents showed satisfactory adsorption performance and a good magnetic response, with $\mathrm{M}_{\mathrm{s}}$ in the range $15-20.2 \mathrm{emu} / \mathrm{g}$. Functionalized silica- $\mathrm{Fe}_{3} \mathrm{O}_{4}$ adsorbents for the removal of multielements have been developed. Examples include amino benzyl EDTA, immobilized on carboxylic-coated silica- $\mathrm{Fe}_{3} \mathrm{O}_{4}$, for chelating $\mathrm{Cu}(\mathrm{II}), \mathrm{Co}(\mathrm{II}), \mathrm{Cd}(\mathrm{II})$, and $\mathrm{Pb}(\mathrm{II})$ in water [168] and benzyl group-functionalized chitosan, modified on silica- $\mathrm{Fe}_{3} \mathrm{O}_{4}$, to remove organic dyes [133]. Surfactants have been used for the surface modification of silica- $\mathrm{Fe}_{3} \mathrm{O}_{4}$ because they possess both hydrophilic and hydrophobic moieties. Karatapanis et al. [137] utilized a 
cationic surfactant, cetylpyridinium bromide ( $\mathrm{CPBr}$ ), to modify the surface of silica- $\mathrm{Fe}_{3} \mathrm{O}_{4}$. The positive charge of $\mathrm{CPBr}$ attracted a negative charge on silica, in the $\mathrm{pH}$ range of 6 to 9, whereas the hydrophobic tails of $\mathrm{CPBr}$ served as the adsorption sites. The adsorbents were tested for the adsorption of six heavy metal ions in water samples, after complexation with 8-hydroxyquinoline. Sodium dodecyl sulfate (SDS), an anionic surfactant, is another example of surface modification with surfactants. Adivi et al. [140] prepared a magnetic adsorbent for the removal of phenazopyridine, a cationic drug, from water samples, by initially functionalizing silica- $\mathrm{Fe}_{3} \mathrm{O}_{4}$ with amino groups, with subsequent electrostatic binding to the negative heads of SDS. The hydrophobic tails of these SDS molecules interacted with the surrounding SDS tails and were finally caged in agarose. Negative charges in SDS and the hydroxy groups on agarose acted as adsorption sites for phenazopyridine. Recently, silica, apart from serving as a protection layer or functionalization bridge, has also been used as a hard template for the crystallization of titanium oxide-based nanosheets. Zhao et al. [126] synthesized amorphous $\mathrm{TiO}_{2}$ on silica- $\mathrm{Fe}_{3} \mathrm{O}_{4}$, using the Stöber method. Then, the silica layer was removed by dissolution in a strong alkali solution, followed by recrystallization of the $\mathrm{H}_{2} \mathrm{Ti}_{2} \mathrm{O}_{5}$ nanosheet, by redissolving $\mathrm{TiO}_{2}$ in diluted hydrochloric acid. After calcination at $400{ }^{\circ} \mathrm{C}$, the crystals became flower-like nanosheets. Finally, amidoxime was grafted onto the magnetic flower-like nanosheet for the removal of $U(V I)$ from seawater samples. The adsorbents, although obtained from a complicated process, showed good magnetic response, with an $\mathrm{M}_{\mathrm{s}}$ of $15.19 \mathrm{emu} / \mathrm{g}$.

\subsubsection{Direct Precipitation}

The precipitation of inorganic compounds on magnetic particle surfaces was employed to prepare magnetic inorganic adsorbents. The adsorbents precipitate and attach to the surface of the magnetic particles, by simple agitation. Wang et al. [114] utilized the Stöber method to precipitate aluminum hydroxide $\left(\mathrm{Al}(\mathrm{OH})_{3}\right)$ on the surface of $\mathrm{Fe}_{3} \mathrm{O}_{4}$, by dispersing $\mathrm{Fe}_{3} \mathrm{O}_{4}$ particles with aluminum isopropoxide, at room temperature. Alumina-coated $\mathrm{Fe}_{3} \mathrm{O}_{4}$ was obtained by calcination of the precipitate, collected at $500{ }^{\circ} \mathrm{C}$, and subsequently trapped in a microcolumn, using an Nd-Fe-B magnet. It was then used as a solid support for SDS to further bind with 1-(2-pyridylazo)-2-naphthol as the adsorption site for $\mathrm{Co}(\mathrm{II})$, in a lab-on-valve sequential injection analysis system. Amorphous calcium silicate $\left(\mathrm{CaSiO}_{3}\right)$ and manganese dioxide $\left(\mathrm{MnO}_{2}\right)$-coated $\mathrm{Fe}_{3} \mathrm{O}_{4}$ were prepared separately by Briso et al. [169], who evaluated it for the removal of multi-elements from acidic mine water. They found that approximately $90 \%$ of the heavy metal ions were removed by using only $\mathrm{CaSiO}_{3}$-coated $\mathrm{Fe}_{3} \mathrm{O}_{4}$ in the first step, whereas the $\mathrm{MnO}_{2}$-coated $\mathrm{Fe}_{3} \mathrm{O}_{4}$ decreased the concentration of toxic metal ions to below the permissible contamination levels, in the second step. In a more recent study, the precipitation of lanthanum hydroxide $\left(\mathrm{La}(\mathrm{OH})_{3}\right)$ on the surface of $\mathrm{Fe}_{3} \mathrm{O}_{4}$ was accomplished on a kilogram-scale, by Ahmed et al. [109]. The preparation was performed in a tank, with continuous stirring, and using sodium hydroxide as the precipitating agent, at $50{ }^{\circ} \mathrm{C}$. After collection, the adsorbents showed a magnetic separation rate of $98 \%$ within $3 \mathrm{~min}$ and were evaluated for phosphate adsorption at batch scale and pilot plant scale, using river water samples. Phosphate adsorption occurs via electrostatic interaction with protonated hydroxide groups and complexation with La. A removal efficiency of $40 \%$ was achieved at the pilot plant scale, which is approximately half that of the batch scale.

\subsubsection{Metal Organic Frameworks (MOFs)}

MOFs are utilized as adsorbents and combined with magnetic particles to improve separation performance. A zeolitic imidazole framework (ZIF-8) was prepared on the surface of $\mathrm{Fe}_{3} \mathrm{O}_{4}$, pre-synthesized via a solvothermal method, in the presence of citric acid. $\mathrm{Fe}_{3} \mathrm{O}_{4}$ was dispersed in a mixture of zinc nitrate and imidazole at $70{ }^{\circ} \mathrm{C}$ [131] or pretreated with polystyrene sulfonate, before mixing with the ZIF-8 precursors at room temperature [119]. MOF formation is initiated by the interaction between $\mathrm{Zn}$ (II) and carboxylate groups in $\mathrm{Fe}_{3} \mathrm{O}_{4}$, followed by coordination of $\mathrm{Zn}$ (II) with imidazole. Morphology studies of ZIF-8 
modified $\mathrm{Fe}_{3} \mathrm{O}_{4}$ prepared by these two synthesis processes revealed an obvious core-shell structure. Their adsorption performance was evaluated by the adsorption of methylene blue [131], $\mathrm{Pb}(\mathrm{II})$, and $\mathrm{Cu}(\mathrm{II})$ [119] in water. Another type of magnetic MOF was developed for methylene blue adsorption. $\mathrm{Fe}_{3} \mathrm{O}_{4}$ and $\mathrm{TiO}_{2}$, as photocatalysts, were incorporated into $\mathrm{Cu}_{3}(1,3,5 \text {-benzenetricarboxylate })_{2}$ or HKUST-1, via a spray-assisted synthetic process [130]. This method is one of the fast MOF synthesis methods [170]. $\mathrm{Fe}_{3} \mathrm{O}_{4}$ and $\mathrm{TiO}_{2}$ particles were pre-mixed with the HKUST-1 mother solution, before spraying through two heated nozzles. The product was collected, washed, and dried before use. The process is fast, but the crystallinity of the product obtained by the spray-assisted process was found to be lower than that of the batch process, and the incorporation of $\mathrm{Fe}_{3} \mathrm{O}_{4}$ particles was quite non-uniform. The adsorbents had much lower magnetic saturation than that of bare $\mathrm{Fe}_{3} \mathrm{O}_{4}$, due to the thickness of HKUST-1, but were separable from solutions using a simple magnet. However, the incorporated $\mathrm{TiO}_{2}$ did not significantly contribute to methylene blue degradation.

\subsubsection{Hydrothermal and Solvothermal}

Hydrothermal and solvothermal methods have been widely used for the preparation of nanoparticles, especially metal oxides. When water is used as the solvent, the process is termed hydrothermal; when other solvents are used, it is termed solvothermal. The synthesis is performed in a closed reaction vessel, above the critical temperature of solvents, in the range of $130-250^{\circ} \mathrm{C}$, and high pressure $(0.3-4.0 \mathrm{Mpa})[8,171]$. Zeolites, a group of aluminosilicate compounds that are widely used as adsorbents in environmental remediation, have been combined with magnetic particles, to improve the performance of adsorbents. The preparation of magnetic zeolites using conventional hydrothermal methods with different frameworks has been reported, including P zeolite [110], ZSM5 [115], NaA [118], and mordenite [111]. The synthesis begins by mixing $\mathrm{Fe}_{3} \mathrm{O}_{4}$ with a zeolite precursor solution, before transferring it to a stainless steel autoclave, followed by crystallization at specific temperatures, for a determined amount of time. In most cases, $\mathrm{Fe}_{3} \mathrm{O}_{4}$ and zeolite particles are attached to each other on the surface. The ability of the synthesized magnetic zeolites to adsorb monovalent and divalent metal ions in water was evaluated. Another metal oxide, $\mathrm{MnO}_{2}$, was also prepared by a hydrothermal process, around the $\mathrm{Fe}_{3} \mathrm{O}_{4}$ core, to obtain a core-shell structure, for the removal of $\mathrm{Cu}$ (II) $\mathrm{Cd}$ (II), $\mathrm{Zn}(\mathrm{II})$, and $\mathrm{Pb}$ (II) [27]. The hydrothermal method was applied to synthesize magnetic graphene oxide with an LDH composite, for the first time, by Zhang et al. [116]. Before being subjected to the hydrothermal process, hydroxides of magnesium and aluminum were pre-milled, using ball milling, and were mixed with graphene oxide and $\mathrm{Fe}_{3} \mathrm{O}_{4}$. This process is called the mechano-hydrothermal method. During the hydrothermal process, LDHs were formed with the subsequent formation of the magnetic composite. LDHs can induce the precipitation of other metal ions. Carboxylic groups and aromatic rings in graphene oxide are attractive to metal ions and organic compounds, respectively. Therefore, the composite showed simultaneous adsorption of $\mathrm{Pb}$ (II) and 2,4-dichlorophenoxy acetic acid, a type of pesticide, in water. Magnetic carbon-based adsorbents were prepared using a conventional hydrothermal method. Lai et al. [125] pre-mixed sucrose solution as the carbon source with $\mathrm{Fe}_{3} \mathrm{O}_{4}$, before the hydrothermal treatment. The collected product was then refluxed with $\mathrm{NaOH}$. The FT-IR analysis showed the partial carbonization of sucrose, to obtain carbon, whereas carboxylate and f-lactonic groups were mostly found on the surface. These functional groups were able to coordinate with U(VI); therefore, magnetic adsorbents were used to remove U(VI) from water. The solvothermal method was used to directly functionalize $\mathrm{C} 18$ on $\mathrm{Fe}_{3} \mathrm{O}_{4}$ without surface modification, using silica. Zhang et al. [138] prepared $\mathrm{C} 18-\mathrm{Fe}_{3} \mathrm{O}_{4}$ by dispersing $\mathrm{Fe}_{3} \mathrm{O}_{4}$ in ethanol and toluene, before adding octadecyltriethoxysilane. The solvothermal process was performed at $120^{\circ} \mathrm{C}$ for $12 \mathrm{~h}$. After collection, the $\mathrm{C} 18-\mathrm{Fe}_{3} \mathrm{O}_{4}$ was caged in a hydrophilic barium-alignate polymer, for magnetic solid-phase extraction of polycyclic aromatic hydrocarbons and phthalate esters from water. This is an example application of magnetic adsorbents in sample preparation, prior to instrumental analysis. MOFs can also be produced by a 
solvothermal process in the presence of $\mathrm{Fe}_{3} \mathrm{O}_{4}$. Far et al. [132] modified $\mathrm{Fe}_{3} \mathrm{O}_{4}$, prepared by the co-precipitation method, with zirconium-based MOFs (coded UiO-66). $\mathrm{Fe}_{3} \mathrm{O}_{4}$ was dispersed in N,N-dimethylformamide, in the presence of UiO-66 precursors, before the solvothermal process. The obtained particles were then modified with a polypropylene imine dendrimer by continuous stirring. The final product was found to aggregate with a non-uniform shape and size and showed soft ferromagnetism, with an $\mathrm{M}_{\mathrm{s}}$ of $10.5 \mathrm{emu} / \mathrm{g}$. The polypropylene imine dendrimer was used as an adsorption site for the evaluation of anionic dye removal in wastewater treatment plants.

\section{Recent Advancements in Synthesis Methods of Magnetic Adsorbents}

Although conventional methods continue to be used in a variety of studies, advanced techniques are being developed, some of which are based on conventional techniques (Figure 7). In this section, recent advancements in synthesis techniques are discussed. Advanced magnetic adsorbents in the removal of various organic and inorganic pollutants from water, according to their categorized groups, with their synthesis methods, adsorption performances, and magnetic performances are summarized in Table 2.

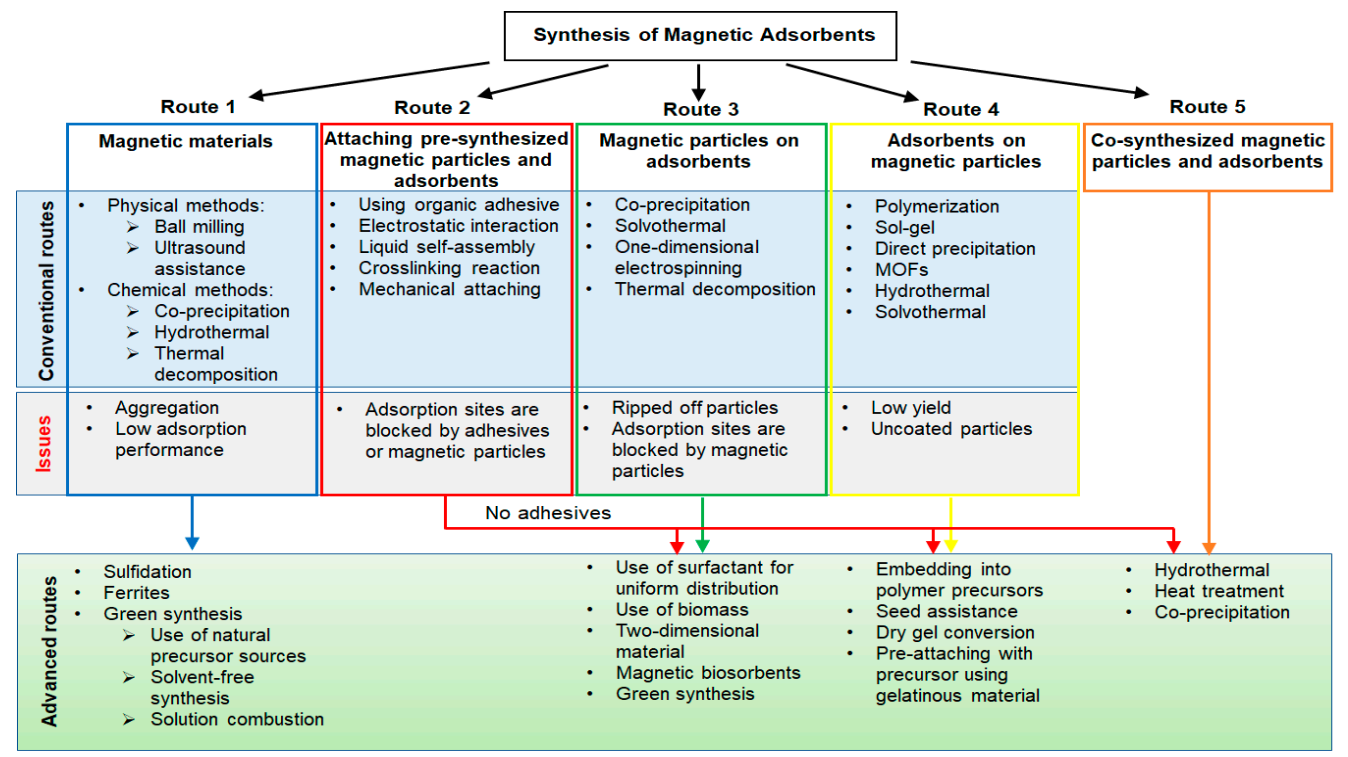

Figure 7. Schematic classification of the conventional synthesis methods of magnetic adsorbents covered in this review with their issues and advancements.

The improvements of these new methods make conventional synthesis less energy intensive, more efficient, and simpler, while maintaining or increasing the adsorption performance in most cases. These approaches are also important from the viewpoint of cost. The addition of magnetic properties to adsorbents increases the cost of their synthesis. However, previous reports show that the economic performance of magnetic adsorbents is already competitive in some limited cases. Oladipo et al. [172] reported that magnetic hybrids have a comparative advantage, regarding operational cost (including energy input and sludge formation), separation after spent, regeneration, and reuse in the removal of boron. Reshadi et al. [55] also claimed that rather expensive, but reusable, magnetic adsorbents have become more cost-effective than low-cost, single-use, conventional adsorbents. Therefore, magnetic adsorbents developed by the aforementioned advanced methods are expected to be competitive in wider applications. 
Table 2. Advanced synthesis methods of magnetic adsorbents, and their performance on adsorption of organic and inorganic pollutants in water.

\begin{tabular}{|c|c|c|c|c|c|}
\hline Adsorbents & Synthesis Method & Magnetic Properties & Pollutant(s) & $\begin{array}{l}\text { Adsorption or } \\
\text { Removal Performance }\end{array}$ & Reference \\
\hline \multicolumn{6}{|c|}{ Advanced synthesis of magnetic materials as adsorbents } \\
\hline Sulfur-doped $\mathrm{Fe}_{3} \mathrm{O}_{4}$ & $\begin{array}{l}\text { Simple mixing and } \\
\text { sintering }\end{array}$ & $\mathrm{M}_{\mathrm{s}}=37.1 \mathrm{emu} / \mathrm{g}$ & $\mathrm{As}(\mathrm{V})$ & $\mathrm{q}_{\mathrm{m}}=58.38 \mathrm{mg} / \mathrm{g}$ & [48] \\
\hline $\begin{array}{l}\text { Dendrimerlike } \\
\text { biosorbent- } \mathrm{Fe}_{3} \mathrm{O}_{4} / \mathrm{Fe}_{2} \mathrm{O}_{3} \text { based } \\
\text { on orange peel waste }\end{array}$ & Co-precipitation & Not reported & $\mathrm{As}(\mathrm{V})$ & $\mathrm{q}_{\mathrm{m}}=81.3 \mathrm{mg} / \mathrm{g}$ & [173] \\
\hline Sulfur-doped $\mathrm{Fe}_{3} \mathrm{O}_{4}$ & $\begin{array}{l}\text { Simple mixing and } \\
\text { sintering }\end{array}$ & $\mathrm{M}_{\mathrm{s}}=32.97 \mathrm{emu} / \mathrm{g}$ & $\mathrm{Pb}(\mathrm{II})$ & $\mathrm{q}_{\mathrm{m}}=500 \mathrm{mg} / \mathrm{g}$ & [47] \\
\hline$\beta$-cyclodextrin-stabilized $\mathrm{Fe}_{3} \mathrm{~S}_{4}$ & Thermal decomposition & $\mathrm{M}_{\mathrm{s}}=37.1 \mathrm{emu} / \mathrm{g}$ & $\mathrm{Pb}(\mathrm{II})$ & $\mathrm{q}_{\mathrm{m}}=256.41 \mathrm{mg} / \mathrm{g}$ & [174] \\
\hline $\mathrm{Fe}_{3} \mathrm{~S}_{4}$-reduced graphene oxide & $\begin{array}{l}\text { Thermal decomposition } \\
\text { and sulfuration }\end{array}$ & $\mathrm{M}_{\mathrm{S}}=20.67 \mathrm{emu} / \mathrm{g}$ & $\mathrm{Pb}(\mathrm{II})$ & $\mathrm{q}_{\mathrm{m}}=285.71 \mathrm{mg} / \mathrm{g}$ & [49] \\
\hline $\mathrm{Fe} / \mathrm{FeS}$ & Sulfidation & $\mathrm{M}_{\mathrm{s}}=78.0 \mathrm{emu} / \mathrm{g}$ & $\mathrm{Cr}(\mathrm{VI})$ & $\mathrm{q}_{\mathrm{m}}=69.7 \mathrm{mg} / \mathrm{g}$ & {$[175]$} \\
\hline $\mathrm{MgFe}_{2} \mathrm{O}_{4}$ & Sol-gel & $\mathrm{M}_{\mathrm{s}}=9.4 \mathrm{emu} / \mathrm{g}$ & $\begin{array}{l}\text { Indigo } \\
\text { carmine dye }\end{array}$ & $\mathrm{q}_{\mathrm{m}}=46 \mathrm{mg} / \mathrm{g}$ & [176] \\
\hline $\mathrm{CuFe}_{2} \mathrm{O}_{4}$ & Solution combustion & $\mathrm{M}_{\mathrm{s}}=18.1 \mathrm{emu} / \mathrm{g}$ & $\begin{array}{l}\text { Malachite } \\
\text { green }\end{array}$ & $\mathrm{q}_{\mathrm{m}}=22 \mathrm{mg} / \mathrm{g}$ & [177] \\
\hline Bio-synthesized $\mathrm{Fe}_{3} \mathrm{O}_{4}$ & $\begin{array}{l}\text { Simple precipitation } \\
\text { using microalgae extract }\end{array}$ & $\mathrm{M}_{\mathrm{s}}=0.2705 \mathrm{emu} / \mathrm{g}$ & $\begin{array}{l}\text { Crystal violet } \\
\text { Methyl } \\
\text { orange }\end{array}$ & $\begin{array}{l}\mathrm{q}_{\mathrm{m}}=256.41 \mathrm{mg} / \mathrm{g} \\
\mathrm{q}_{\mathrm{m}}=270.27 \mathrm{mg} / \mathrm{g}\end{array}$ & {$[21]$} \\
\hline Bio-synthesized $\mathrm{Fe}_{3} \mathrm{O}_{4}$ & $\begin{array}{l}\text { Simple precipitation } \\
\text { using microalgae extract }\end{array}$ & $\mathrm{M}_{\mathrm{s}}=0.2705 \mathrm{emu} / \mathrm{g}$ & $\begin{array}{l}\text { Methylene } \\
\text { blue }\end{array}$ & $\mathrm{q}_{\mathrm{m}}=312.5 \mathrm{mg} / \mathrm{g}$ & [22] \\
\hline Starch-coated $\mathrm{Fe}_{3} \mathrm{O}_{4}$ & Green co-precipitation & $\mathrm{M}_{\mathrm{s}}=46.8 \mathrm{emu} / \mathrm{g}$ & Optilan blue & $\begin{array}{l}\text { Removal efficiency } \\
=72-89 \%\end{array}$ & [178] \\
\hline S-nZVI & Sulfidation & Not reported & Florfenicol & $\begin{array}{l}\text { Removal efficiency } \\
>98 \%\end{array}$ & {$[179]$} \\
\hline S-nZVI & Sulfidation & Not reported & Diclofenac & $\begin{array}{l}\text { Removal efficiency } \\
>85.9 \%\end{array}$ & [180] \\
\hline \multicolumn{6}{|c|}{ Advanced synthesis of magnetic particles on adsorbents } \\
\hline $\begin{array}{l}\text { Pinewood-derived } \\
\text { biochar- } \mathrm{MnFe}_{2} \mathrm{O}_{4}\end{array}$ & Direct pyrolysis & Not reported & $\mathrm{As}(\mathrm{V})$ & $\mathrm{q}_{\mathrm{m}}=3.44 \mathrm{~g} / \mathrm{kg}$ & [181] \\
\hline $\begin{array}{l}\text { Pinewood-derived } \\
\text { biochar- } \gamma-\mathrm{Fe}_{2} \mathrm{O}_{3}\end{array}$ & Direct pyrolysis & Not reported & $\mathrm{As}(\mathrm{V})$ & $\mathrm{q}_{\mathrm{m}}=428.7 \mathrm{mg} / \mathrm{kg}$ & [182] \\
\hline Sodium alginate-dispersed nZVI & Sulfidation & Not reported & $\mathrm{Cr}(\mathrm{VI})$ & $\begin{array}{l}\text { Removal efficiency } \\
=96.4 \%\end{array}$ & [183] \\
\hline Fe-coated bamboo charcoal & $\begin{array}{l}\text { Impregnation and } \\
\text { microwave heating }\end{array}$ & Not reported & $\mathrm{Pb}(\mathrm{II})$ & $\mathrm{q}_{\mathrm{m}}=200.38 \mathrm{mg} / \mathrm{g}$ & {$[184]$} \\
\hline Bagasse-derived biochar & Co-precipitation & $\begin{array}{l}\mathrm{M}_{\mathrm{s}}=0.49-1.17 \\
\mathrm{emu} / \mathrm{g}\end{array}$ & 17 $\beta$-estradiol & $\mathrm{q}_{\mathrm{m}}=34.06-50.24 \mathrm{mg} / \mathrm{g}$ & [185] \\
\hline $\begin{array}{l}\text { Biotemplate-fabricated } \\
\mathrm{ZnFe}_{2} \mathrm{O}_{4} / \mathrm{MgAl} \mathrm{LDH}\end{array}$ & Thermal decomposition & $\mathrm{M}_{\mathrm{S}}=31.8 \mathrm{emu} / \mathrm{g}$ & Congo red & $\mathrm{qm}_{\mathrm{m}}=294.12 \mathrm{mg} / \mathrm{g}$ & {$[186]$} \\
\hline $\mathrm{Ag}-\mathrm{C}-\mathrm{Fe}_{3} \mathrm{O}_{4}$ & Solution combustion & $\mathrm{M}_{\mathrm{s}}=2.6 \mathrm{emu} / \mathrm{g}$ & $\begin{array}{l}\text { Methylene } \\
\text { blue } \\
\text { Acid orange } 7 \\
\text { Rhodamine } \\
6 \mathrm{G}\end{array}$ & $\begin{array}{l}\mathrm{q}_{\mathrm{m}}=152.62 \mathrm{mg} / \mathrm{g} \\
\mathrm{q}_{\mathrm{m}}=154.57 \mathrm{mg} / \mathrm{g} \\
\mathrm{q}_{\mathrm{m}}=168.68 \mathrm{mg} / \mathrm{g}\end{array}$ & [187] \\
\hline Activated carbon- $\mathrm{Fe}_{3} \mathrm{O}_{4}$ & Solution combustion & $\begin{array}{l}\mathrm{M}_{\mathrm{s}}=4.82-13.5 \\
\mathrm{emu} / \mathrm{g}\end{array}$ & $\begin{array}{l}\text { Acid yellow } \\
42 \\
\text { Acid red } 213 \\
\text { Acid orange } 7\end{array}$ & $\begin{array}{l}\mathrm{q}_{\mathrm{m}}=62.36 \mathrm{mg} / \mathrm{g} \\
\mathrm{q}_{\mathrm{m}}=77.99 \mathrm{mg} / \mathrm{g}\end{array}$ & [188] \\
\hline $\mathrm{C}-\mathrm{Fe}_{3} \mathrm{O}_{4}$ & Solution combustion & $\mathrm{M}_{\mathrm{s}}=2.43 \mathrm{emu} / \mathrm{g}$ & $\begin{array}{l}\text { Acid blue } 129 \\
\text { Methylene } \\
\text { blue } \\
\text { Rhodamine } \\
6 \mathrm{G}\end{array}$ & $\begin{array}{l}\mathrm{q}_{\mathrm{m}}=126.19 \mathrm{mg} / \mathrm{g} \\
\mathrm{q}_{\mathrm{m}}=83.42 \mathrm{mg} / \mathrm{g} \\
\mathrm{q}_{\mathrm{m}}=118.15 \mathrm{mg} / \mathrm{g} \\
\mathrm{q}_{\mathrm{m}}=131.80 \mathrm{mg} / \mathrm{g}\end{array}$ & [189] \\
\hline
\end{tabular}


Table 2. Cont.

\begin{tabular}{|c|c|c|c|c|c|}
\hline Adsorbents & Synthesis Method & Magnetic Properties & Pollutant(s) & $\begin{array}{l}\text { Adsorption or } \\
\text { Removal Performance }\end{array}$ & Reference \\
\hline \multicolumn{6}{|c|}{ Advanced synthesis of adsorbents on magnetic particles } \\
\hline Faujasite-type zeolite-- $\mathrm{Fe}_{3} \mathrm{O}_{4}$ & $\begin{array}{l}\text { Seed-assisted } \\
\text { hydrothermal with seed } \\
\text { crystal } / \mathrm{Fe}_{3} \mathrm{O}_{4} \text { mixture }\end{array}$ & Not reported & $\begin{array}{l}\text { Methylene } \\
\text { blue }\end{array}$ & $\mathrm{q}_{\mathrm{m}}=35.7 \mathrm{mg} / \mathrm{g}$ & [29] \\
\hline Activated carbon- $\mathrm{Fe}_{3} \mathrm{O}_{4}$ & $\begin{array}{l}\text { Carbonization of } \mathrm{Fe}_{3} \mathrm{O}_{4} \\
\text { embedded polymer } \\
\text { precursor }\end{array}$ & Not reported & $\begin{array}{l}\text { Methylene } \\
\text { blue }\end{array}$ & $\mathrm{q}_{\mathrm{m}}=650 \mathrm{mg} / \mathrm{g}$ & {$[34]$} \\
\hline BEA-type zeolite- $\mathrm{Fe}_{3} \mathrm{O}_{4}$ & $\begin{array}{l}\text { Dry-gel conversion of } \\
\mathrm{Fe}_{3} \mathrm{O}_{4} \text { pre-mixed } \\
\text { precursor gel }\end{array}$ & Not reported & $\begin{array}{l}\text { Methylene } \\
\text { blue }\end{array}$ & $\mathrm{q}_{\mathrm{m}}=133 \mathrm{mg} / \mathrm{g}$ & [31] \\
\hline $\begin{array}{l}\text { Zn-based zeolitic Imidazolate } \\
\text { MOF-basil seed mucilage } \\
\text { nanocomposite }\end{array}$ & Ultrasonication & $\mathrm{M}_{\mathrm{s}}=2.22 \mathrm{emu} / \mathrm{g}$ & $\begin{array}{l}\text { Methylene } \\
\text { blue } \\
\text { Eriochrome } \\
\text { black T }\end{array}$ & $\begin{array}{l}\mathrm{q}_{\mathrm{m}}=9.09 \mathrm{mg} / \mathrm{g} \\
\mathrm{q}_{\mathrm{m}}=13.21 \mathrm{mg} / \mathrm{g}\end{array}$ & [190] \\
\hline MOR-type zeolite- $\mathrm{Fe}_{3} \mathrm{O}_{4}$ & $\begin{array}{l}\text { Seed-assisted } \\
\text { hydrothermal with seed } \\
\text { crystal } / \mathrm{Fe}_{3} \mathrm{O}_{4} \text { mixture }\end{array}$ & Not reported & Benzene & $\mathrm{q}_{\mathrm{m}}=6.9 \mathrm{mg} / \mathrm{g}$ & {$[30]$} \\
\hline \multicolumn{6}{|c|}{ Co-synthesis of magnetic particles and adsorbents } \\
\hline $\mathrm{ZrO}_{2}-\mathrm{Fe}_{3} \mathrm{O}_{4}$ & Co-precipitation & $\mathrm{M}_{\mathrm{s}}>23.65 \mathrm{emu} / \mathrm{g}$ & Phosphate & $\mathrm{q}_{\mathrm{m}}=27.93-69.44 \mathrm{mg} / \mathrm{g}$ & {$[26]$} \\
\hline $\mathrm{Ma} / \mathrm{Al} / \mathrm{La}-\mathrm{Fe}_{3} \mathrm{O}_{4}$ & $\begin{array}{l}\text { Co-precipitation and } \\
\text { calcination }\end{array}$ & Not reported & $\mathrm{F}_{-}$ & $\mathrm{q}_{\mathrm{m}}=65.75 \mathrm{mg} / \mathrm{g}$ & [191] \\
\hline $\begin{array}{l}\text { Triethylene tetramine } \\
\text { functionalized chitosan } \\
\text { resin- } \mathrm{Fe}_{3} \mathrm{O}_{4}\end{array}$ & $\begin{array}{l}\text { Precipitation and } \\
\text { crosslinking }\end{array}$ & $\mathrm{M}_{\mathrm{s}}=30 \mathrm{emu} / \mathrm{g}$ & Uranyl & $\mathrm{q}_{\mathrm{m}}=166.6 \mathrm{mg} / \mathrm{g}$ & [192] \\
\hline $\mathrm{MgAl} \mathrm{LDH}$ on carbon- $-\mathrm{Fe}_{3} \mathrm{O}_{4}$ & $\begin{array}{l}\text { Hydrothermal } \\
\text { self-assembly and Sol-gel }\end{array}$ & $\mathrm{M}_{\mathrm{s}}=5.84 \mathrm{emu} / \mathrm{g}$ & $\mathrm{Cr}(\mathrm{VI})$ & $\mathrm{q}_{\mathrm{m}}=152.0 \mathrm{mg} / \mathrm{g}$ & [193] \\
\hline $\begin{array}{l}\text { Rice husk-derived carbonaceous } \\
\text { material- } \mathrm{Fe}_{3} \mathrm{O}_{4}\end{array}$ & Carbon-thermal & $\mathrm{M}_{\mathrm{s}}=77.8 \mathrm{emu} / \mathrm{g}$ & $\mathrm{Cr}(\mathrm{VI})$ & $\mathrm{q}_{\mathrm{m}}=157.7 \mathrm{mg} / \mathrm{g}$ & [194] \\
\hline Sludge biochar- $-\mathrm{Fe}_{3} \mathrm{O}_{4}$ & Hydrothermal & $\mathrm{M}_{\mathrm{s}}=29.94 \mathrm{emu} / \mathrm{g}$ & $\mathrm{Pb}(\mathrm{II})$ & $\mathrm{q}_{\mathrm{m}}=174.216 \mathrm{mg} / \mathrm{g}$ & {$[195]$} \\
\hline Biochar- $\mathrm{Fe}_{3} \mathrm{O}_{4}$ & $\begin{array}{l}\text { Electromagnetization and } \\
\text { pyrolysis }\end{array}$ & $\mathrm{M}_{\mathrm{S}}=26.79 \mathrm{emu} / \mathrm{g}$ & Acid orange 7 & $\mathrm{q}_{\mathrm{m}}=382.01 \mathrm{mg} / \mathrm{g}$ & {$[33]$} \\
\hline Fullerene- $-\mathrm{Fe}_{3} \mathrm{O}_{4}$ & $\begin{array}{l}\text { Solvent-free catalytic } \\
\text { thermal decomposition }\end{array}$ & $\mathrm{M}_{\mathrm{s}}=7.002 \mathrm{emu} / \mathrm{g}$ & $\begin{array}{l}\text { Acid blue } 25 \\
\text { Methylene } \\
\text { blue }\end{array}$ & $\begin{array}{l}\mathrm{q}_{\mathrm{m}}=806.5 \mathrm{mg} / \mathrm{g} \\
\mathrm{q}_{\mathrm{m}}=833.3 \mathrm{mg} / \mathrm{g}\end{array}$ & {$[196]$} \\
\hline Polyvinylpyrrolidone-- $\mathrm{Fe}_{3} \mathrm{O}_{4}$ & Modified hydrothermal & Not reported & Crude oil & $\begin{array}{l}\text { Removal efficiency } \\
\approx 100 \%\end{array}$ & [197] \\
\hline
\end{tabular}

$\mathrm{M}_{\mathrm{s}}$ : saturation magnetization; $\mathrm{q}_{\mathrm{m}}$ : maximum adsorption capacity; LDH: layered double hydroxide; MOF: metal organic framework; S-nZVI: sulfidized nano zerovalent iron.

\subsection{Advancements of Magnetic Material Adsorbents}

Recently, the development of more effective adsorbents, based on magnetic materials, has attracted much attention. In this section, we focus on the advancements in the synthesis methods for magnetic material adsorbents. A summary of the recent advancements in the synthesis of magnetic adsorbents has been shown in Table 2 .

\subsubsection{S-nZVI}

Although nZVI technology, from laboratory synthesis to environmental application, has made progress through a comprehensive amount of research, there are still two main technical obstacles to overcome, outlined here: (i) Unstable nZVI often has high surface energy and intrinsic magnetic interactions, meaning that when coupled with the van der Waals force between the particles, nZVI is easier to aggregate. The aggregated nZVI may not be as active as expected. (ii) The reducing property of nZVI may be consumed by non-target pollutants, which leads to a decrease in selectivity [198]. In the research to solve these two problems with nZVI, the sulfidation of nZVI (S-nZVI), a method of chemical modification of nZVI particles by adding sulfur compounds, recently showed that the technology is simple, inexpensive, and environmentally acceptable.

The common precipitation synthesis method of S-nZVI can be roughly divided into the following two categories: the one-step synthesis method and the two-step synthesis 
method. Sodium dithionite $\left(\mathrm{Na}_{2} \mathrm{~S}_{2} \mathrm{O}_{4}\right)$ is the most commonly used sulfidation reagent for one-step synthesis of n-ZVI, where iron salts are precipitated with $\mathrm{NaBH}_{4}$ and $\mathrm{Na}_{2} \mathrm{~S}_{2} \mathrm{O}_{4}$, in one aqueous solution. Results have shown that core-shell structure nanoparticles are formed during the one-step method process, with a wide [S/Fe] dose range (0.07-0.4) [199]. The mixed shell structure is mainly composed of nonuniformly distributed iron hydroxides and iron sulfides $\left(\mathrm{Fe}_{\mathrm{x}} \mathrm{S}_{\mathrm{y}}\right)$. Some studies have also reported the effect of sulfidation on the aggregation of nZVI and the resultant several-fold greater sequestration performance, compared with bare nZVI [142,143]. Song et al. used dithionite as a sulfur source to control the S/Fe molar ratio of S-nZVI. Their XANES results showed that the sulfidation process can effectively inhibit the formation of $\mathrm{FeOOH}$ on the nZVI surface and promote the crystallization of the Fe core. FeS formed on the surface can not only activate oxygen molecules into reactive oxygen species (ROS), improving the reactivity, but also suppress aggregation, due to the increased electrostatic and steric repulsion and the decreased magnetic attraction [180].

Two-step synthesis is conducted by depositing sulfur species on the surface of presynthesized nZVI with $\mathrm{Na}_{2} \mathrm{~S}$ (or other sulfur-containing reagents). Unlike the one-step method that produces rough and irregular particles, the two-step method can generate nanoparticles with similar core-shell morphology and smaller sizes. Smooth spheres are usually arranged in a typical chain-like shape, with needles and plates around the core. Mangayayam et al. [200] reported that the surface layer of S-nZVI synthesized by two steps is about $5 \mathrm{~nm}$ thick, and the surface has defects and heterogeneous crystal orientations. In addition, post-sulfidation, using dithionite, can greatly improve the selectivity of CMC-nZVI on trichloroethylene and eliminate the reaction with water [201]. At the same time, compared to using nZVI alone, S-nZVI usually maintains a longer reaction lifespan. Dithionite dissociates to form sulfur dioxide free radicals and produces sulfite and thiosulfate, which can be used as a scavenger for electron-accepting compounds (such as $\mathrm{O}_{2}$ ) in an aqueous solution, thereby maintaining the zerovalent state of nZVI for a longer period of time [202].

\subsubsection{Ferrite $\left(\mathrm{Mfe}_{2} \mathrm{O}_{4}\right)$}

In recent years, spinel ferrite has become an important magnetic nanoparticle for water treatment. The general formula of ferrite is $\mathrm{Mfe}_{2} \mathrm{O}_{4}$, where $\mathrm{M}$ could be $\mathrm{Zn}, \mathrm{Mg}, \mathrm{Co}, \mathrm{Ni}$, etc. Depending on the position of $\mathrm{M}$ (II) and Fe(III) in the crystallographic sites, there are three different types of ferrite, as follows: normal, inverse, and mixed [203]. It is also easy to separate ferrites from wastewater using an external magnetic field.

"Bottom-up" synthesis methods, including sol-gel, hydrothermal, co-precipitation, and solvothermal, have been the most frequently used methods in recent years. The adsorbent morphology, especially the capacity, is greatly affected by the different raw materials and techniques used. For example, Adel et al. [176] obtained $\mathrm{MgFe}_{2} \mathrm{O}_{4}$, with both microporous and mesoporous structures, by a simple sol-gel method, followed by calcination at $500{ }^{\circ} \mathrm{C}$. Its adsorption capacity for indigo carmine dye reached $46 \mathrm{mg} / \mathrm{g}$ with spherical particles. For another magnesium-zinc ferrite composite, the increase in zinc content improved the removal efficiency of both $\mathrm{Cr}(\mathrm{VI})$ and $\mathrm{Ni}(\mathrm{II})$. The auto-combustion method enhanced the porous structure of the adsorbent [204]. In a study comparing different green synthesis methods, samples obtained by co-precipitation had better removal performance than combustion and microwave-assisted methods [63].

$\mathrm{Fe}_{3} \mathrm{O}_{4}$ is one of the most common ferrites and the mechanism study for the formation of $\mathrm{Fe}_{3} \mathrm{O}_{4}$ has been widely studied. The reaction temperature and solvent mass ratio are two factors that have a significant effect on the production of $\mathrm{Fe}_{3} \mathrm{O}_{4}$, not only for the adsorbent morphology but also the nanoparticle magnetism [205]. Firstly, the size of $\mathrm{Fe}_{3} \mathrm{O}_{4}$ particles will increase, with the increase in reaction temperatures, which has been confirmed by TEM images and calculated by the Debye-Scherrer equation, using XRD data [206]. It is believed that magnetic nanoparticles exhibit a size effect or a high surface area to volume ratio, which results in a higher metal removal adsorption capacity [207]. Secondly, the solvent 
used in the synthesis process is sometimes used as a multitask agent, to help produce precursors, decorate the particles or change the aggregation state of the target product. For example, in order to obtain the monodisperse nanoparticles, $\mathrm{Xu}$ et al. reported a simplified method of monodisperse $\mathrm{Fe}_{3} \mathrm{O}_{4}$, through the decomposition of iron acetylacetonate in benzyl ether and oleylamine [208]. The size of $\mathrm{Fe}_{3} \mathrm{O}_{4}$ can be controlled from 14 to $100 \mathrm{~nm}$, by varying the heating conditions and ratios of oleylamine and oleic acid. The experiment also proved that excessive oleylamine can provide a sufficient reducing environment for the Fe precursor and promote the formation of $\mathrm{Fe}_{3} \mathrm{O}_{4}$ nanoparticles, at a relatively low temperature. In another study, Mohapatra et al. confirmed that the oxidation state of Fe in the prepared nanoparticles affects the superparamagnetic or nonmagnetic state, so as to influence the purity of the $\mathrm{Fe}_{3} \mathrm{O}_{4}$ phase [209]. Thus, both reaction temperature and solvent mass ratios are key factors for magnetite's properties.

\subsubsection{Surfactant Modification}

The functional modification of the surface is a common method of preventing the agglomeration of magnetic nanoparticles. Due to the steric hindrance or electrostatic repulsion, the influence from magnetic forces and van der Waals forces can be effectively suppressed. According to the surface characteristics and application scenarios, surfactantfunctionalized magnetic nanocomposites can be easily classified into oil-soluble, watersoluble, and amphiphilic [210]. Chin et al. has reported a controllable method to obtain magnetite nanoparticles, using environmentally benign and non-toxic polyethylene oxide (PEO) as the solvent and surfactant simultaneously [211]. His study confirmed that the spherical-shaped $\mathrm{Fe}_{3} \mathrm{O}_{4}$ particles were more easily obtained when carboxylic acid (-COOH) existed during the iron acetylacetonate hydrolysis. As a common cationic surfactant, cetyltrimethylammonium bromide (CTAB) has a long, apolar chain that was used to modify palygorskite- $\mathrm{Fe}_{3} \mathrm{O}_{4}$. The treated palygorskite- $-\mathrm{Fe}_{3} \mathrm{O}_{4}$ was positively charged and changed from partially hydrophobic to hydrophilic, which was favorable for the removal of anionic dyes [212]. In contrast, anionic surfactants, such as sodium dodecyl sulfate (SDS), has exhibited the hydrophobic effect and good electrostatic attraction to metal cations, such as $\mathrm{Ni}(\mathrm{II}), \mathrm{Cu}(\mathrm{II}), \mathrm{Zn}(\mathrm{II})$, and other contaminants, including norfloxacin $[213,214]$. Nonionic surfactants, including silica, carbon, and precious metal, can be formed as the coatings or outer shells [215-217]. Cendrowski et al. compared the magnetites coated with solid silica, mesoporous shell, and pristine nanoparticles. The results showed great differences in thermal and chemical stability. Due to the lack of diffusion of oxygen and hydrochloric acid through the silica structure, the thermal stability and acid resistance were both enhanced [218]. For an amphoteric surfactant, $\mathrm{Al}_{2} \mathrm{O}_{3}$ is an example that can react both as an acid and a base. In a study of fluoride adsorption, Chai et al. found that sulfate-doped $\mathrm{Fe}_{3} \mathrm{O}_{4} / \mathrm{Al}_{2} \mathrm{O}_{3}$ exhibited a high capacity, over a wide $\mathrm{pH}$ range. In acidic solutions, the equilibrium $\mathrm{pH}$ is much higher than the initial $\mathrm{pH}$; in alkaline conditions it will drop to a lower value [219]. It has shown a good amphoteric property, which is favorable to the application of adsorbents in natural water environments.

\subsubsection{Green Synthesis}

In recent years, a number of magnetic nanoparticle synthesis methods have been developed. The particle size of nanoparticles can be controlled by great thermal decomposition of the toxic and expensive precursors and surfactant organic solvents. The high thermal energy consumption and large amount of organic waste solvents present significant environmental challenges. Thus, more solvent-less or solvent-free green synthesis methods are being investigated.

Some natural biomass has abundant functional groups and can promote the formation of magnetic particles. Coconut husks have been reported to contain phenolic substances with carboxyl groups on the surface, such as benzoic acid and caffeic acid, which could stabilize the magnetite dispersions, over a wide $\mathrm{pH}$ range [220]. In a similar study, iron oxide nanoparticles were mixed with tangerine peel extract. When the $\mathrm{pH}$ value was 4 
and the adsorbent dosage was $4 \mathrm{~g} / 100 \mathrm{~mL}$, the maximum removal rate of $\mathrm{Cd}(\mathrm{II})$ ions was 90\% [221]. The magnetic material modified by starch also has a good crystal form and maintains a good removal effect on textile dyes, other than heavy metals [178]. However, a pre-synthesized magnetic nanoparticle and aqueous solution are required to obtain the nanocomposite.

Using waste ferrous sulfate as the main iron source, magnetite $\left(\mathrm{FeFe}_{2} \mathrm{O}_{4}\right)$ nanoparticles were synthesized through solvent-free reduction reactions [222]. At room temperature, the porous magnetite nanoparticles have an $\mathrm{M}_{\mathrm{s}}$ of approximately $77 \mathrm{emu} / \mathrm{g}$, which is sufficient for separation from wastewater, using an external magnetic field. Using industrial waste as a raw material to synthesize porous magnetite nanoparticles not only reduces production costs but also ensures clean production and eases environmental pressure. Sulfur dioxide produced in the reduction reaction is recycled with water to produce sulfuric acid [222]. In addition, magnetic carbonaceous adsorbents produced by ball milling biochar or activated carbon and $\mathrm{Fe}_{3} \mathrm{O}_{4}$ nanoparticles were obtained using a solvent-free method, and their ability to adsorb methylene blue from water was evaluated and compared [223] (Figure 8a). A possible multiple adsorption mechanism includes electrostatic interaction bonding, ion exchange, and $\pi$ electronic interaction, resulting in a maximum capacity of $500.5 \mathrm{mg} / \mathrm{g}$. Although green synthesis has many advantages, the removal efficiency and the solvent-free reaction mechanism need to be improved.

(a)

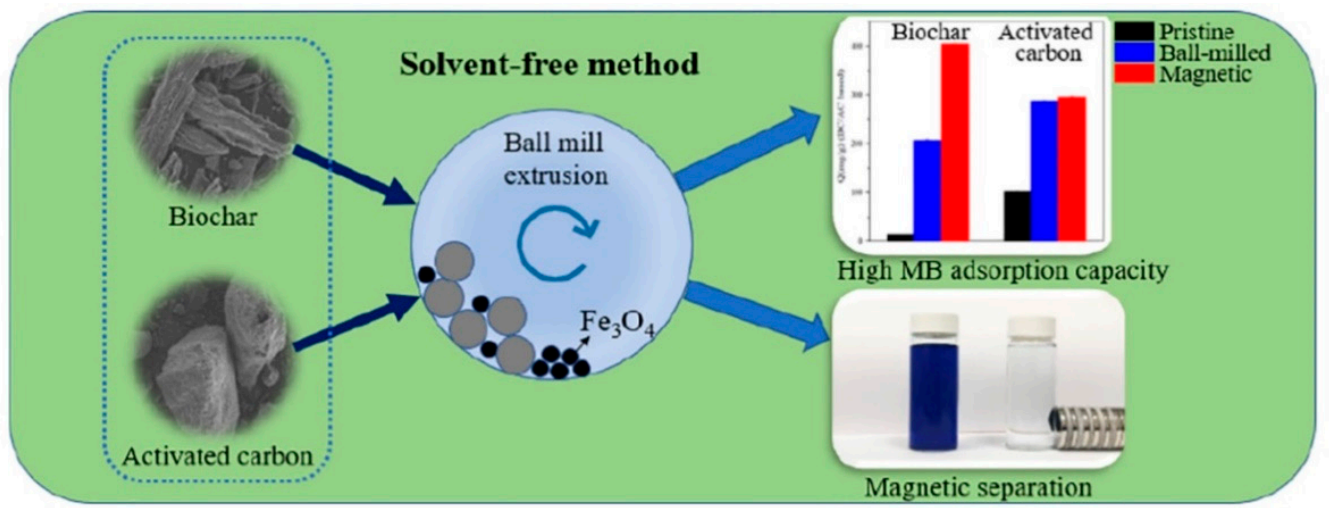

(b)

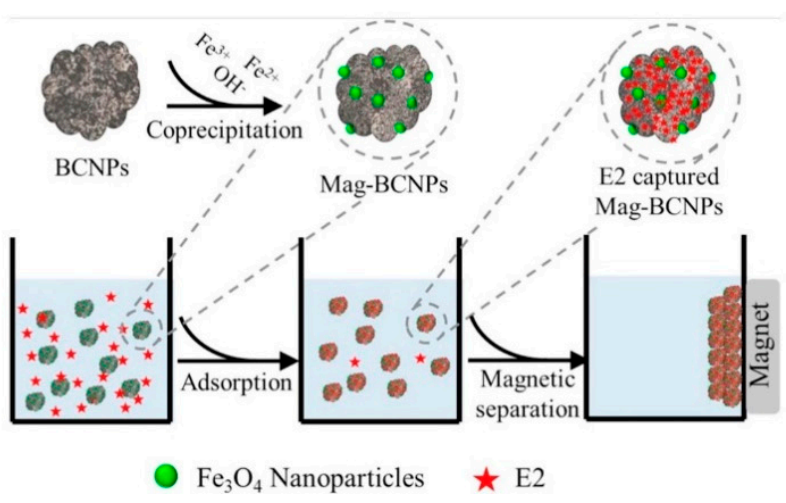

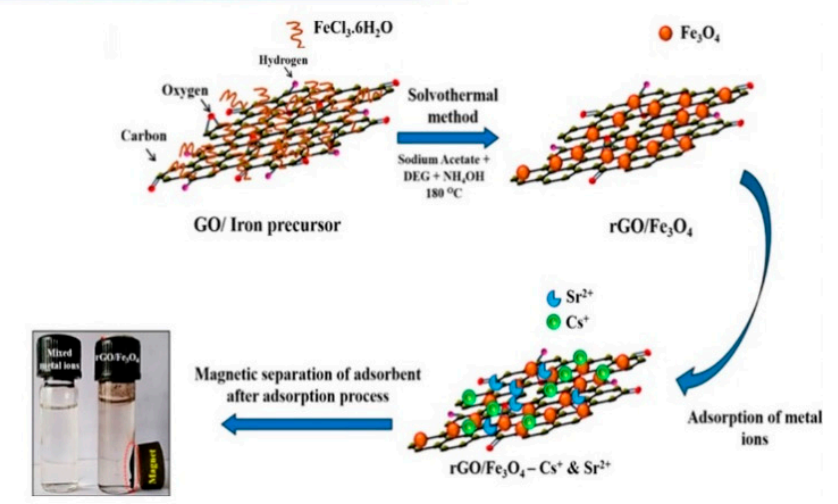

GO/ Iron precursor

Figure 8. Preparation procedures of $\mathrm{Fe}_{3} \mathrm{O}_{4}$ loaded on (a) magnetic biochar and activated carbon, (b) nanosized biochar particles and (c) RGO. (Reprinted from (a) Sci. Total Environ. 722, Li, Y.; Zimmerman, A.R.; He F.; Chen, J.; Han, L.; Chen, H.; Hu, X.; Gao, B. Solvent-free synthesis of magnetic biochar and activated carbon through ball-mill extrusion with $\mathrm{Fe}_{3} \mathrm{O}_{4}$ nanoparticles for enhancing adsorption of methylene blue. 137972. Ref. [223], Copyright (c 2022 and (b) Chem. Eng. J. 352, Dong, X.; He, L.; Hu, H.; Liu, N.; Gao, S.; Piao, Y. Removal of $17 \beta$-estradiol by using highly adsorptive magnetic bio-char nanoparticles from aqueous solution. 371-379. Ref. [185], Copyright $@$ 2022 with permission from Elsevier and (c) Ind. Eng. Chem. Res. 2018, 57, 4, 1225-1232 Ref. [224] Copyright (c) 2022 American Chemical Society). 
Recently, solution combustion synthesis (SCS) has become a widely adopted technique for fabricating nanomaterials, especially nano oxides, due to its attractive advantages of being simple, non-polluting, energy saving, and highly efficient. Typically, metal hydrazinecarboxylate hydrates are solid at room temperature and have a complex crystal structure. They will produce ultrafine solid oxides of corresponding metals and a large quantity of gaseous products, at relatively low temperatures $\left(125-250{ }^{\circ} \mathrm{C}\right)$. Due to their exothermic and self-sustained properties, the reaction can be carried out until complete conversion, without any additional external energy input. Therefore, it is an energy-saving and sustainable synthesis method [225,226]. Xuanli Wang et al. developed a one-step SCS method to prepare $\mathrm{Fe}_{3} \mathrm{O}_{4}$ nanoparticles and the obtained samples have a high saturation magnetization of $89.17 \mathrm{emu} / \mathrm{g}$ and a small grain size of $57.3 \mathrm{~nm}$. The flame temperature and the quantity of gaseous products released, depend on the nature of the fuel and the ratio of fuel to oxidant $(\varphi)$. As the molar ratio of glycine (fuel) increases, the combustion mode changes from self-propagating combustion to smoldering combustion, and the oxide phase of SCS products sequentially changes from $\alpha-\mathrm{Fe}_{2} \mathrm{O}_{3} \rightarrow \mathrm{Fe}_{3} \mathrm{O}_{4} \rightarrow \mathrm{FeO}$ [227]. The mechanisms for the formation of magnetite were further discussed by Aali et al. [228]. Glycine, urea and citric acid were used as fuels, and an overview of the results revealed that porous single-phase magnetite nano powder, with high crystallinity and saturation magnetization, was only achieved when $\varphi=0.95$; the highest saturation magnetization reached $99 \mathrm{emu} / \mathrm{g}$. Magnetite and hematite were produced simultaneously in the case of urea, while in the case of glycine and citric acid, first magnetite was prepared and then oxidized to hematite. SCS also allows for the effective doping of materials and mixing with other supporting materials, to achieve large-scale production, for a wider range of applications.

\subsection{Advancements in Synthesis of Magnetic Particles on Adsorbents}

The synthesis of adsorbents with magnetic particles and high adsorption performance through conventional synthesis methods is still challenging. Therefore, an effective and green synthesis process should be developed. To maximize the efficiency of magnetic particles on adsorbents, methods that facilitate the formation of particles with uniform size, monodispersity, and non-aggregation can be applied.

\subsubsection{Uniform Distribution of Nanoparticles}

The diffusion, transfer, fate, and environmental risks of engineered nanoparticles (ENPs) dispersed in liquid are significantly different from those of aggregation. Zhang et al. [229] showed that when the concentration of ENPs is lower than the critical micelle concentration (CMC), steric hindrance and/or electrostatic repulsion play a major role in their dispersion. When the dispersant is higher than its CMC, the dispersion of ENPs can be regarded as the "dissolution" process of the dispersant in the micelles. To overcome these agglomeration problems, associated with nanometer size, nanoparticles with high dispersion and high thermodynamic stability have been investigated.

In a recent study, sodium alginate was used to disperse nZVI to develop a new type of nZVI material [183]. Polymers chelate and coordinate ferrous ions before in situ redox, which results in an artificial "concentration" of iron into the polymer area; thus, aggregation of polymer-modified nanoparticles may be lower in an aqueous solution [230]. In addition, hydroxyl group-containing molecules that have a surface passivation effect can also inhibit subsequent crystallization, by preventing further oxidation bond formation. The increase in the number of hydroxyl groups results in a large surface energy and enhances the stability of the intermediate, consequently restraining the transformation into a crystalline form.

Functionalized, high-salt-tolerant magnetite nanoparticles were synthesized by a onestep synthesis, with sulfonated phenolic resin. Even in high-salt environments, strong anionic sulfonate groups can promote sufficient electrostatic repulsion between particles to separate them [231]. The deprotonated anionic coating can maintain the high negative charge on the surface of nanoparticles and can provide strong electrostatic repulsion, in the 
typical $\mathrm{pH}$ range of the natural aquatic environment, to maintain a highly dispersed state. However, pollutants that also have a negatively charged surface will affect adsorption and cause instability in the colloidal solution. The influence of $\mathrm{pH}$, cations, anions, and humic acid on the aggregation behavior of citric acid-coated magnetite nanoparticles in the aqueous phase has been reported by Liu et al. [232].

\subsubsection{Bio-Derived Magnetic Nanocomposite}

Many conversion schemes have been developed to use the characteristics of biomass feed to prepare adsorbents. Both biological (anaerobic digestion, hydrolysis, and fermentation) and thermal (combustion, pyrolysis, liquefaction, baking, and gasification) methods are used to convert biomass into adsorbents. Biochar from heat treatment usually has a high energy density (usually $>28 \mathrm{~kJ} / \mathrm{g}$ ) [233]. Magnetic biochar is mainly prepared by the following three methods: calcination, co-precipitation, and pyrolysis [234]. Generally, the typical pyrolysis process can be subdivided into fast pyrolysis, slow pyrolysis, and flash pyrolysis. Co-precipitation is a bottom-up ion precipitation reaction. Calcination is a heat treatment process in which small molecules, such as $\mathrm{H}_{2} \mathrm{O}, \mathrm{CO}_{2}$, and $\mathrm{SO}_{2}$, are removed [234]. The factors affecting the adsorption of pollutants by the magnetic biochar are summarized below.

There have been attempts to develop a magnetic biochar adsorbent to ensure a better and more effective separation of biochar particles, after the wastewater treatment process [181,233]. Further, several studies have been conducted, wherein biochar is magnetized, characterized, and applied to wastewater treatment [182,184,185,235] (Figure 8). Park et al. [236] used sesame straw raw biochar to adsorb multiple metal ions $(\mathrm{Pb}, \mathrm{Cr}, \mathrm{Cd}, \mathrm{Cu}$, and $\mathrm{Zn}$ ) from wastewater. The results showed that its adsorption behavior for multi-metals was different from single-metal adsorption; in multi-metals, the adsorption of Cd was particularly impeded due to competition. However, to ensure the applicability of magnetic biochar for wastewater treatment, it is necessary to use physical and chemical conditions to simulate polluted water or use actual polluted water.

The high surface area produces rapid adsorption kinetics and, thus, a relatively short contact time. Furthermore, these nanocomposites are magnetic and can be separated from aqueous streams using an external magnetic field. Overall, magnetic nanocomposites have become a revolutionary tool for wastewater treatment, due to their unique properties and the overlap with current technologies.

\subsubsection{Matrice-Confined NPs}

The physical confinement of nanoparticles within the structure is mainly based on weak interactions, generated by hydrogen bonds, $\pi-\pi$ bonds, or covalent grafting, which can be achieved by in situ chemistry or post-processing methods. A physical confinement strategy is attractive as the specific reactivity of the nanoparticles is retained, and the performance can be easily adjusted by changing the size and shape of the pores, to promote the regional growth of the nanocrystals. Among them, porous carbon, mesoporous silicon oxide, aluminum oxide, and montmorillonite have been widely studied.

Silica has many advantages, such as low cost, easy preparation, good liquid dispersion, easy modification, $\mathrm{pH}$ resistance, and thermal stability, making it highly suitable for use in magnetic composites. Generally, the magnetic particles may be arranged on different areas of the mesoporous silicon oxides, for example, as a core, scattered distribution, or fixed/grafted on the surface or in the siliceous framework, by functionalization in the mesopores. For instance, $\mathrm{Fe}_{3} \mathrm{O}_{4}$ nanoparticles coated with silica and naphthoyl chloride $\left(\mathrm{Fe}_{3} \mathrm{O}_{4} @ \mathrm{SiO}_{2} @ \mathrm{Nap}\right)$ [237], porphyrin copolymer $\left(\mathrm{Fe}_{3} \mathrm{O}_{4} @ \mathrm{SiO}_{2}-\mathrm{TCPP}\right)$ [238], lignin $\left(\mathrm{Fe}_{3} \mathrm{O}_{4} @ \mathrm{SiO}_{2}-\mathrm{NH}-\mathrm{MFL}\right)$ [120], and porous aromatic frameworks $\left(\mathrm{Fe}_{3} \mathrm{O}_{4} @ \mathrm{SiO}_{2} @ \mathrm{PAF}-6\right)$ [239] have been applied to water samples, to achieve ultrafast absorption. Improved Stöber and template removal methods are used to prepare magnetic mesoporous silica nanoparticles (MSNs), which contain a $\mathrm{Fe}_{3} \mathrm{O}_{4}$ core and a mesoporous silica shell [240]. 
Compared with one-dimensional materials with lower adsorption capacity, advanced two-dimensional materials have a higher surface area and better adsorption potential. Graphene is a typical two-dimensional material. As a carbon derivative, graphene exhibits high porosity. Graphene-based adsorbents have been widely studied for water treatment applications. In recent studies, magnetic iron sulfide $\left(\mathrm{Fe}_{3} \mathrm{~S}_{4}\right)$ was synthesized via a solvothermal process. The synthesized samples were analyzed, using various characterization techniques, to understand the adsorption mechanism of $\mathrm{Pb}$ (II) [49]. In another study, the authors compared the removal effect of a magnetic composite consisting of one-dimensional nanofibers and two-dimensional graphene, for $\mathrm{Pb}(\mathrm{II})$ and $\mathrm{Cr}(\mathrm{VI})$, respectively. The adsorption capacities of graphene and nanofibers for $\mathrm{Pb}$ (II) ions were 131.40 and $42.90 \mathrm{mg} / \mathrm{g}$, respectively. In the case of $\mathrm{Cr}(\mathrm{VI})$ ions, the adsorption capacities were 68.85 and $51.07 \mathrm{mg} / \mathrm{g}$, respectively [241]. In addition, two-dimensional, ultrathin nanosheetlike LDHs were modified with magnetic particles [242,243]. In this work, the improved adsorption performance was due to the enhanced exposure of active sites to pollutants.

Magnetic materials based on biosorbents are considered to be highly efficient and environmentally friendly. These synergistic biomaterials can be used to modify magnetic nanoparticles with various adsorption mechanisms, for use in simple applications and to achieve reusability [244]. For instance, cholesterol improves the stability of magnetic phosphatidylcholine, by increasing the accumulation of phospholipid molecules, which may improve the reusability of the adsorbent (>8 times) for the extraction of Organochlorine pesticides (OCPs). Cholesterol-functionalized magnetic nanoparticles can be obtained using APTES and cholesteryl chloroformate modification [245]. Verma et al. [246] synthesized magnetic biosorbents from citrus (peel and pulp) biomass waste, for wastewater treatment. Samples were synthesized at $500{ }^{\circ} \mathrm{C}$, and both $\mathrm{As}(\mathrm{III})$ and $\mathrm{As}(\mathrm{V})$ from groundwater were removed. Many new adsorbents are still in the laboratory stage. They have demonstrated the ability to adsorb pollutants from water, under different $\mathrm{pH}$ values, different ionic strengths, and mixed with a large amount of organic matter. The adsorption capacity and removal mechanisms are gradually being understood. In future studies, the main challenges faced by wastewater treatment may result in the inclination to investigate environmental application risk, life cycle, and long-term evolution mechanisms.

\subsection{Advancements in Synthesis of Adsorbents on Magnetic Particles}

Efforts to synthesize well-incorporated magnetic adsorbents with uniform size and good adsorption performance are still challenging. The incorporation of magnetic particles into the adsorbents can be achieved by limiting the adsorbent formation in the vicinity of the magnetic particles. The advanced synthesis of adsorbents on magnetic particles can be accomplished by controlling or directing the growth of the adsorbent on magnetic particles, or by using pre-attached magnetic particles with adsorbent precursors. The synthesis procedures introduced in research articles, representing recent advancements in this category, are briefly depicted in Figure 9. 
(a) Embedding into polymer precursors

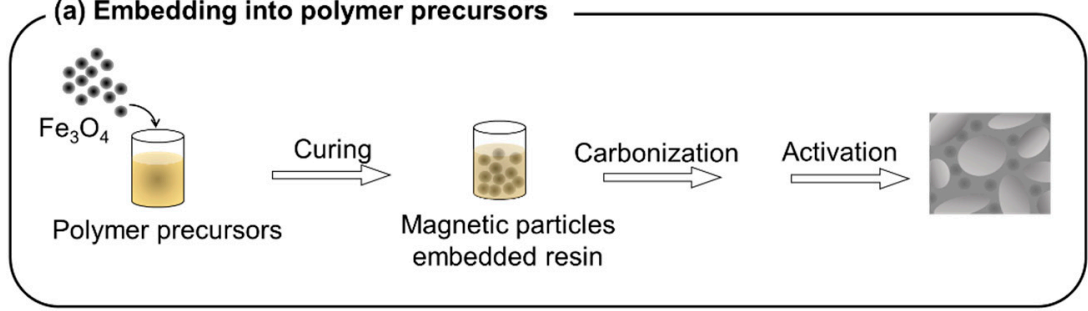

(b) Pre-milling together with seed crystals

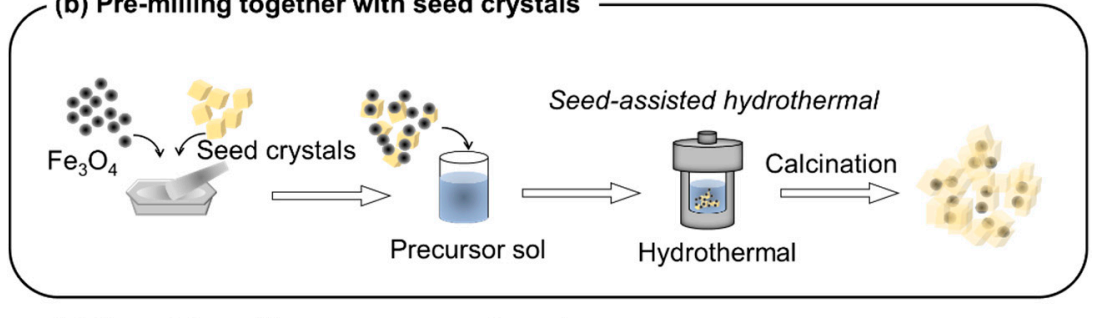

(c) Pre-mixing with precursors as dry gel

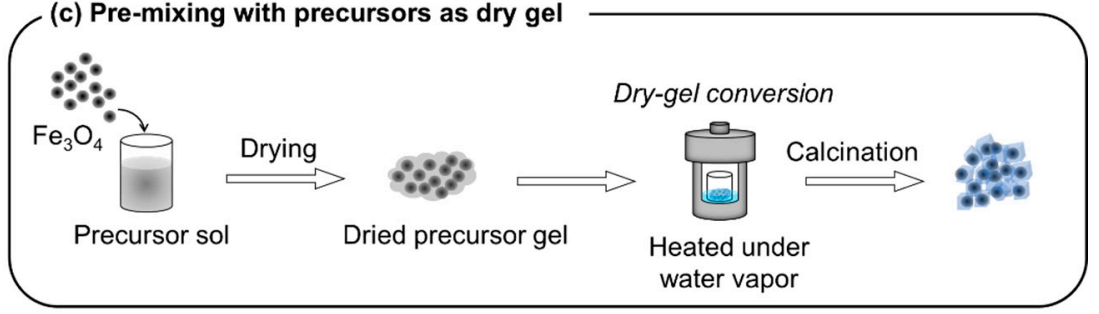

(d) Pre-attaching with precursors using gelatinous material

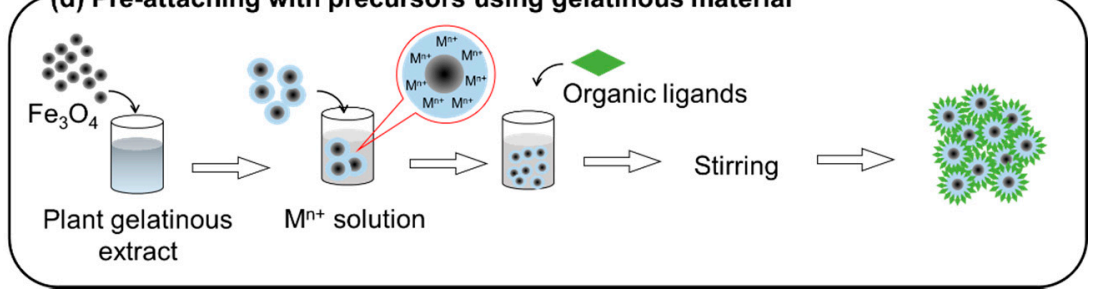

Figure 9. Brief procedures of the advanced synthesis of adsorbents on magnetic particles. (a) Embedding $\mathrm{Fe}_{3} \mathrm{O}_{4}$ into polymer precursors to yield magnetic activated carbon. (b) Pre-milling of $\mathrm{Fe}_{3} \mathrm{O}_{4}$ with zeolite seed crystals together to produce magnetic zeolites. (c) Pre-mixing $\mathrm{Fe}_{3} \mathrm{O}_{4}$ with zeolite precursors to form dried precursor gel before dry gel conversion to magnetic zeolite. (d) Pre-attaching gelatinous material coated $\mathrm{Fe}_{3} \mathrm{O}_{4}$ with metal ion precursor with subsequent formation of MOFs.

\subsubsection{Embedding into Polymer Precursors}

The rigid nature of natural carbon sources limits their ability to combine with magnetic particles. Nijpanich et al. [34] produced the first study to successfully incorporate magnetic particles into small-sized activated carbon, by embedding $\mathrm{Fe}_{3} \mathrm{O}_{4}$ particles into epoxy resin as a carbon source. The starting materials of the epoxy resin were mixed with $\mathrm{Fe}_{3} \mathrm{O}_{4}$ particles, before curing at room temperature (Figure 9a). This process allowed the incorporation of magnetic particles into the carbon source, prior to the carbonization and activation process. The as-prepared magnetic-activated carbon showed no significant difference in methylene blue adsorption performance, compared to non-magnetic-activated carbon prepared by the same route. The performance, however, was higher than that of magnetic-activated carbon derived from other carbon sources. There was no negative effect due to the embedded magnetic particles on the porosity and adsorption performance of the activated carbon. Although the Fe phase was found in the final product by XRD analysis due to the reduction of $\mathrm{Fe}_{3} \mathrm{O}_{4}$ under the activation conditions, the adsorbents were more easily collected using an external magnet, owing to a higher magnetic susceptibility. 


\subsubsection{Application of Seed Crystals}

Recent studies have shown advancements in the synthesis of magnetic zeolites. Hagio et al. applied seed-assisted hydrothermal synthesis, an alternative but selective technique for preparing zeolites, to synthesize magnetic FAU-type [29] and MOR-type zeolites [30] for the first time (Figure 9b). In principle, with hydrothermal treatment, the addition of the target zeolite crystals as the seed into precursors can induce and accelerate the crystallization of zeolites. Therefore, a high product yield was obtained. Seed crystals act as nucleation centers for crystal growth. According to this principle, if the seed crystals are well mixed with magnetic particles, the target zeolites crystallize near the magnetic particles. Hagio et al. discovered that pre-milling seed crystals and $\mathrm{Fe}_{3} \mathrm{O}_{4}$ particles together, before adding to the precursors, allowed for good pre-attachment among them [30]. The growth of zeolite crystals occurred in the tiny gaps between the seed and $\mathrm{Fe}_{3} \mathrm{O}_{4}$ particles. Consequently, the $\mathrm{Fe}_{3} \mathrm{O}_{4}$ particles were completely incorporated inside the zeolite crystals. Furthermore, the amount of magnetic zeolite produced by the seed-assisted technique was found to be almost two times higher than that prepared without seed crystals. Both magnetic FAU-type and MOR-type zeolites showed good separability from solutions, using an external magnet. The magnetic FAU-type zeolite showed similar performance of methylene blue adsorption to the non-magnetic one, which revealed no adverse effects from the incorporated $\mathrm{Fe}_{3} \mathrm{O}_{4}$, inside the FAU frameworks.

\subsubsection{Pre-Mixing into Precursor Gel}

Another advancement of magnetic zeolite synthesis is the utilization of the dry-gel conversion (DGC) method, first presented by Phouthavong et al. [31]. Some researchers have already introduced this technique, which crystallizes a precursor gel under heated vapor to synthesize well-crystallized non-magnetic zeolites [247,248]. In this route, $\mathrm{Fe}_{3} \mathrm{O}_{4}$ particles were homogenously pre-mixed into dry gel precursors before placing under heat water vapor (Figure 9c). Because the $\mathrm{Fe}_{3} \mathrm{O}_{4}$ particles were closely attached to the precursors in the dry gel, they were subsequently incorporated into the BEA-type zeolite during crystal growth. After the DGC, the obtained particles were collected without washing and subsequently calcinated to remove the organic template. Low waste generation is another advantage of DGC. The obtained magnetic BEA-type zeolite had a homogenous and uniform shape, size, and magnetic response. Their adsorption ability to remove methylene blue from water was similar to that of non-magnetic BEA. This indicates that the incorporated $\mathrm{Fe}_{3} \mathrm{O}_{4}$ particles did not clog the pores of the zeolite.

\subsubsection{Pre-Attaching with Precursor Using Gelatinous Material}

Recently, basil seed mucilage, a plant-based product, was also used in magnetic composite synthesis technology. Mahmoodi and Javanbakht [190] prepared magnetic MOF nano-biocomposites by depositing gelatinous parts, extracted from basil seed mucilage, on $\mathrm{Fe}_{3} \mathrm{O}_{4}$ particles and further modifying them with ZIF-8 MOFs. To synthesize ZIF-8, a $\mathrm{Zn}$ (II)-methanol solution was stirred in the presence of mucilage-coated $\mathrm{Fe}_{3} \mathrm{O}_{4}$ particles. The $\mathrm{Zn}$ (II) ions were absorbed into the mucilage via electrostatic interactions (Figure 9d). Therefore, the $\mathrm{Zn}$ (II)-loaded, mucilage-coated $\mathrm{Fe}_{3} \mathrm{O}_{4}$ particles acted as nucleation centers for the growth of ZIF-8, after the addition of the organic precursor, 2-methylimidazole.

\subsection{Co-Synthesis of Magnetic Particles and Adsorbents}

In some cases, adsorbents and magnetic materials can be synthesized using a similar process. Methods to simultaneously synthesize adsorbents and magnetic materials have recently been proposed. To the best of our knowledge, this one-pot synthesis method was first introduced in the past decade. The co-synthesis methods are briefly introduced in Figure 10. 
(a) co-synthesis by hydrothermal treatment

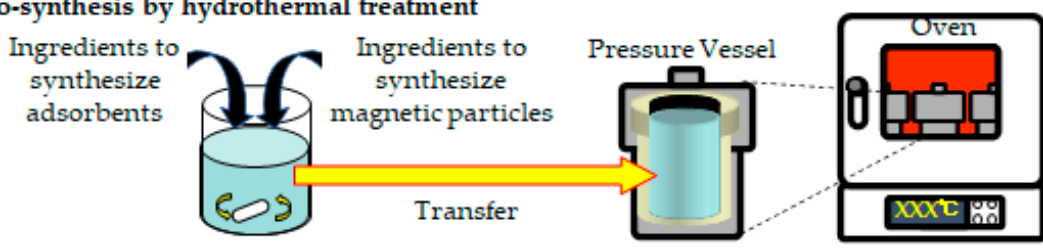

(b) co-synthesis by heat treatment

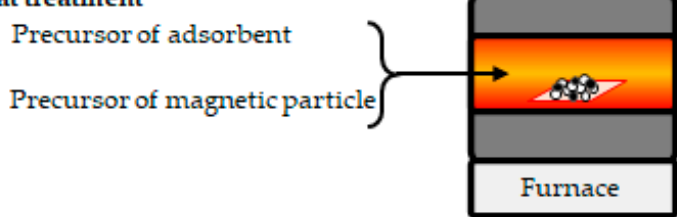

(c) co-synthesis by co-precipitation
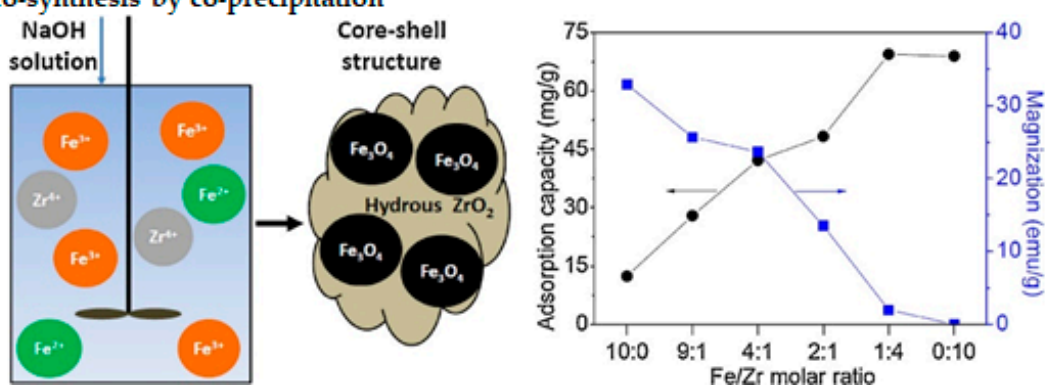

Figure 10. Illustrations of procedures for co-synthesis methods. (a) Hydrothermal, (b) heat treatment, and (c) co-synthesis methods. ((c) Reprinted from Appl. Surf. Sci. 366, Wang, Z.; Xing, M.; Fang, W.; Wu, D. One-step synthesis of magnetite core/zirconia shell nanocomposite for high efficiency removal of phosphate from water, 67-77. Ref. [26], Copyright @ 2022 with permission from Elsevier).

\subsubsection{Co-Synthesis via Hydrothermal Synthesis}

Because $\mathrm{Fe}_{3} \mathrm{O}_{4}$ (magnetic particles) can be synthesized from alkaline solutions containing $\mathrm{Fe}(\mathrm{II})$ and $\mathrm{Fe}(\mathrm{III})$, adsorbents that crystallize from alkaline solutions have been considered for the co-synthesis of adsorbents and magnetic particles. In 2013, Aono et al. [249] prepared a composite material, consisting of Na-P1-type zeolite, and nanosized magnetite, by alkali processing from a mixed solution of fly ash and $\mathrm{FeCl}_{2}$ and $\mathrm{FeCl}_{3}$, followed by hydrothermal synthesis at $100{ }^{\circ} \mathrm{C}$ for $24 \mathrm{~h}$. From TEM observations, $\mathrm{Fe}_{3} \mathrm{O}_{4}$ nanoparticles were observed at the grain boundaries between the polycrystalline zeolites. This was expected, as the formation of zeolite crystals is slower than the formation of nanosized $\mathrm{Fe}_{3} \mathrm{O}_{4}$. The resulting magnetic zeolite could achieve a $61 \%$ decontamination of soil containing radioactive Cs. Chen et al. [195] prepared magnetic $\mathrm{MnFe}_{2} \mathrm{O}_{4}$-sludge biochar via a one-pot hydrothermal synthesis for $\mathrm{Pb}$ (II) removal. Dried sludge obtained from sewage was added to deionized water and mixed with $\mathrm{MnCl}_{2} \cdot 4 \mathrm{H}_{2} \mathrm{O}$ and $\mathrm{FeCl}_{3} \cdot 6 \mathrm{H}_{2} \mathrm{O}$. $\mathrm{NaOH}(5 \mathrm{M})$ was added dropwise, until the $\mathrm{pH}$ reached 10-10.5. This was followed by hydrothermal synthesis at $180^{\circ} \mathrm{C}$ for $10 \mathrm{~h}$. The washed and dried product was tested with a $\mathrm{Pb}$ (II)-containing solution and showed a maximum adsorption amount of $174.216 \mathrm{mg} / \mathrm{g}$.

\subsubsection{Co-Synthesis via Heat Treatment}

Another approach is to embed the iron ions into organic materials, followed by heat treatment in a vacuum or inert gas atmosphere. In this method, the polymeric material turns into active carbon adsorbents, and iron ions crystallize into $\mathrm{Fe}_{3} \mathrm{O}_{4}$ particles. Fan et al. [194] used rice husks, pretreated with a $2 \mathrm{M} \mathrm{NaOH}$ solution, and added them to ethanol, containing $\mathrm{FeCl}_{3} \cdot 6 \mathrm{H}_{2} \mathrm{O}$. After drying, heat treatment at $800{ }^{\circ} \mathrm{C}$ was conducted for $2 \mathrm{~h}$, under a $\mathrm{N}_{2}$ atmosphere. $\mathrm{Fe}_{3} \mathrm{O}_{4}$ particles were deposited on carbonaceous material. Adsorption capacities against $\mathrm{Cr}(\mathrm{VI})$ of this magnetic carbonaceous material in 50 and $100 \mathrm{mg} / \mathrm{L} \mathrm{Cr}(\mathrm{VI})$ solutions were 49.913 and $99.158 \mathrm{mg} / \mathrm{g}$, respectively. The saturated magnetization was $77.8 \mathrm{emu} / \mathrm{g}$. Jung et al. [33] prepared magnetic biochar $/ \mathrm{Fe}_{3} \mathrm{O}_{4}$ nanocomposites, using 
brown marine macroalgae as the precursor for biochar. An electrochemical technique was used to supply the iron ions, and heat treatment was carried out at $600{ }^{\circ} \mathrm{C}$ for $1 \mathrm{~h}$. The magnetic biochar possessed superparamagnetic characteristics, with a saturation magnetization of approximately $26.79 \mathrm{emu} / \mathrm{g}$, and showed a maximum adsorption capacity of $382.01 \mathrm{mg} / \mathrm{g}$ for acid orange 7 , a type of dye, at $30^{\circ} \mathrm{C}$. Although the process is one-pot synthesis, these methods require some pretreatments. Elessawy et al. [196] synthesized functionalized magnetic fullerene nanocomposites in a one-pot process, using cut PET bottle waste and ferrocene. The two materials were introduced into a stainless steel autoclave reactor, which was heated to $800{ }^{\circ} \mathrm{C}$ for $20 \mathrm{~h}$, resulting in a black product. This was a facile, one-step, green synthesis route, using catalytic thermal decomposition of PET bottle waste as a precursor and ferrocene as a catalyst and precursor for magnetic nanoparticles in the composite. The nanocomposite showed saturated magnetization of $7.002 \mathrm{emu} / \mathrm{g}$ and a maximum adsorption of 833.3 and $806.5 \mathrm{mg} / \mathrm{g}$ against methylene blue and acid blue 25, respectively, at $25^{\circ} \mathrm{C}$.

\subsubsection{Co-Synthesis via Co-Precipitation}

Co-precipitation is also extended to realize the one-pot synthesis of magnetic adsorbents. Wang et al. [26] demonstrated the one-step synthesis of $\mathrm{Fe}_{3} \mathrm{O}_{4}$ core/zirconia shell nanocomposites, using the co-precipitation method. Particular amounts of $\mathrm{FeSO}_{4} \cdot 7 \mathrm{H}_{2} \mathrm{O}$, $\mathrm{FeCl}_{3} \cdot 6 \mathrm{H}_{2} \mathrm{O}$, and $\mathrm{ZrOCl}_{2} \cdot 8 \mathrm{H}_{2} \mathrm{O}$ were dissolved in doubly distilled water. Precipitation was caused by the dropwise addition of a $6 \mathrm{M} \mathrm{NaOH}$ solution, under stirring at $400 \mathrm{rpm}$, until the $\mathrm{pH}$ reached 7.6, and was aged without stirring at $60^{\circ} \mathrm{C}$ for $18 \mathrm{~h}$. The washed, collected, and dried product consisted of ball-like or hexagonal particles of $\mathrm{Fe}_{3} \mathrm{O}_{4}$ and cloud-like zirconia. The adsorption performance was evaluated through phosphate removal, which exhibited maximum adsorption capacities of $27.93-69.44 \mathrm{mg} / \mathrm{g}$, when the $\mathrm{Fe} / \mathrm{Zr}$ molar ratio was varied between 9:1 to 1:4, as shown in Figure 10c.

Zhao et al. [191] synthesized a magnetic Mg-Al-La composite using co-precipitation, followed by calcination for fluoride removal. Similar to the aforementioned study, a solution containing $\mathrm{FeSO}_{4} \cdot 7 \mathrm{H}_{2} \mathrm{O}$ and $\mathrm{FeCl}_{3} \cdot 6 \mathrm{H}_{2} \mathrm{O}$ was mixed with another solution containing $\mathrm{Mg}\left(\mathrm{NO}_{3}\right)_{2} \cdot 6 \mathrm{H}_{2} \mathrm{O}, \mathrm{Al}\left(\mathrm{NO}_{3}\right)_{3} \cdot 9 \mathrm{H}_{2} \mathrm{O}$, and $\mathrm{La}\left(\mathrm{NO}_{3}\right)_{3} \cdot 6 \mathrm{H}_{2} \mathrm{O}$, and then a $\mathrm{NaOH}$ solution was added dropwise to carry out co-precipitation. The $\mathrm{Mg}-\mathrm{Al}-\mathrm{La}$ hydroxide material exhibited a hydrotalcite-like structure, and iron was converted to $\mathrm{Fe}_{3} \mathrm{O}_{4}$ by calcination. The calcined magnetic Mg-Al-La composite showed a maximum adsorption capacity of $65.75 \mathrm{mg} / \mathrm{g}$ against fluoride.

Although the co-synthesis of adsorbents and magnetic particles is rather simple, it should be noted that it does not solve all the difficulties in the preparation of magnetic adsorbents, such as the prevention of adsorption sites by magnetic particles. Control of the structure during the synthesis and the combination of appropriate adsorbents and magnetic materials may overcome these issues.

\section{Summary and Future View}

In conclusion, the advancement in the synthesis methods of magnetic adsorbents, for the removal of substances from water streams, has been comprehensively summarized and discussed. Although numerous techniques have been developed for the preparation of magnetic adsorbents with effective adsorption performance, reviews that focus on the synthesis methods of magnetic adsorbents for wastewater treatment and the obtained material structures have not been reported, which are important for the future development of such materials. Generally, the typical synthesis methods are categorized into the following five groups: direct use of magnetic particles, attachment of pre-prepared adsorbents and pre-prepared magnetic particles, synthesis of magnetic particles on pre-prepared adsorbents, synthesis of adsorbents on pre-prepared magnetic particles, and co-synthesis of adsorbents and magnetic particles. The improvements in these new methods make conventional synthesis more energy saving, more efficient, and simpler in process while maintaining or increasing the adsorption performance. Advanced methods have overcome 
the negative aspects of compositing, such as the coverage of adsorption sites by the magnetic substance, through control of material structures and/or enhancing the adsorption ability of magnetic particles.

Despite the long history of magnetic adsorbents, there are still issues with their synthesis methods that need to be addressed. Primarily, the improvement of the magnetic adsorbent synthesis method to realize effective and uniform compositing is still necessary. The yields of the magnetic adsorbents are not always stated, which has a significant impact on the process simplicity and material cost. In addition, a thorough investigation is needed to enable the design and control of magnetic adsorbent structures to achieve the intensive and selective removal of specific pollutants. Moreover, the development of simulations and observations to understand the synthesis process and adsorption process is still challenging; however, it is expected that this will provide greater insight into the design of ideal magnetic adsorbents, through information on the relationship between the composite structure and performance. Finally, further improvement in reusability is essential for realizing an efficient, economical, and environmentally friendly synthesis method for magnetic adsorbents, which is required to expand applicable cases in social implementation.

Author Contributions: Conceptualization, R.I. and L.L.; methodology, V.P., R.Y., S.N., T.H., R.I., L.K. and L.L.; resources, V.P., R.Y., S.N., T.H., R.I., L.K. and L.L.; writing-original draft preparation, V.P., R.Y., T.H. and L.K.; writing-review and editing, R.I. and L.L.; visualization, V.P., T.H. and L.K.; supervision, R.I. and L.L. All authors have read and agreed to the published version of the manuscript.

Funding: This research was funded by JST SICORP (Grant Number JPMJSC18H1) and the National Key Research and Development Program of China (No. 2017YFE0127100).

Institutional Review Board Statement: Not applicable.

Informed Consent Statement: Not applicable.

Data Availability Statement: No new data were created or analyzed in this study. Data sharing is not applicable.

Acknowledgments: The authors appreciate the support from JST SICORP (Grant Number JPMJSC18H1), Japan and from the National Key Research and Development Program of China (No. 2017YFE0127100).

Conflicts of Interest: The authors declare no conflict of interest.

\section{References}

1. Rashid, R.; Shafiq, I.; Akhter, P.; Iqbal, M.J.; Hussain, M. A state-of-the-art review on wastewater treatment techniques: The effectiveness of adsorption method. Environ. Sci. Pollut. Res. 2021, 28, 9050-9066. [CrossRef] [PubMed]

2. Giakisikli, G.; Anthemidis, A.N. Magnetic materials as sorbents for metal/metalloid preconcentration and/or separation. A review. Anal. Chim. Acta 2013, 789, 1-16. [CrossRef] [PubMed]

3. Robinson, P.J.; Dunnill, P.; Lilly, M.D. The properties of magnetic supports in relation to immobilized enzyme reactors. Biotechnol. Bioeng. 1973, 15, 603-606. [CrossRef]

4. de Latour, C.; Kolm, H.H. High gradient magnetic separation A water-treatment alternative. J. Am. Water Work. Assoc. 1976, 78, 325-327. [CrossRef]

5. Booker, N.A.; Keir, D.; Priestley, A.J.; Ritchie, C.B.; Sudarmana, D.L.; Woods, M.A. Sewage clarification with magnetite particles. Water Sci. Technol. 1991, 23, 1703-1712. [CrossRef]

6. Matei, E.; Predescu, A.; Vasile, E.; Predescu, A. Properties of magnetic iron oxides used as materials for wastewater treatment. J. Phys. Conf. Ser. 2011, 304, 012022. [CrossRef]

7. Gutierrez, A.M.; Dziubla, T.D.; Hilt, J.Z. Recent advances on iron oxide magnetic nanoparticles as sorbents of organic pollutants in water and wastewater treatment. Rev. Environ. Health 2017, 32, 111-117. [CrossRef]

8. $\mathrm{Wu}, \mathrm{W} . ; \mathrm{He}, \mathrm{Q} . ;$ Jiang, C. Magnetic iron oxide nanoparticles: Synthesis and surface functionalization strategies. Nanoscale Res. Lett. 2008, 3, 397-415. [CrossRef]

9. Zhang, J.; Lin, S.; Han, M.; Su, Q.; Xia, L.; Hui, Z. Adsorption properties of magnetic magnetite nanoparticle for coexistent Cr(VI) and $\mathrm{Cu}(\mathrm{II})$ in mixed solution. Water 2020, 12, 446. [CrossRef] 
10. Lu, A.H.; Salabas, E.L.; Schüth, F. Magnetic nanoparticles: Synthesis, protection, functionalization, and application. Angew. Chem. Int. Ed. 2007, 46, 1222-1244. [CrossRef]

11. de Dios, A.S.; Díaz-García, M.E. Multifunctional nanoparticles: Analytical prospects. Anal. Chim. Acta 2010, 666, 1-22. [CrossRef] [PubMed]

12. Phouthavong, V.; Manakasettharn, S.; Viboonratanasri, D.; Buajarern, S.; Prompinit, P.; Sereenonchai, K. Colorimetric determination of trace orthophosphate in water by using C18-functionalized silica coated magnetite. Sci. Rep. 2021, 11, 23073. [CrossRef] [PubMed]

13. Chen, L.; Wang, T.; Tong, J. Application of derivatized magnetic materials to the separation and the preconcentration of pollutants in water samples. TrAC Trends Anal. Chem. 2011, 30, 1095-1108. [CrossRef]

14. Petcharoen, K.; Sirivat, A. Synthesis and characterization of magnetite nanoparticles via the chemical co-precipitation method. Mater. Sci. Eng. B 2012, 177, 421-427. [CrossRef]

15. Tu, Y.-J.; You, C.F.; Chang, C.K.; Chen, M.H. Application of magnetic nano-particles for phosphorus removal/recovery in aqueous solution. J. Taiwan Inst. Chem. Eng. 2015, 46, 148-154. [CrossRef]

16. Hou, Y.; Yu, J.; Gao, S. Solvothermal reduction synthesis and characterization of superparamagnetic magnetite nanoparticles. J. Mater. Chem. 2003, 13, 1983-1987. [CrossRef]

17. Zhao, F.; Zhang, B.; Feng, L. Preparation and magnetic properties of magnetite nanoparticles. Mater. Lett. 2012, 68, 112-114. [CrossRef]

18. Lakshmanan, R.; Okoli, C.; Boutonnet, M.; Järås, S.; Rajarao, G.K. Microemulsion prepared mangetic nanoparticles for phosphate removal: Time efficient studies. J. Environ. Chem. Eng. 2014, 2, 185-189. [CrossRef]

19. Es'haghzade, Z.; Pajootan, E.; Bahrami, H.; Arami, M. Facile synthesis of $\mathrm{Fe}_{3} \mathrm{O}_{4}$ nanoparticles via aqueous based electrochemical route for heterogeneous electro-Fenton removal of azo dyes. J. Taiwan Inst. Chem. Eng. 2017, 71, 91-105. [CrossRef]

20. Miao, F.; Hua, W.; Hu, L.; Huang, K. Magnetic $\mathrm{Fe}_{3} \mathrm{O}_{4}$ nanoparticles prepared by a facile and green microwave-assisted approach. Mater. Lett. 2011, 65, 1031-1033. [CrossRef]

21. Shalaby, M.; Madkour, F.F.; El-Kassas, H.Y.; Mohamed, A.A.; Elgarahyet, A.M. Green synthesis of recyclable iron oxide nanoparticles using Spirulina platensis microalgae for adsorptive removal of cationic and anionic dyes. Environ. Sci. Pollut. Res. 2021, 28, 65549-65572. [CrossRef] [PubMed]

22. Shalaby, M.; Madkour, F.F.; El-Kassas, H.Y.; Mohamed, A.A.; Elgarahyet, A.M. Microwave enhanced sorption of methylene blue dye onto bio-synthesized iron oxide nanoparticles: Kinetics, isotherms, and thermodynamics studies. Int. J. Phytoremediation 2021, in press. [CrossRef] [PubMed]

23. Bolto, B.A.; Dixon, D.R.; Eldridge, R.J.; Swinton, E.A.; Weiss, D.E.; Willis, D. The use of magnetic polymers in water treatment. J. Polym. Sci. 1975, 49, 211-219. [CrossRef]

24. Bolto, B.A.; Dixon, D.R.; Eldridge, R.J. Graft polymerization on magnetic polymer substrates. J. Appl. Polym. Sci. 1978, 22, 1977-1982. [CrossRef]

25. Chen, W.Y.; Anderson, P.R.; Holsen, T.M. Recovery and recycle of metals from wastewater with a magnetite-based adsorption process. Res. J. Water Pollut. Control Fed. 1996, 63, 958-964.

26. Wang, Z.; Xing, M.; Fang, W.; Wu, D. One-Step synthesis of magnetite core/zirconia shell nanocomposite for high efficiency removal of phosphate from water. Appl. Surf. Sci. 2016, 366, 67-77. [CrossRef]

27. Li, Q.; Yang, F.; Zhang, J.; Zhou, C. Magnetic $\mathrm{Fe}_{3} \mathrm{O}_{4} / \mathrm{MnO}_{2}$ core-shell nano-composite for removal of heavy metals from wastewater. SN Appl. Sci. 2020, 2, 1375. [CrossRef]

28. Oliveira, L.C.A.; Petkowicz, D.I.; Smaniotto, A.; Pergher, S.B.C. Magnetic zeolites: A new adsorbent for removal of metallic contaminants from water. Water Res. 2004, 38, 3699-3704. [CrossRef]

29. Hagio, T.; Kunishi, H.; Yamaoka, K.; Kamimoto, Y.; Ichino, R. Seed-Assisted synthesis of magnetic faujasite-type zeolite and its adsorption performance. Nanosci. Nanotechnol. Lett. 2018, 10, 862-867. [CrossRef]

30. Hagio, T.; Nijpanich, S.; Kunishi, H.; Yamaoka, K.; Phouthavong, V.; Kamimoto, Y.; Ichino, R.; Iwai, K. Synthesis of MOR zeolite/magnetite composite via seed assisted method. J. Nanosci. Nanotechnol. 2019, 19, 6841-6848. [CrossRef]

31. Phouthavong, V.; Hiraiwa, M.; Hagio, T.; Nijpanich, S.; Chounlamany, V.; Nishihama, T.; Kamimoto, Y.; Ichino, R. Magnetic BEA-type zeolites: Preparation by dry-gel conversion method and assessment of dye removal performance. J. Mater. Cycles Waste Manag. 2020, 22, 375-382. [CrossRef]

32. Fadillah, G.; Yudha, S.P.; Sagadevan, S.; Fatimah, I.; Muraza, O. Magnetic iron oxide/clay nanocomposites for adsorption and catalytic oxidation in water treatment applications. Open Chem. 2020, 18, 1148-1166. [CrossRef]

33. Jung, K.-W.; Choi, B.H.; Jeong, T.-U.; Ahn, K.-H. Facile synthesis of magnetic biochar $/ \mathrm{Fe}_{3} \mathrm{O}_{4}$ nanocomposites using electromagnetization technique and its application on the removal of acid orange 7 from aqueous media. Bioresour. Technol. 2016, 220, 672-676. [CrossRef]

34. Nijpanich, S.; Morihashi, R.; Hagio, T.; Kamimoto, Y.; Ichino, R. Synthesis of magnetic activated carbon based on a magnetite/butyl glycidyl ether-diluted bisphenol A/diethylenetriamine epoxy resin system. Nanosci. Nanotechnol. Lett. 2018, 10, 843-848. [CrossRef]

35. Li, Y.; Zhang, X.; Zhang, P.; Liu, X.; Han, L. Facile fabrication of magnetic bio-derived chars by co-mixing with $\mathrm{Fe}_{3} \mathrm{O}_{4}$ nanoparticles for effective $\mathrm{Pb}^{2+}$ adsorption: Properties and mechanism. J. Clean. Prod. 2020, 262, 121350. [CrossRef] 
36. Meral, K.; Metın, Ö. Graphene oxide-magnetite nanocomposite as an efficient and magnetically separable adsorbent for methylene blue removal from aqueous solution. Turk. J. Chem. 2014, 38, 775-782. [CrossRef]

37. Li, Y.; Wu, M.; Wang, B.; Wu, Y.; Ma, M.; Zhang, X. Synthesis of magnetic lignin-based hollow microspheres: A highly adsorptive and reusable adsorbent derived from renewable resources. ACS Sustain. Chem. Eng. 2016, 4, 5523-5532. [CrossRef]

38. Nata, I.F.; Wicakso, D.R.; Mirwan, A.; Irawan, C.; Ramadhani, D.; Ursulla. Selective adsorption of Pb(II) ion on amine-rich functionalized rice husk magnetic nanoparticles biocomposites in aqueous solution. J. Environ. Chem. Eng. 2020, 8, 104339. [CrossRef]

39. Charpentier, T.V.J.; Neville, A.; Lanigan, J.L.; Barker, R.; Smith, M.J.; Richardson, T. Preparation of magnetic carboxymethylchitosan nanoparticles for adsorption of heavy metal ions. ACS Omega 2016, 1, 77-83. [CrossRef]

40. Lee, P.L.; Sun, Y.C.; Ling, Y.C. Magnetic nano-adsorbent integrated with lab-on-valve system for trace analysis of multiple heavy metals. J. Anal. At. Spectrom. 2009, 24, 320-327. [CrossRef]

41. Liu, L.; Liu, S.; Zhao, L.; Su, G.; Liu, X.; Peng, H.; Xue, J.; Tang, A. Fabrication of novel magnetic core-shell chelating adsorbent for rapid and highly efficient adsorption of heavy metal ions from aqueous solution. J. Mol. Liq. 2020, 313, 113593. [CrossRef]

42. Mohebbi, A.; Farajzadeh, M.A. Chemical synthesis-free and facile preparation of magnetized polyethylene composite and its application as an efficient magnetic sorbent for some pesticides. J. Chromatogr. A 2020, 1625, 461340. [CrossRef] [PubMed]

43. Huang, S.; Xu, J.; Zheng, J.; Zhu, F.; Xie, L.; Ouyang, G. Synthesis and application of magnetic molecularly imprinted polymers in sample preparation. Anal. Bioanal. Chem. 2018, 410, 3991-4014. [CrossRef] [PubMed]

44. Meteku, B.E.; Huang, J.; Zeng, J.; Subhan, F.; Feng, F.; Zhang, Y.; Qiu, Z.; Aslam, S.; Li, G.; Yan, Z. Magnetic metal-organic framework composites for environmental monitoring and remediation. Coord. Chem. Rev. 2020, 413, 213261. [CrossRef]

45. Minh, P.T.; Lebedeva, O.E. Adsorption properties of a magnetite composite with coffee waste. Russ. J. Phys. Chem. A 2018, 92, 2044-2047. [CrossRef]

46. Shehzad, K.; Xie, C.; He, J.; Cai, X.; Xu, W.; Liu, J. Facile synthesis of novel calcined magnetic orange peel composites for efficient removal of arsenite through simultaneous oxidation and adsorption. J. Colloid Interface Sci. 2018, 511, 155-164. [CrossRef]

47. Huang, X.; Kong, L.; Huang, S.; Liu, M.; Li, L. Synthesis of novel magnetic sulfur-doped Fe $\mathrm{O}_{4}$ nanoparticles for efficient removal of $\mathrm{Pb}(\mathrm{II})$. Sci. China Chem. 2018, 61, 164-171. [CrossRef]

48. Liu, J.; Kong, L.; Huang, X.; Liu, M.; Li, L. Removal of arsenic(V) from aqueous solutions using sulfur-doped Fe ${ }_{3} \mathrm{O}_{4}$ nanoparticles. RSC Adv. 2018, 8, 40804. [CrossRef]

49. Kong, L.; Li, Z.; Huang, X.; Huang, S.; Sun, H.; Liu, M.; Li, L. Efficient removal of Pb(II) from water using magnetic Fe 3 S 4 / reduced graphene oxide composites. J. Mater. Chem. A 2017, 5, 19333-19342. [CrossRef]

50. Teja, A.S.; Koh, P.-Y. Synthesis, properties, and applications of magnetic iron oxide nanoparticles. Prog. Cryst. Growth Charact. Mater. 2009, 55, 22-45. [CrossRef]

51. Majidi, S.; Sehrig, F.Z.; Farkhani, S.M.; Goloujeh, M.S.; Akbarzadeh, A. Current methods for synthesis of magnetic nanoparticles. Artif. Cells Nanomed. Biotechnol. 2016, 44, 722-734. [CrossRef] [PubMed]

52. Ali, A.; Shah, T.; Ullah, R.; Zhou, P.; Guo, M.; Ovais, M.; Tan, Z.; Rui, Y.K. Review on recent progress in magnetic nanoparticles: Synthesis, characterization, and diverse applications. Front. Chem. 2021, 9, 629054. [CrossRef] [PubMed]

53. Akbarzadeh, A.; Samiei, M.; Davaran, S. Magnetic nanoparticles: Preparation, physical properties, and applications in biomedicine. Nanoscale Res. Lett. 2012, 7, 144. [CrossRef] [PubMed]

54. García-Merino, B.; Bringas, E.; Ortiz, I. Synthesis and applications of surface-modified magnetic nanoparticles: Progress and future prospects. Rev. Chem. Eng. 2021, 000010151520200072. [CrossRef]

55. Reshadi, M.A.M.; Bazargan, A.; McKay, G. A review of the application of adsorbents for landfill leachate treatment: Focus on magnetic adsorption. Sci. Total Environ. 2020, 731, 138863. [CrossRef]

56. Shukla, S.; Khan, R.; Daverey, A. Synthesis and characterization of magnetic nanoparticles, and their applications in wastewater treatment: A review. Environ. Technol. Innov. 2021, 24, 101924. [CrossRef]

57. Abdullah, N.H.; Shameli, K.; Abdullah, E.C.; Abdullah, L.C. Solid matrices for fabrication of magnetic iron oxide nanocomposites: Synthesis, properties, and application for the adsorption of heavy metal ions and dyes. Compos. B Eng. 2019 , 162, 538-568. [CrossRef]

58. Abdel Maksoud, M.I.A.; Elgarahy, A.M.; Farrell, C.; Al-Muhtaseb, A.H.; Rooney, D.W.; Osman, A.I. Insight on water remediation application using magnetic nanomaterials and biosorbents. Coord. Chem. Rev. 2020, 403, 213096. [CrossRef]

59. de Vicente, I.; Merino-Martos, A.; Cruz-Pizarro, L.; de Vicente, J. On the use of magnetic nano and microparticles for lake restoration. J. Hazard. Mater. 2010, 181, 375-381. [CrossRef]

60. Choi, J.; Chung, J.; Lee, W.; Kim, J.-O. Phosphorous adsorption on synthesized magnetite in wastewater. J. Ind. Eng. Chem. 2016, 34, 198-203. [CrossRef]

61. Cheng, W.; Xu, J.; Wang, Y.; Wu, F.; Xu, X.; Li., J. Dispersion-Precipitation synthesis of nanosized magnetic iron oxide for efficient removal of arsenite in water. J. Colloid Interface Sci. 2015, 445, 93-101. [CrossRef] [PubMed]

62. Nikraftar, N.; Ghorbani, F. Adsorption of As(V) using modified magnetic nanoparticles with ascorbic acid: Optimization by response surface methodology. Water Air Soil Pollut. 2016, 227, 178. [CrossRef]

63. Ahmed, M.A.; Ali, S.M.; El-Deka, S.I.; Galal, A. Magnetite-Hematite nanoparticles prepared by green methods for heavy metal ions removal from water. Mater. Sci. Eng. B 2013, 178, 744-751. [CrossRef] 
64. Iwahori, K.; Watanabe, J.; Tani, Y.; Seyama, H.; Miyata, N. Removal of heavy metal cations by biogenic magnetite nanoparticles produced in Fe(III)-reducing microbial enrichment cultures. J. Biosci. Bioeng. 2014, 117, 333-335. [CrossRef] [PubMed]

65. Rajput, S.; Pittman, C.U., Jr.; Mohan, D. Magnetic magnetite $\left(\mathrm{Fe}_{3} \mathrm{O}_{4}\right)$ nanoparticle synthesis and applications for lead $\left(\mathrm{Pb}^{2+}\right)$ and chromium $\left(\mathrm{Cr}^{6+}\right)$ removal from water. J. Colloid Interface Sci. 2016, 468, 334-346. [CrossRef] [PubMed]

66. Feng, D.; Aldrich, C.; Tan, H. Removal of heavy metal ions by carrier magnetic separation of adsorptive particulates. Hydrometallurgy 2000, 56, 359-368. [CrossRef]

67. Nah, I.W.; Hwang, K.-Y.; Jeon, C.; Choi, H.B. Removal of Pb ion from water by magnetically modified zeolite. Miner. Eng. 2006, 19, 1452-1455. [CrossRef]

68. Paris, E.C.; Malafatti, J.O.D.; Musetti, H.C.; Manzoli, A.; Zenatti, A.; Escote, M.T. Faujasite zeolite decorated with cobalt ferrite nanoparticles for improving removal and reuse in $\mathrm{Pb}^{2+}$ ions adsorption. Chin. J. Chem. Eng. 2020, 28, 1884-1890. [CrossRef]

69. Fungaro, D.A.; Graciano, J.E.A. Adsorption of zinc ions from water using zeolite/iron oxide composites. Adsorp. Sci. Technol. 2007, 25, 729-740. [CrossRef]

70. Fungaro, D.A.; Yamaura, M.; Craesmeyer, G.R. Uranium removal from aqueous solution by zeolite from fly ash-iron oxide magnetic nanocomposite. Int. Rev. Chem. Eng. 2012, 4, 353-358.

71. Bessa, R.A.; Costa, L.S.; Oliveira, C.P.; Bohn, F.; do Nascimento, R.F.; Sasaki, J.M.; Loiola, A.R. Kaolin-Based magnetic zeolites A and P as water softeners. Microporous Mesoporous Mater. 2017, 245, 64-72. [CrossRef]

72. Gaffer, A.; Kahlawy, A.A.A.; Aman, D. Magnetic zeolite-natural polymer composite for adsorption of chromium (VI). Egypt. J. Pet. 2017, 26, 995-999. [CrossRef]

73. Anbia, M.; Rahimi, F. Adsorption of platinum(IV) from an aqueous solution with magnetic cellulose functionalized with thiol and amine as a nano-active adsorbent. J. Appl. Polym. Sci. 2017, 134, 45361. [CrossRef]

74. Le, V.T.; Doan, V.D.; Nguyen, D.D.; Nguyen, H.T.; Ngo, Q.P.; Tran, T.K.N.; Le, H.S. A novel cross-linked magnetic hydroxyapatite/chitosan composite: Preparation, characterization, and application for Ni(II) ion removal from aqueous solution. Water Air Soil Pollut. 2018, 229, 101. [CrossRef]

75. Galhoum, A.A. Facile synthesis of functionalized polyglycidyl methacrylate-magnetic nanocomposites for enhanced uranium sorption. RSC Adv. 2019, 9, 38783. [CrossRef]

76. Tian, N.; Wu, J.; Wang, J.; Dai, W. Development of a novel core-shell magnetic $\mathrm{Fe}_{3} \mathrm{O}_{4} @$ CMC@ZIF-8-OH composite with outstanding rubidium-ion capacity. J. Chem. Eng. Data 2019, 64, 5716-5724. [CrossRef]

77. Dinari, M.; Shirani, M.A.; Maleki, M.H.; Tabatabaeian, R. Green cross-linked bionanocomposite of magnetic layered double hydroxide/guar gum polymer as an efficient adsorbent of $\mathrm{Cr}(\mathrm{VI})$ from aqueous solution. Carbohydr. Polym. 2020, 236, 116070. [CrossRef] [PubMed]

78. Chen, C.; Gunawan, P.; $\mathrm{Xu}$, R. Self-Assembled $\mathrm{Fe}_{3} \mathrm{O}_{4}$-layered double hydroxide colloidal nanohybrids with excellent performance for treatment of organic dyes in water. J. Mater. Chem. 2011, 21, 1218-1225. [CrossRef]

79. Hu, S.C.; Shi, F.; Liu, J.X.; Yu, L.; Liu, S.H. Magnetic mesoporous iron oxide/silica composite aerogels with high adsorption ability for organic pollutant removal. J. Porous Mater. 2016, 23, 655-661. [CrossRef]

80. Fungaro, D.A.; Yamaura, M.; Carvalho, T.E.M. Adsorption of anionic dyes from aqueous solution on zeolite from fly ash-iron oxide magnetic nanocomposite. J. At. Mol. Sci. 2011, 2, 305-316. [CrossRef]

81. Rashid, M.; Price, N.T.; Pinilla, M.Á.G.; O'Shea, K.E. Effective removal of phosphate from aqueous solution using humic acid coated magnetite nanoparticles. Water Res. 2017, 123, 353-360. [CrossRef] [PubMed]

82. Wu, H.; Xia, T.; Yin, L.; Ji, Y. Adsorption of iodide from an aqueous solution via calcined magnetite-activated carbon/MgAl-layered double hydroxide. Chem. Phys. Lett. 2021, 774, 138612. [CrossRef]

83. Kumar, A.S.K.; Jiang, S.J.; Warchoł, J.K. Synthesis and characterization of two-dimensional transition metal dichalcogenide magnetic $\mathrm{MoS}_{2} @ \mathrm{Fe}_{3} \mathrm{O}_{4}$ Nanoparticles for Adsorption of $\mathrm{Cr}(\mathrm{VI}) / \mathrm{Cr}(\mathrm{III})$. ACS Omega 2017, 2, 6187-6200. [CrossRef] [PubMed]

84. Geng, J.; Gu, F.; Chang, J. Fabrication of magnetic lignosulfonate using ultrasonic-assisted in situ synthesis for efficient removal of $\mathrm{Cr}(\mathrm{VI})$ and Rhodamine B from wastewater. J. Hazard. Mater. 2019, 375, 174-181. [CrossRef]

85. Eivazzadeh-Keihan, R.; Radinekiyan, F.; Asgharnasl, S.; Maleki, A.; Bahreinizad, H. A natural and eco-friendly magnetic nanobiocomposite based on activated chitosan for heavy metals adsorption and the in-vitro hyperthermia of cancer therapy. $J$. Mater. Res. Technol. 2020, 9, 12244-12259. [CrossRef]

86. Sheng, L.; Zhou, L.; Huang, Z.; Liu, Z.; Chen, Q.; Huang, G.; Adesina, A.A. Facile synthesis of magnetic chitosan nano-particles functionalized with N/O-containing groups for efficient adsorption of U(VI) from aqueous solution. J. Radioanal. Nucl. Chem. 2016, 310, 1361-1371. [CrossRef]

87. Amini, A.; Khajeh, M.; Oveisi, A.R.; Daliran, S.; Ghaffari-Moghaddam, M.; Delarami, H.S. A porous multifunctional and magnetic layered graphene oxide/3D mesoporous MOF nanocomposite for rapid adsorption of uranium(VI) from aqueous solutions. $J$. Ind. Eng. Chem. 2021, 93, 322-332. [CrossRef]

88. Zargar, B.; Khazaeifar, A. Synthesis of an ion-imprinted sorbent by surface imprinting of magnetized carbon nanotubes for determination of trace amounts of cadmium ions. Microchim. Acta 2017, 184, 4521-4529. [CrossRef]

89. Wang, Z.; Ding, S.; Li, Z.; Li, F.; Zhao, T.; Li, J.; Lin, H.; Chen, C. Synthesis of a magnetic polystyrene-based cation-exchange resin and its utilization for the efficient removal of cadmium (II). Water Sci. Technol. 2018, 2017, 770-781. [CrossRef]

90. Dong, T.; Xing, H.; Wu, H.; Lv, Y.; Wu, L.; Mi, S.; Yang, L. Preparation of magnetic Levextrel resin for cadmium(II) removal. Environ. Technol. Innov. 2021, 23, 101657. [CrossRef] 
91. Wan, K.; Wang, G.; Xue, S.; Xiao, Y.; Fan, J.; Li, L.; Miao, Z. Preparation of humic acid/L-cysteine-codecorated magnetic Fe ${ }_{3} \mathrm{O}_{4}$ nanoparticles for selective and highly efficient adsorption of mercury. ACS Omega 2021, 6, 7941-7950. [CrossRef] [PubMed]

92. Xie, Y.; Qian, D.; Wu, D.; Ma, X. Magnetic halloysite nanotubes/iron oxide composites for the adsorption of dyes. Chem. Eng. J. 2011, 168, 959-963. [CrossRef]

93. Paz, R.; Viltres, H.; Gupta, N.K.; Leyva, C. Fabrication of magnetic cerium-organic framework-activated carbon composite for charged dye removal from aqueous solutions. J. Mol. Liq. 2021, 337, 116578. [CrossRef]

94. Abou Taleb, M.F.; Abou El Fadl, F.I.; Albalwi, H. Adsorption of toxic dye in wastewater onto magnetic NVP/CS nanocomposite hydrogels synthesized using gamma radiation. Sep. Purif. Technol. 2021, 266, 118551. [CrossRef]

95. Cheng, J.; Chang, P.R.; Zheng, P.; Ma, X. Characterization of magnetic carbon nanotube-cyclodextrin composite and its adsorption of dye. Ind. Eng. Chem. Res. 2014, 53, 1415-1421. [CrossRef]

96. Stoia, M.; Păcurariu, C.; Istratie, R.; Nižňansky, D. Solvothermal synthesis of magnetic $\mathrm{Fe}_{\mathrm{x}} \mathrm{O}_{\mathrm{y}} / \mathrm{C}$ nanocomposites used as adsorbents for the removal of methylene blue from wastewater. J. Therm. Anal. Calorim. 2015, 121, 989-1001. [CrossRef]

97. Panasenko, A.; Pirogovskaya, P.; Tkachenko, I.; Ivannikov, S.; Arefieva, O.; Marchenko, Y. Synthesis and characterization of magnetic silica/iron oxide composite as a sorbent for the removal of methylene blue. Mater. Chem. Phys. 2020, 245, 122759. [CrossRef]

98. Abdullah, N.H.; Shameli, K.; Abdullah, E.C.; Abdullah, L.C. Low cost and efficient synthesis of magnetic iron oxide/activated sericite nanocomposites for rapid removal of methylene blue and crystal violet dyes. Mater. Charact. 2020, 163, 110275. [CrossRef]

99. Ge, H.; Zhang, Z.; Zhao, X.; Li, H.; Sun, J.; Jv, X. Adsorption performance of organic dyes in single and binary systems onto poly(itaconic acid)/magnetite sepiolite composite prepared via the green synthetic methods. Can. J. Chem. Eng. 2021, 99, S157-S167. [CrossRef]

100. Ain, Q.U.; Rasheed, U.; Yaseen, M.; Zhang, H.; He, R.; Tong, Z. Fabrication of magnetically separable 3-acrylamidopropyltrimethylammoniu chloride intercalated bentonite composite for the efficient adsorption of cationic and anionic dyes. Appl. Surf. Sci. 2020, 514, 145929. [CrossRef]

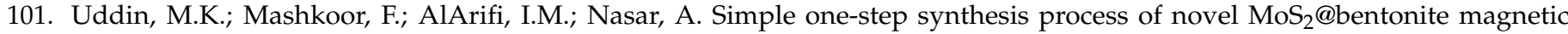
nanocomposite for efficient adsorption of crystal violet from aqueous solution. Mater. Res. Bull. 2021, 139, 111279. [CrossRef]

102. Zhu, X.; Liu, Y.; Zhou, C.; Zhang, S.; Chen, J. Novel and high-performance magnetic carbon composite prepared from waste hydrochar for dye removal. ACS Sustain. Chem. Eng. 2014, 2, 969-977. [CrossRef]

103. Qin, Y.; Long, M.; Tan, B.; Zhou, B. RhB adsorption performance of magnetic adsorbent $\mathrm{Fe}_{3} \mathrm{O}_{4} / \mathrm{RGO}$ composite and its regeneration through a fenton-like reaction. Nano-Micro Lett. 2014, 6, 125-135. [CrossRef]

104. Shi, S.; Fan, Y.; Huang, Y. Facile low temperature hydrothermal synthesis of magnetic mesoporous carbon nanocomposite for adsorption removal of ciprofloxacin antibiotics. Ind. Eng. Chem. Res. 2013, 52, 2604-2612. [CrossRef]

105. Liu, Q.; Zhong, L.-B.; Zhao, Q.-B.; Frear, C.; Zheng, Y.-M. Synthesis of $\mathrm{Fe}_{3} \mathrm{O}_{4}$ / polyacrylonitrile composite electrospun nanofiber mat for effective adsorption of tetracycline. ACS Appl. Mater. Interfaces 2015, 7, 14573-14583. [CrossRef] [PubMed]

106. Nezhadali, A.; Koushali, S.E.; Divsar, F. Synthesis of polypyrrole-Chitosan magnetic nanocomposite for the removal of carbamazepine from wastewater: Adsorption isotherm and kinetic study. J. Environ. Chem. Eng. 2021, 9, 105648. [CrossRef]

107. Palakeeti, B.; Reddy, K.V.; Gobi, K.V.; Rao, P.N.; Chinta, J.P. Simple and efficient method for the quantification of antiepileptic drugs in human plasma by using magnetic graphene oxide- $\beta$-cyclodextrin composite as a sorbent. Futur. J. Pharm. Sci. 2021, 7, 93. [CrossRef]

108. Ieamviteevanich, P.; Palaporn, D.; Chanlek, N.; Poo-arporn, Y.; Mongkolthanaruk, W.; Eichhorn, S.J.; Pinitsoontorn, S. Carbon nanofiber aerogel/magnetic core-shell nanoparticle composites as recyclable oil sorbents. ACS Appl. Nano Mater. 2020, 3 , 3939-3950. [CrossRef]

109. Ahmed, S.; Zhang, Y.; Wu, B.; Zheng, Z.; Leung, C.F.; Choy, T.; Kwok, Y.; Lo, I.M.C. Scaled-Up development of magnetically recyclable $\mathrm{Fe}_{3} \mathrm{O}_{4} / \mathrm{La}(\mathrm{OH})_{3}$ composite for river water phosphate removal: From bench-scale to pilot-scale study. Sci. Total Environ. 2021, 791, 148281. [CrossRef]

110. Cao, J.; Liu, X.W.; Fu, R.; Tan, Z. Magnetic P zeolites: Synthesis, characterization and the behavior in potassium extraction from seawater. Sep. Purif. Technol. 2008, 63, 92-100. [CrossRef]

111. Aono, H.; Kaji, N.; Itagaki, Y.; Johan, E.; Matsue, N. Synthesis of mordenite and its composite material using chemical reagents for Cs decontamination. J. Ceram. Soc. Jpn. 2016, 124, 617-623. [CrossRef]

112. Huang, Y.F.; Li, Y.; Jiang, Y.; Yan, X.P. Magnetic immobilization of amine-functionalized magnetite microspheres in a knotted reactor for on-line solid-phase extraction coupled with ICP-MS for speciation analysis of trace chromium. J. Anal. At. Spectrom. 2010, 25, 1467-1474. [CrossRef]

113. Wang, T.; Zhang, L.; Li, C.; Yang, W.; Song, T.; Tang, C.; Meng, Y.; Dai, S.; Wang, H.; Chai, L.; et al. Synthesis of core-shell magnetic $\mathrm{Fe}_{3} \mathrm{O}_{4} @$ poly(m-phenylenediamine) particles for chromium reduction and adsorption. Environ. Sci. Technol. 2015, 49, 5654-5662. [CrossRef] [PubMed]

114. Wang, Y.; Luo, X.; Tang, J.; Hu, X.; Xu, Q.; Yang, C. Extraction and preconcentration of trace levels of cobalt using functionalized magnetic nanoparticles in a sequential injection lab-on-valve system with detection by electrothermal atomic adsorption spectrometry. Anal. Chim. Acta 2012, 713, 92-96. [CrossRef] [PubMed]

115. Jilin, C.; Guihuan, C.; Hongfei, G.; Jianxin, C. Synthesis and characterization of magnetic ZSM-5 zeolite. Trans. Tianjin Univ. 2013, 19, 326-331. 
116. Zhang, F.; Song, Y.; Song, S.; Zhang, R.; Hou, W. Synthesis of magnetite-graphene oxide-layered double hydroxide composites and applications for the removal of $\mathrm{Pb}(\mathrm{II})$ and 2,4-dichlorophenoxyacetic acid from aqueous solutions. ACS Appl. Mater. Interfaces 2015, 7, 7251-7263. [CrossRef]

117. Zhang, J.; Zhai, S.; Li, S.; Xiao, Z.; Song, Y.; An, Q.; Tian, G. Pb(II) removal of $\mathrm{Fe}_{3} \mathrm{O}_{4} @ \mathrm{SiO}_{2}-\mathrm{NH}_{2}$ core-shell nanomaterials prepared via a controllable sol-gel process. Chem. Eng. J. 2013, 215-216, 461-471. [CrossRef]

118. Liu, H.; Peng, S.; Shu, L.; Chen, T.; Bao, T.; Frost, R.L. Magnetic zeolite NaA: Synthesis, characterization based on metakaolin and its application for the removal of $\mathrm{Cu}^{2+}, \mathrm{Pb}^{2+}$. Chemosphere 2013, 91, 1539-1546. [CrossRef]

119. Jiang, X.; Su, S.; Rao, J.; Li, S.; Lei, T.; Bai, H.; Wang, S.; Yang, X. Magnetic metal-organic framework $\left(\mathrm{Fe}_{3} \mathrm{O}_{4} @ Z \mathrm{ZIF}-8\right)$ core-shell composite for the efficient removal of $\mathrm{Pb}$ (II) and $\mathrm{Cu}$ (II) from water. J. Environ. Chem. Eng. 2021, 9, 105959. [CrossRef]

120. Zhang, Y.; Ni, S.; Wang, X.; Zhang, W.; Lagerquist, L.; Qin, M.; Willför, S.; Xu, C.; Fatehi, P. Ultrafast adsorption of heavy metal ions onto functionalized lignin-based hybrid magnetic nanoparticles. Chem. Eng. J. 2019, 372, 82-91. [CrossRef]

121. Tavares, D.S.; Daniel-da-Silva, A.L.; Lopes, C.B.; Silva, N.J.O.; Amaral, V.S.; Rocha, J.; Pereira, E.; Trindade, T. Efficient sorbents based on magnetite coated with siliceous hybrid shells for removal of mercury ions. J. Mater. Chem. A 2013, 1, 8134-8143. [CrossRef]

122. Alonso, E.V.; Guerrero, M.M.L.; Cueto, P.C.; Benítez, J.B.; Pavón, J.M.C.; de Torres, A.G. Development of an on-line solid phase extraction method based on new functionalized magnetic nanoparticles. Use in the determination of mercury in biological and sea-water samples. Talanta 2016, 153, 228-239. [CrossRef] [PubMed]

123. Huang, L.; Shuai, Q. Facile approach to prepare sulfur-functionalized magnetic amide-linked organic polymers for enhanced $\mathrm{Hg}$ (II) removal from water. ACS Sustain. Chem. Eng. 2019, 7, 9957-9965. [CrossRef]

124. Wei, W.; Li, A.; Pi, S.; Wang, Q.; Zhou, L.; Yang, J.; Ma, F.; Ni, B.J. Synthesis of core-shell magnetic nanocomposite Fe ${ }_{3} \mathrm{O}_{4} @ \mathrm{microbial}$ extracellular polymeric substances for simultaneous redox sorption and recovery of silver ions as silver nanoparticles. ACS Sustain. Chem. Eng. 2018, 6, 749-756. [CrossRef]

125. Lai, Z.; Xuan, Z.; Yu, S.; Zhang, Z.; Cao, Y.; Zhao, Y.; Li, Y.; Luo, J.; Li, X. Synthesis of magnetic-carbon sorbent for removal of U(VI) from aqueous solution. J. Radioanal. Nucl. Chem. 2019, 322, 2079-2089. [CrossRef]

126. Zhao, M.; Cui, Z.; Pan, D.; Fan, F.; Tang, J.; Hu, Y.; Xu, Y.; Zhang, P.; Li, P.; Kong, X.Y.; et al. An efficient uranium adsorption magnetic platform based on amidoxime-functionalized flower-like $\mathrm{Fe}_{3} \mathrm{O}_{4} @ \mathrm{TiO}_{2}$ core-shell microspheres. ACS Appl. Mater. Interfaces 2021, 13, 17931-17939. [CrossRef] [PubMed]

127. Wang, D.; Guan, K.; Bai, Z.; Liu, F. Facile preparation of acid-resistant magnetite particles for removal of Sb(III) from strong acidic solution. Sci. Technol. Adv. Mater. 2016, 17, 80-88. [CrossRef] [PubMed]

128. Roto, R.; Yusran, Y.; Kuncaka, A. Magnetic adsorbent of $\mathrm{Fe}_{3} \mathrm{O}_{4} @ \mathrm{SiO}_{2}$ core-shell nanoparticles modified with thiol group for chloroauric ion adsorption. Appl. Surf. Sci. 2016, 377, 30-36. [CrossRef]

129. Jiang, C.; Sun, Y.; Yu, X.; Zhang, L.; Sun, X.; Gao, Y.; Zhang, H.; Song, D. Removal of sudan dyes from water with C18-functional ultrafine magnetic silica nanoparticles. Talanta 2012, 89, 38-46. [CrossRef] [PubMed]

130. Kubo, M.; Moriyama, R.; Shimada, M. Facile fabrication of HKUST-1 nanocomposites incorporating $\mathrm{Fe}_{3} \mathrm{O}_{4}$ and $\mathrm{TiO}_{2}$ nanoparticles by a spray-assisted synthetic process and their dye adsorption performances. Microporous Mesoporous Mater. 2019, 280, 227-235. [CrossRef]

131. Zheng, J.; Cheng, C.; Fang, W.J.; Chen, C.; Yan, R.W.; Huai, H.X.; Wang, C.C. Surfactant-Free synthesis of a Fe ${ }_{3} \mathrm{O}_{4} @ Z I F-8$ core-shell heterostructure for adsorption of methylene blue. Cryst. Eng. Commun. 2014, 16, 3960-3964. [CrossRef]

132. Far, H.S.; Hasanzadeh, M.; Nashtaei, M.S.; Rabbani, M.; Haji, A.; Moghadam, B.H. PPI-Dendrimer-Functionalized magnetic metal-organic framework $\left(\mathrm{Fe}_{3} \mathrm{O}_{4} @ \mathrm{MOF} @ \mathrm{PPI}\right)$ with high adsorption capacity for sustainable wastewater treatment. ACS Appl. Mater. Interfaces 2020, 12, 25294-25303. [CrossRef]

133. Liu, Y.; Zheng, H.; Han, Y.; Wu, Y.; Wang, Y.; Liu, Y.; Feng, L. Amphiphilic magnetic copolymer for enhanced removal of anionic dyes: Fabrication, application and adsorption mechanism. Colloids Surf. A Physicochem. Eng. Asp. 2021, 623, 126674. [CrossRef]

134. Wei, X.; Wang, Y.; Chen, J.; Liu, Z.; Xu, F.; He, X.; Li, H.; Zhou, Y. Fabrication of di-selective adsorption platform based on deep eutectic solvent stabilized magnetic polydopamine: Achieving di-selectivity conversion through adding $\mathrm{CaCl}_{2}$. Chem. Eng. J. 2021, 421, 127815. [CrossRef]

135. Karbasaki, S.S.; Bagherzade, G.; Maleki, B.; Ghani, M. Fabrication of sulfamic acid functionalized magnetic nanoparticles with denderimeric linkers and its application for microextraction purposes, one-pot preparation of pyrans pigments and removal of malachite green. J. Taiwan Inst. Chem. Eng. 2021, 118, 342-354. [CrossRef]

136. Liu, K.; Huang, L.; Suai, Q. Solvent and catalyst free preparation of sulfonic acid functionalized magnetic covalent organic polymer as efficient adsorbent for malachite green removal. J. Water Process. Eng. 2021, 43, 102306. [CrossRef]

137. Karatapanis, A.E.; Fiamegos, Y.; Stalikas, C.D. Silica-Modified magnetic nanoparticles functionalized with cetylpyridinium bromide for the preconcentration of metals after complexation with 8-hydroxyquinoline. Talanta 2011, 84, 834-839. [CrossRef]

138. Zhang, S.; Niu, H.; Cai, Y.; Shi, Y. Barium alginate caged $\mathrm{Fe}_{3} \mathrm{O}_{4} @ \mathrm{C} 18$ magnetic nanoparticles for the pre-concentration of polycyclic aromatic hydrocarbons and phthalate esters from environmental water samples. Anal. Chim. Acta 2010, 665, 167-175. [CrossRef] [PubMed]

139. Li, Z.; Huang, D.; Fu, C.; Wei, B.; Yu, W.; Deng, C.; Zhang, X. Preparation of magnetic core mesoporous shell microspheres with C18-modified interior pore-walls for fast extraction and analysis of phthalates in water samples. J. Chromatogr. A 2011, 1218, 6232-6239. [CrossRef] [PubMed] 
140. Adivi, F.G.; Hashemi, P.; Tehrani, A.D. Agarose-Coated $\mathrm{Fe}_{3} \mathrm{O}_{4} @ \mathrm{SiO}_{2}$ magnetic nanoparticles modified with sodium dodecyl sulfate, a new promising sorbent for fast adsorption/desorption of cationic drugs. Polym. Bull. 2019, 76, 1239-1256. [CrossRef]

141. Huang, L.; Mao, N.; Yan, Q.; Zhang, D.; Shuai, Q. Magnetic covalent organic frameworks for the removal of diclofenac sodium from water. ACS Appl. Nano Mater. 2020, 3, 319-326. [CrossRef]

142. Su, Y.; Adeleye, A.S.; Huang, Y.; Sun, X.; Dai, C.; Zhou, X.; Zhang, Y.; Keller, A.A. Simultaneous removal of cadmium and nitrate in aqueous media by nanoscale zerovalent iron (nZVI) and Au doped nZVI particles. Water Res. 2014, 63, 102-111. [CrossRef] [PubMed]

143. Stefaniuk, M.; Oleszczuk, P.; Ok, Y.S. Review on nano zerovalent iron (nZVI): From synthesis to environmental applications. Chem. Eng. J. 2016, 287, 618-632. [CrossRef]

144. Kendelewicz, T.; Liu, P.; Doyle, C.S.; Brown, G.E., Jr. Spectroscopic study of the reaction of aqueous $\mathrm{Cr}(\mathrm{VI}) \mathrm{with}_{\mathrm{Fe}} \mathrm{O}_{4}(111)$ surfaces. Surf. Sci. 2000, 469, 144-163. [CrossRef]

145. Yusoff, A.H.M.; Salimi, M.N.; Jamlos, M.F. Critical parametric study on final size of magnetite nanoparticles. IOP Conf. Ser. Mater. Sci. Eng. 2018, 318, 012020. [CrossRef]

146. Gnanaprakash, G.; Mahadevan, S.; Jayakumar, T.; Kalyanasundaram, P.; Philip, J.; Raj, B. Effect of initial pH and temperature of iron salt solutions on formation of magnetite nanoparticles. Mater. Chem. Phys. 2007, 103, 168-175. [CrossRef]

147. Mascolo, M.C.; Pei, Y.; Ring, T.A. Room temperature co-precipitation synthesis of magnetite nanoparticles in a large $\mathrm{pH}$ window with different bases. Materials 2013, 6, 5549-5567. [CrossRef]

148. Hajdú, A.; Illés, E.; Tombácz, E.; Borbáth, I. Surface charging, polyanionic coating and colloid stability of magnetite nanoparticles. Colloids Surf. A Physicochem. Eng. Asp. 2009, 347, 104-108. [CrossRef]

149. Chang, M.; Shih, Y. Synthesis and application of magnetic iron oxide nanoparticles on the removal of Reactive Black 5: Reaction mechanism, temperature and pH effects. J. Environ. Manage. 2018, 224, 235-242. [CrossRef]

150. Maity, D.; Kale, S.N.; Kaul-Ghanekar, R.; Xue, J.-M.; Ding, J. Studies of magnetite nanoparticles synthesized by thermal decomposition of iron (III) acetylacetonate in tri(ethylene glycol). J. Magn. Magn. Mater. 2009, 321, 3093-3098. [CrossRef]

151. Angermann, A.; Töpfer, J. Synthesis of magnetite nanoparticles by thermal decomposition of ferrous oxalate dihydrate. J. Mater. Sci. 2008, 43, 5123-5130. [CrossRef]

152. Lassenberger, A.; Grünewald, T.A.; van Oostrum, P.D.J.; Rennhofer, H.; Amenitsch, H.; Zirbs, R.; Lichtenegger, H.C.; Reimhult, E Monodisperse iron oxide nanoparticles by thermal decomposition: Elucidating particle formation by second-resolved in situ small-angle X-ray scattering. Chem. Mater. 2017, 29, 4511-4522. [CrossRef] [PubMed]

153. Fotukian, S.M.; Barati, A.; Soleymani, M.; Alizadeh, A.M. Solvothermal synthesis of $\mathrm{CuFe}_{2} \mathrm{O}_{4}$ and $\mathrm{Fe}_{3} \mathrm{O}_{4}$ nanoparticles with high heating efficiency for magnetic hyperthermia application. J. Alloys Compd. 2020, 816, 152548. [CrossRef]

154. Luo, X.; Zhang, L. High effective adsorption of organic dyes on magnetic cellulose beads entrapping activated carbon. J. Hazard. Mater. 2009, 171, 340-347. [CrossRef]

155. Metin, Ö.; Aydoğan, Ş.; Meral, K. A new route for the synthesis of graphene oxide- $\mathrm{Fe}_{3} \mathrm{O}_{4}\left(\mathrm{GO}-\mathrm{Fe}_{3} \mathrm{O}_{4}\right)$ nanocomposites and their Schottky diode applications. J. Alloys Compd. 2014, 585, 681-688. [CrossRef]

156. Guo, S.; Sun, S. FePt nanoparticles assembled on graphene as enhanced catalyst for oxygen reduction reaction. J. Am. Chem. Soc. 2012, 134, 2492-2495. [CrossRef] [PubMed]

157. Hosseini, S.M.; Younesi, H.; Bahramifar, N.; Mehraban, Z. A novel facile synthesis of the amine-functionalized magnetic core coated carboxylated nanochitosan shells as an amphoteric nanobiosupport. Carbohydr. Polym. 2019, 221, 174-185. [CrossRef] [PubMed]

158. Mahjour, B.; Shen, Y.; Liu, W.; Cernak, T. A map of the amine-carboxylic acid coupling system. Nature 2020, 580, 71-75. [CrossRef] [PubMed]

159. Shou, J.; Jiang, C.; Wang, F.; Qiu, M.; Xu, Q. Fabrication of $\mathrm{Fe}_{3} \mathrm{O}_{4} / \mathrm{MgAl}$-layered double hydroxide magnetic composites for the effective decontamination of Co(II) from synthetic wastewater. J. Mol. Liq. 2015, 207, 216-223. [CrossRef]

160. Salah El-Din, T.A.; Elzatahry, A.A.; Aldhayan, D.M.; Al-Enizi, A.M.; Al-Deyab, S.S. Synthesis and characterization of magnetite zeolite nano composite. Int. J. Electrochem. Sci. 2011, 6, 6177-6183.

161. Jahangirian, H.; Ismail, M.H.S.; Haron, M.J.; Rafiee-Moghaddam, R.; Shameli, K.; Hosseini, S.; Kalantari, K.; Khandanlou, R.; Gharibshahi, E.; Soltaninejad, S. Synthesis and characterization of Zeolite $/ \mathrm{Fe}_{3} \mathrm{O}_{4}$ nanocomposite by green quick precipitation method. Dig. J. Nanomater. Biostructures 2013, 8, 1405-1413.

162. Shirani, M.; Semnani, A.; Habibollahi, S.; Haddadi, H.; Narimani, M. Synthesis and application of magnetic NaY zeolite composite immobilized with ionic liquid for adsorption desulfurization of fuel using response surface methodology. J. Porous Mater. 2016, 23, 701-712. [CrossRef]

163. Wu, J.H.; Li, X.-S.; Zhao, Y.; Gao, Q.; Guo, L.; Feng, Y.-Q. Titania coated magnetic mesoporous hollow silica microspheres: Fabrication and application to selective enrichment of phosphopeptides. Chem. Commun. 2010, 46, 9031-9033. [CrossRef] [PubMed]

164. Yan, L.; Kong, L.; Qu, Z.; Li, L.; Shen, G. Magnetic biochar decorated with ZnS nanocrystals for Pb(II) removal. ACS Sustain. Chem. Eng. 2015, 3, 125-132. [CrossRef]

165. Chen, B.; Hu, B.; He, M.; Huang, Q.; Zhang, Y.; Zhang, X. Speciation of selenium in cells by HPLC-ICP-MS after (on-chip) magnetic solid phase extraction. J. Anal. At. Spectrom. 2013, 28, 334-343. [CrossRef] 
166. Stöber, W.; Fink, A.; Bohn, E. Controlled growth of monodisperse silica spheres in the micron size range. J. Colloid Interface Sci. 1968, 26, 62-69. [CrossRef]

167. Vacassy, R.; Flatt, R.J.; Hofmann, H.; Choi, K.S.; Singh, R.K. Synthesis of microporous silica spheres. J. Colloid Interface Sci. 2000, 227, 302-315. [CrossRef]

168. Jang, J.H.; Lim, H.B. Characterization and analytical application of surface modified magnetic nanoparticles. Microchem. J. 2010, 94, 148-158. [CrossRef]

169. Briso, A.; Quintana, G.; Ide, V.; Basualto, C.; Molina, L.; Montes, G.; Valenzuela, F. Integrated use of magnetic nanostructured calcium silicate hydrate and magnetic manganese dioxide adsorbents for remediation of an acidic mine water. J. Water. Process. Eng. 2018, 25, 247-257. [CrossRef]

170. Carné-Sánchez, A.; Imaz, I.; Cano-Sarabia, M.; Maspoch, D. A spray-drying strategy for synthesis of nanoscale metal-organic frameworks and their assembly into hollow superstructures. Nat. Chem. 2013, 5, 203-211. [CrossRef]

171. Qiao, K.; Tian, W.; Bai, J.; Wang, L.; Zhao, J.; Du, Z.; Gong, X. Application of magnetic adsorbents based on iron oxide nanoparticles for oil spill remediation: A review. J. Taiwan Inst. Chem. Eng. 2019, 97, 227-236. [CrossRef]

172. Oladipo, A.A.; Gazi, M. Efficient boron abstraction using honeycomb-like porous magnetic hybrids: Assessment of technoeconomic recovery of boric acid. J. Environ. Manage. 2016, 183, 917-924. [CrossRef] [PubMed]

173. Meng, F.; Yang, B.; Wang, B.; Duan, S.; Chen, Z.; Ma, W. Novel dendrimerlike magnetic biosorbent based on modified orange peel waste: Adsorption-reduction behavior of arsenic. ACS Sustain. Chem. Eng. 2017, 5, 9692-9700. [CrossRef]

174. Kong, L.; Yan, L.; Qu, Z.; Yana, N.; Li, L. $\beta$-Cyclodextrin stabilized magnetic $\mathrm{Fe}_{3} \mathrm{~S}_{4}$ nanoparticles for efficient removal of Pb(II). J. Mater. Chem. A 2015, 3, 15755-15763. [CrossRef]

175. Gong, Y.; Gai, L.; Tang, J.; Fu, J.; Wang, Q.; Zeng, E.Y. Reduction of Cr(VI) in simulated groundwater by FeS-coated ironmagnetic nanoparticles. Sci. Total Environ. 2017, 595, 743-751. [CrossRef]

176. Adel, M.; Ahmed, M.A.; Mohamed, A.A. Effective removal of indigo carmine dye from wastewaters by adsorption onto mesoporous magnesium nanoparticles. Environ. Nanotechnol. Monit. Manag. 2021, 16, 100550. [CrossRef]

177. Vergis, B.R.; Hari Krishna, R.; Kottam, N.; Nagabhushana, B.M.; Sharath, R.; Darukaprasad, B. Removal of malachite green from aqueous solution by magnetic $\mathrm{CuFe}_{2} \mathrm{O}_{4}$ nano-adsorbent synthesized by one pot solution combustion method. J. Nanostruct. Chem. 2018, 8, 1-12. [CrossRef]

178. Stan, M.; Lung, I.; Soran, M.-L.; Opris, O.; Leostean, C.; Popa, A.; Copaciu, F.; Lazar, M.D.; Kacso, I.; Silipas, T.-D.; et al Starch-Coated green synthesized magnetite nanoparticles for removal of textile dye Optilan blue from aqueous media. J. Taiwan Inst. Chem. Eng. 2019, 100, 65-73. [CrossRef]

179. Cao, Z.; Liu, X.; Xu, J.; Zhang, J.; Yang, Y.; Zhou, J.; Xu, X.; Lowry, G.V. Removal of antibiotic florfenicol by sulfide-modified nanoscale zero-valent iron. Environ. Sci. Technol. 2017, 51, 11269-11277. [CrossRef]

180. Song, S.; Su, Y.; Adeleye, A.S.; Zhang, Y.; Zhou, X. Optimal design and characterization of sulfide-modified nanoscale zerovalent iron for diclofenac removal. Appl. Catal. B Environ. 2017, 201, 211-220. [CrossRef]

181. Wang, S.; Gao, B.; Li, Y.; Wan, Y.; Creamer, A.E. Sorption of arsenate onto magnetic iron-manganese (Fe-Mn) biochar composites. RSC Adv. 2015, 5, 67971-67978. [CrossRef]

182. Wang, S.; Gao, B.; Zimmerman, A.R.; Li, Y.; Ma, L.; Harris, W.G.; Migliaccio, K.W. Removal of arsenic by magnetic biochar prepared from pinewood and natural hematite. Bioresour. Technol. 2015, 175, 391-395. [CrossRef] [PubMed]

183. Li, Z.; Xu, S.; Xiao, G.; Qian, L.; Song, Y. Removal of hexavalent chromium from groundwater using sodium alginate dispersed nano zero-valent iron. J. Environ. Manage. 2019, 244, 33-39. [CrossRef] [PubMed]

184. Zhang, Z.; Wang, X.; Wang, Y.; Xia, S.; Chen, L.; Zhang, Y.; Zhao, J. Pb(II) removal from water using Fe-coated bamboo charcoal with the assistance of microwaves. I. Environ. Sci. 2013, 25, 1044-1053. [CrossRef]

185. Dong, X.; He, L.; Hu, H.; Liu, N.; Gao, S.; Piao, Y. Removal of $17 \beta$-estradiol by using highly adsorptive magnetic biochar nanoparticles from aqueous solution. Chem. Eng. J. 2018, 352, 371-379. [CrossRef]

186. Sun, Q.; Tang, M.; Hendriksen, P.V.; Chen, B. Biotemplated fabrication of a $3 \mathrm{D}$ hierarchical structure of magnetic $\mathrm{ZnFe} 2 \mathrm{O}_{4} / \mathrm{MgAl}_{-}$ LDH for efficient elimination of dye from water. J. Alloys Compd. 2020, 829, 154552. [CrossRef]

187. Muntean, S.G.; Nistor, M.A.; Ianoș, R.; Păcurariu, C.; Căpraru, A.; Surdu, V.A. Combustion synthesis of $\mathrm{Fe}_{3} \mathrm{O}_{4} / \mathrm{Ag} / \mathrm{C}$ nanocomposite and application for dyes removal from multicomponent systems. Appl. Surf. Sci. 2019, 481, 825-837. [CrossRef]

188. Nistor, M.A.; Muntean, S.G.; Ianos, R.; Racoviceanu, R.; Ianași, C.; Cseh, L. Adsorption of anionic dyes from wastewater onto magnetic nanocomposite powders synthesized by combustion method. Appl. Sci. 2021, 11, 9236. [CrossRef]

189. Ianoş, R.; Păcurariu, C.; Muntean, S.G.; Muntean, E.; Nistor, M.A.; Nižňanský, D. Combustion synthesis of iron oxide/carbon nanocomposites, efficient adsorbents for anionic and cationic dyes removal from wastewaters. J. Alloys Compd. 2018, 741, 1235-1246. [CrossRef]

190. Mahmoodi, M.; Javanbakht, V. Fabrication of Zn-based magnetic zeolitic imidazolate framework bionanocomposite using basil seed mucilage for removal of azo cationic and anionic dyes from aqueous solution. Int. J. Biol. Macromol. 2021, 167, 1076-1090. [CrossRef]

191. Zhao, W.; Chen, Y.; Zhang, W. Rapid and convenient removal of fluoride by magnetic magnesium-aluminum-lanthanum composite: Synthesis, performance and mechanism. Asia-Pac. J. Chem. Eng. 2017, 12, 640-650. [CrossRef]

192. Jin, J.; Huang, X.; Zhou, L.; Peng, J.; Wang, Y. In situ preparation of magnetic chitosan resins functionalized with triethylenetetramine for the adsorption of uranyl(II) ions. J. Radioanal. Nucl. Chem. 2015, 303, 797-806. [CrossRef] 
193. Zhang, H.; Huang, F.; Liu, D.L.; Shi, P. Highly efficient removal of $\mathrm{Cr}(\mathrm{VI})$ from wastewater via adsorption with novel magnetic $\mathrm{Fe}_{3} \mathrm{O}_{4} @ \mathrm{C} @ \mathrm{MgAl}$-layered double-hydroxide. Chin. Chem. Lett. 2015, 26, 1137-1143. [CrossRef]

194. Fan, Y.; Yang, R.; Lei, Z.; Liu, N.; Lv, J.; Zhai, S.; Zhai, B.; Wang, L. Removal of Cr(VI) from aqueous solution by rice husk derived magnetic sorbents. Korean J. Chem. Eng. 2016, 33, 1416-1424. [CrossRef]

195. Chen, Y.; Xu, F.; Li, H.; Li, Y.; Liu, Y.; Chen, Y.; Li, M.; Li, L.; Jiang, H.; Chen, L. Simple hydrothermal synthesis of magnetic $\mathrm{MnFe}_{2} \mathrm{O}_{4}$-sludge biochar composites for removal of aqueous $\mathrm{Pb}^{2+}$. J. Anal. Appl. Pyrolysis 2021, 156, 105173. [CrossRef]

196. Elessawy, N.A.; El-Sayed, E.M.; Ali, S.; Elkady, M.F.; Elnouby, M.; Hamad, H.A. One-Pot green synthesis of magnetic fullerene nanocomposite for adsorption characteristics. J. Water Process. Eng. 2020, 34, 101047. [CrossRef]

197. Mirshahghassemi, S.; Lead, J.R. Oil recovery from water under environmentally relevant conditions using magnetic nanoparticles. Environ. Sci. Technol. 2015, 49, 11729-11736. [CrossRef]

198. Yan, W.; Lien, H.-L.; Koel, B.E.; Zhang, W. Iron nanoparticles for environmental clean-up: Recent developments and future outlook. Environ. Sci. Processes Impacts 2013, 15, 63-77. [CrossRef]

199. Su, Y.; Jassby, D.; Zhang, Y.; Keller, A.A.; Adeleye, A.S. Comparison of the colloidal stability, mobility, and performance of nanoscale zerovalent iron and sulfidated derivatives. J. Hazard. Mater. 2020, 396, 122691. [CrossRef]

200. Mangayayam, M.C.; Perez, J.P.H.; Dideriksen, K.; Freeman, H.M.; Bovet, N.; Benning, L.G.; Tobler, D.J. Structural transformation of sulfidized zerovalent iron and its impact on long-term reactivity. Environ. Sci. Nano 2019, 6, 3422-3430. [CrossRef]

201. Fan, D.; Johnson, G.O.; Tratnyek, P.G.; Johnson, R.L. Sulfidation of nano zerovalent iron (nZVI) for improved selectivity during iin-situ chemical reduction (ISCR). Environ. Sci. Technol. 2016, 50, 9558-9565. [CrossRef]

202. Garcia, A.N.; Boparai, H.K.; O'Carroll, D.M. Enhanced ichlorination of 1,2-dichloroethane by coupled nanoIron-dithionite treatment. Environ. Sci. Technol. 2016, 50, 5243-5251. [CrossRef] [PubMed]

203. Kefeni, K.K.; Mamba, B.B.; Msagati, T.A.M. Application of Spinel ferrite nanoparticles in water and wastewater treatment: A review. Sep. Purif. Technol. 2017, 118, 92-100. [CrossRef]

204. Tatarchuk, T.; Myslin, M.; Lapchuk, I.; Shyichuk, A.; Murthy, A.P.; Gargula, R.; Kurzydło, P.; Bogacz, B.F.; Pędzwiatr, A.T. Magnesium-Zinc ferrites as magnetic adsorbents for $\mathrm{Cr}(\mathrm{VI})$ and $\mathrm{Ni}(\mathrm{II})$ ion removal: Cation distribution and antistructure modeling. Chemosphere 2021, 270, 129414. [CrossRef] [PubMed]

205. Yan, H.; Zhang, J.; You, C.; Song, Z.; Yu, B.; Shen, Y. Influences of different synthesis conditions on properties of $\mathrm{Fe}_{3} \mathrm{O}_{4}$ nanoparticles. Mater. Chem. Phys. 2009, 113, 46-52. [CrossRef]

206. Vuong, T.K.O.; Tran, D.L.; Le, T.L.; Pham, D.V.; Pham, H.N.; Ngo, T.H.L.; Do, H.M.; Nguyen, X.P. Synthesis of high-magnetization and monodisperse $\mathrm{Fe}_{3} \mathrm{O}_{4}$ nanoparticles via thermal decomposition. Mater. Chem. Phys. 2015, 163, 537-544. [CrossRef]

207. Shen, Y.F.; Tang, J.; Nie, Z.H.; Wang, D.; Ren, Y.; Zuo, L. Preparation and application of magnetic $\mathrm{Fe}_{3} \mathrm{O}_{4}$ nanoparticles for wastewater purification. Sep. Purif. Technol. 2009, 68, 312-319. [CrossRef]

208. Xu, Z.; Shen, C.; Hou, Y.; Gao, H.; Sun, S. Oleylamine as both reducing agent and stabilizer in a facile synthesis of magnetite nanoparticles. Chem. Mater. 2009, 21, 1778-1780. [CrossRef]

209. Mohapatra, J.; Zeng, F.; Elkins, K.; Xing, M.; Ghimire, M.; Yoon, S.; Mishra, S.R.; Liu, J.P. Size-Dependent magnetic and inductive heating properties of $\mathrm{Fe}_{3} \mathrm{O}_{4}$ nanoparticles: Scaling laws across the superparamagnetic size. Phys. Chem. Chem. Phys. 2018, 20, 12879-12887. [CrossRef] [PubMed]

210. Liu, S.; Yu, B.; Wang, S.; Shen, Y.; Cong, H. Preparation, surface functionalization and application of $\mathrm{Fe}_{3} \mathrm{O}_{4}$ magnetic nanoparticles. Adv. Colloid Interface Sci. 2020, 281, 102165. [CrossRef]

211. Chin, S.F.; Pang, S.C.; Tan, C.H. Green synthesis of magnetite nanoparticles (via thermal decomposition method) with controllable size and shape. J. Mater. Environ. Sci. 2011, 2, 299-302.

212. Middea, A.; Spinelli, L.S.; Souza, F.G., Jr.; Neumann, R.; Fernandes, T.L.A.P.; Gomes, O.F.M. Preparation and characterization of an organo-palygorskite- $\mathrm{Fe}_{3} \mathrm{O}_{4}$ nanomaterial for removal of anionic dyes from wastewater. Appl. Clay Sci. 2017, 139, 45-53. [CrossRef]

213. Adeli, M.; Yamini, Y.; Faraji, M. Removal of copper, nickel and zinc by sodium dodecyl sulphate coated magnetite nanoparticles from water and wastewater samples. Arab. J. Chem. 2017, 10, S514-S521. [CrossRef]

214. Li, C.; Gao, Y.; Li, A.; Zhang, L.; Ji, G.; Zhu, K.; Wang, X.; Zhang, Y. Synergistic effects of anionic surfactants on adsorption of norfloxacin by magnetic biochar derived from furfural residue. Environ. Pollut. 2019, 254, 113005. [CrossRef] [PubMed]

215. Sotiriou, G.A.; Hirt, A.M.; Lozach, P.Y.; Teleki, A.; Krumeich, F.; Pratsinis, S.E. Hybrid, silica-coated, janus-like plasmonic-magnetic nanoparticles. Chem. Mater. 2011, 23, 1985-1992. [CrossRef] [PubMed]

216. Robinson, I.; Tung, L.D.; Maenosono, S.; Wältid, C.; Thanh, N.T.K. Synthesis of core-shell gold coated magnetic nanoparticles and their interaction with thiolated DNA. Nanoscale 2010, 2, 2624-2630. [CrossRef] [PubMed]

217. Kralj, S.; Drofenik, M.; Makovec, D. Controlled surface functionalization of silica-coated magnetic nanoparticles with terminal amino and carboxyl groups. J. Nanopart. Res. 2011, 13, 2829-2841. [CrossRef]

218. Cendrowski, K.; Sikora, P.; Zielinska, B.; Horszczaruk, E.; Mijowska, E. Chemical and thermal stability of core-shelled magnetite nanoparticles and solid silica. Appl. Surf. Sci. 2017, 407, 391-397. [CrossRef]

219. Chai, L.; Wang, Y.; Zhao, N.; Yang, W.; You, X. Sulfate-Doped $\mathrm{Fe}_{3} \mathrm{O}_{4} / \mathrm{Al}_{2} \mathrm{O}_{3}$ nanoparticles as a novel adsorbent for fluoride removal from drinking water. Water Res. 2013, 47, 4040-4049. [CrossRef] 
220. Sebastian, A.; Nangia, A.; Prasad, M.N.V. A green synthetic route to phenolics fabricated magnetite nanoparticles from coconut husk extract implications to treat metal contaminated water and heavy metal stress in Oryza sativa L. J. Clean. Prod. 2018, 174, 355-366. [CrossRef]

221. Ehrampoush, M.H.; Miria, M.; Salmani, M.H.; Mahvi, A.H. Cadmium removal from aqueous solution by green synthesis iron oxide nanoparticles with tangerine peel extract. J. Environ. Health Sci. Eng. 2015, 13, 84-366. [CrossRef] [PubMed]

222. Ren, G.; Yang, L.; Zhang, Z.; Zhong, B.; Yang, X.; Wang, X. A new green synthesis of porous magnetite nanoparticles from waste ferrous sulfate by solid-phase reduction reaction. J. Alloys Compd. 2017, 710, 875-879. [CrossRef]

223. Li, Y.; Zimmerman, A.R.; He, F.; Chen, J.; Han, L.; Chen, H.; Hu, X.; Gao, B. Solvent-Free synthesis of magnetic biochar and activated carbon through ball-mill extrusion with $\mathrm{Fe}_{3} \mathrm{O}_{4}$ nanoparticles for enhancing adsorption of methylene blue. Sci. Total Environ. 2020, 722, 137972. [CrossRef]

224. Minitha, C.R.; Suresh, R.; Maity, U.K.; Holdorai, Y.; Subramaniam, V.; Manoravi, P.; Joseph, M.; Kumar, R.T.R. Magnetite nanoparticle decorated reduced graphene oxide composite as an efficient and recoverable adsorbent for the removal of cesium and strontium ions. Ind. Eng. Chem. Res. 2018, 57, 1225-1232. [CrossRef]

225. Wen, W.; Wu, J.M. Nanomaterials via solution combustion synthesis: A step nearer to controllability. RSC Adv. 2014, 4, 58090-58100. [CrossRef]

226. Varma, A.; Mukasyan, A.S.; Rogachev, A.S.; Manukyan, K.V. Solution combustion synthesis of nanoscale materials. Chem. Rev. 2016, 116, 14493-14586. [CrossRef]

227. Wang, X.; Qin, M.; Fang, F.; Jia, B.; Wu, H.; Qu, X.; Volinsky, A.A. Effect of glycine on one-step solution combustion synthesis of magnetite nanoparticles. J. Alloys Compd. 2017, 719, 288-295. [CrossRef]

228. Aali, H.; Mollazadeh, S.; Vahdati Khaki, J. Single-phase magnetite with high saturation magnetization synthesized via modified solution combustion synthesis procedure. Ceram. Int. 2018, 44, 20267-20274. [CrossRef]

229. Zhang, D.; Qiu, J.; Shi, L.; Liu, Y.; Pan, B.; Xing, B. The mechanisms and environmental implications of engineered nanoparticles dispersion. Sci. Total Environ. 2020, 722, 137781. [CrossRef]

230. Cirtiu, C.M.; Raychoudhury, T.; Ghoshal, S.; Moores, A. Systematic comparison of the size, surface characteristics and colloidal stability of zero valent iron nanoparticles pre- and post-grafted with common polymers. Colloids Surf. A Physicochem. Eng. Asp. 2011, 390, 95-104. [CrossRef]

231. Park, Y.; Huh, C.; Ok, J.; Cho, H. One-Step synthesis and functionalization of high-salinity-tolerant magnetite nanoparticles with sulfonated phenolic resin. Langmuir 2019, 35, 8769-8775. [CrossRef]

232. Liu, J.; Dai, C.; Hu, Y. Aqueous aggregation behavior of citric acid coated magnetite nanoparticles: Effects of $\mathrm{pH}$, cations, anions, and humic acid. Environ. Res. 2018, 161, 49-60. [CrossRef]

233. Mohan, D.; Sarswat, A.; Ok, Y.S.; Pittman, C.U., Jr. Organic and inorganic contaminants removal from water with biochar, a renewable, low cost and sustainable adsorbent-A critical review. Bioresour. Technol. 2014, 160, 191-202. [CrossRef]

234. Thines, K.R.; Abdullah, E.C.; Mubarak, N.M.; Ruthiraan, M. Synthesis of magnetic biochar from agricultural waste biomass to enhancing route for waste water and polymer application: A review. Renew. Sustain. Energ. Rev. 2017, 67, 257-276. [CrossRef]

235. Wang, S.; Tang, Y.; Chen, C.; Wu, J.; Huang, Z.; Mo, Y.; Zhang, K.; Chen, J. Regeneration of magnetic biochar derived from eucalyptus leaf residue for lead(II) removal. Bioresour. Technol. 2015, 186, 360-364. [CrossRef]

236. Park, J.-H.; Ok, Y.S.; Kim, S.-H.; Cho, J.-H.; Heo, J.-S.; Delaune, R.D.; Seo, D.-C. Competitive adsorption of heavy metals onto sesame straw biochar in aqueous solutions. Chemosphere 2016, 142, 77-83. [CrossRef]

237. Cai, Y.; Yan, Z.-H.; Wang, N.-Y.; Cai, Q.-Y.; Yao, S.-Z. Preparation of naphthyl functionalized magnetic nanoparticles for extraction of polycyclic aromatic hydrocarbons from river waters. RSC Adv. 2015, 5, 56189-56197. [CrossRef]

238. Yu, J.; Zhu, S.; Pang, L.; Chen, P.; Zhu, G.-T. Porphyrin-Based magnetic nanocomposites for efficient extraction of polycyclic aromatic hydrocarbons from water samples. J. Chromatogr. A 2018, 1540, 1-10. [CrossRef]

239. Chen, Y.; Zhang, W.; Zhang, Y.; Deng, Z.; Zhao, W.; Du, H.; Ma, Z.; Yin, D.; Xie, F.; Chen, Y.; et al. In situ preparation of core-shell magnetic porous aromatic framework nanoparticles for mixed-mode solid-phase extraction of trace multitarget analytes. $J$. Chromatogr. A 2018, 1556, 1-9. [CrossRef]

240. Meng, C.; Zhikun, Z.; Qiang, L.; Chunling, L.; Shuangqing, S.; Songqing, H. Preparation of amino-functionalized $\mathrm{Fe}_{3} \mathrm{O}_{4} @ \mathrm{mSiO}_{2}$ core-shell magnetic nanoparticles and their application for aqueo us $\mathrm{Fe}^{3+}$ removal. J. Hazard. Mater. 2018, 341, 198-206. [CrossRef]

241. Santhosh, C.; Nivetha, R.; Kollu, P.; Srivastava, V.; Sillanpää, M.; Grace, A.N.; Bhatnagar, A. Removal of cationic and anionic heavy metals from water by 1D and 2D-carbon structures decorated with magnetic nanoparticles. Sci. Rep. 2017, 7, 14107. [CrossRef]

242. Zhou, Q.; Lei, M.; Li, J.; Zhao, K.; Liu, Y. Determination of 1-naphthol and 2-naphthol from environmental waters by magnetic solid phase extraction with Fe@MgAl-layered double hydroxides nanoparticles as the adsorbents prior to high performance liquid chromatography. J. Chromatogr. A 2016, 1441, 1-7. [CrossRef]

243. Yan, R.; Feng, X.; Kong, L.; Wan, Q.; Zheng, W.; Hagio, T.; Ichino, R.; Cao, X.; Li, L. Evenly distribution of amorphous iron sulfides on reconstructed $\mathrm{Mg}$-Al hydrotalcites for improving Cr(VI) removal efficiency. Chem. Eng. J. 2021, 417, 129228. [CrossRef]

244. Naing, N.N.; Li, S.F.Y.; Lee, H.K. Magnetic micro-solid-phase-extraction of polycyclic aromatic hydrocarbons in water. J. Chromatogr. A 2016, 1441, 23-30. [CrossRef]

245. Cai, Y.; Yan, Z.; Wang, L.; Van, M.N.; Cai, Q. Magnetic solid phase extraction and static headspace gas chromatography-mass spectrometry method for the analysis of polycyclic aromatic hydrocarbons. J. Chromatogr. A 2016, 1429, 97-106. [CrossRef] 
246. Verma, L.; Siddique, M.A.; Singh, J.; Bharagava, R.N. As(III) and As(V) removal by using iron impregnated biosorbents derived from waste biomass of Citrus limmeta (peel and pulp) from the aqueous solution and ground water. J. Environ. Manag. 2019, 250, 109452. [CrossRef]

247. Hari Prasad Rao, P.R.; Matsukata, M. Dry-Gel conversion technique for synthesis of zeolite BEA. Chem. Commun. 1996, 12, $1441-1442$

248. Xu, W.; Dong, J.; Li, J.; Li, J.; Wu, F. A novel method for the preparation of zeolite ZSM-5. J. Chem. Soc. Chem. Commun. 1990, 10, 755-756. [CrossRef]

249. Aono, H.; Tamura, K.; Johan, E.; Yamauchi, R.; Yamamoto, T.; Matsue, N.; Henmi, T. Preparation of composite material of Na-P1-type zeolite and magnetite for Cs decontamination. Chem. Lett. 2013, 42, 589591. [CrossRef] 